\title{
GEOLOGIA ESTRUTURAL DO EMBASAMENTO CRISTALINO NA REGIÃO DE SÃO SEBASTIÃO, SP: EVIDÊNCIAS DE UM DOMÍNIO TRANSPRESSIVO
}

\section{CRISTINA DE QUEIROZ TELLES MAFFRA}

Orientador: Prof. Dr. Ginaldo Ademar da Cruz Campanha

DISSERTAÇÃO DE MESTRADO

COMISSÃO JULGADORA

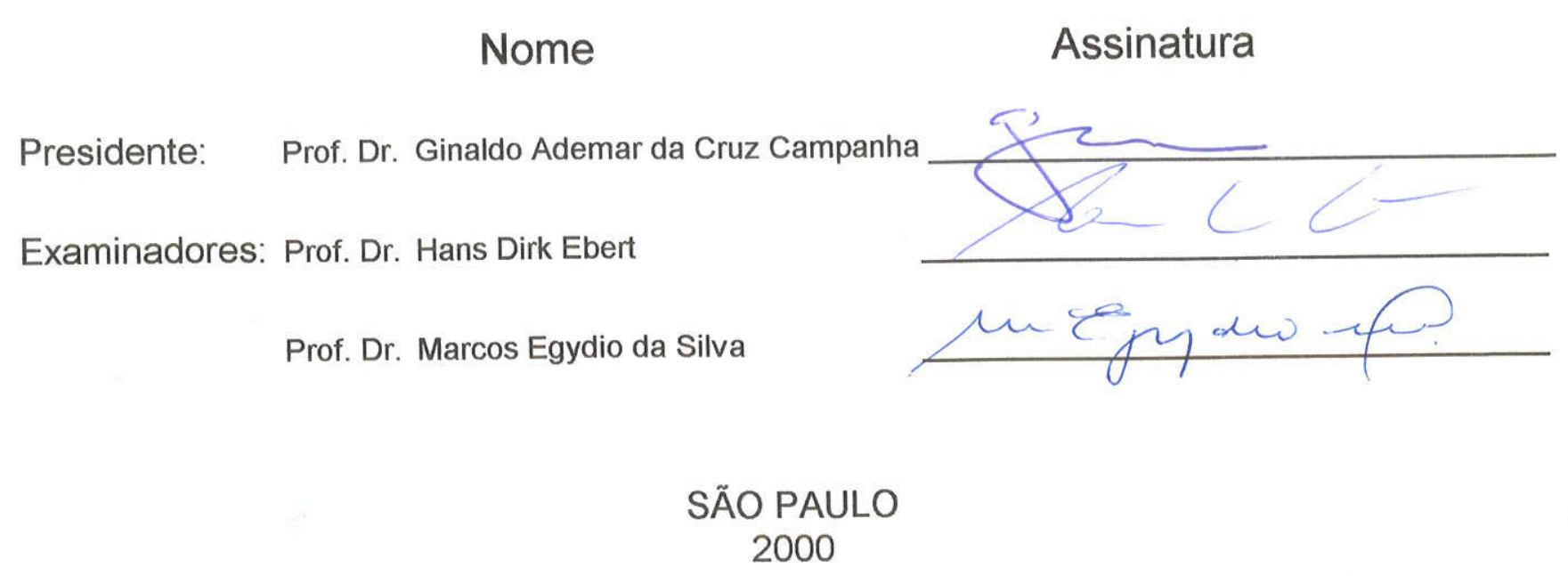




\title{
Universidade de São Paulo INSTITUTO DE GEOCIÊNCIAS
}

\section{Geologia Estrutural do Embasamento Cristalino NA REGIÃo de SÃo SEBASTIÃo, SP: EVIIÊNCIAS DE UM DOMÍNIO TRANSPRESSIVO}

\author{
Cristina de Queiroz Telles Maffra
}

Orientador: Prof. Dr. Ginaldo Ademar da Cruz Campanha

\section{DiSSERTAÇÃO DE MESTRAdO}

Programa de Pós - Graduação em Geoquímica e Geotectônica

$$
\text { SÃO PAULO }
$$

2000

DEDALUS - Acervo - IGC

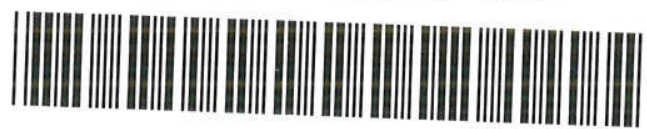

30900004365 
A meus pais Lúcia e Walter A meu avô Arthur (in memorian) 


\section{AGRADECIMENTOS}

Durante a realização desta dissertação contei com a colaboração de muitas pessoas, das mais variadas formas. Gostaria agora de poder agradecer -1 los.

Gostaria de agradecer inicialmente a meu orientador, Prof. Dr. Ginaldo A. da C. Campanha, por sua dedicação e paciência durante todas as fases de elaboração deste trabalho.

Meus agradecimentos também ao meu supervisor no International Institute of Aerospace Survey and Earth Sciences (ITC), Dr. Ernst Schetselaar.

Agradecimentos especiais ao Instituto Geológico que me forneceu toda infra-estrutura durante todo o período de realização da dissertação e permitiu minha estada no ITC.

Também por fornecer inframestrutura durante o periodo de trabalhos de campo, agradeço muito ao CEBIMAR (Centro de Biologia Marinha da USP).

Aos funcionários do Instituto de Geociências da USP, por sua valiosa prestação.

Aos meu colegas do IG que de diversas formas ajudaram, incentivaram e participaram deste trabalho.

Aos amigos cultivados durante minha estadia na Holanda, agradeço imensamente o apoio e o carinho, durante esse, que foi um período muito especial.

Aos meus colegas de turma por entender os diversos "canos" dados por mim, durante o período de realização deste trabalho. 
Agradecimentos especiais a Ciro pelo incentivo e indiscutível presença.

A meus pais devo agradecimentos eternos, pelo irrestrito apoio e pelo sempre carinho...

A meu avô Arthur que no decorrer de seu 92 anos foi um contínuo exemplo de simplicidade, integridade e ternura...

A todos, meus sinceros agradecimentos. 


\section{SUMÁRIO}

\section{RESUMO}

\section{ABSTRACT}

\section{CAPítulo 1 - InTROduç̃o}

1.1. DEFINIÇÃO DO PROBLEMA

1.2 OBJETIVOS 2

1.3 LOCALIZAÇÃO E ACESSOS

1.4 ASPECTOS FISIOGRÁFICOS 4

1.5 MÉTODO 5

1.6 MATERIAL DISPONIVEL

1.6.1 Mapas

1.6.2 Fotografias aéreas e Imagem de Radar

1.7 ESTRUTURAÇÃO DA DISSERTAÇÃOO

\section{CAPÍtulo 2 - Geologia Regronal}

2.1 INTRODUÇÃO 10

2.2 TRABALHOS ANTERIORES

2.2.I Análise da Deformą̧ão Regional - Histórico

2.2.2 A concepção atual

2.3 O CICLO BRASILIANO 18

2.4 O PADRÃO ESTRUTURAL REGIONAL 20

2.4.1 Trabalhos Anteriores

2.4.2 Perfil Regional Esquemático

\section{CAPÍtULO 3 - INTERPRETAÇÃO DA IMAGEM DO SATCLLTE DE RADAR} EUROPEU ERS- 1

3.1 INTRODUÇÃO 26

3.2 IMAGEM DO RADAR EUROPEU ERS-1 28

3.3 DISTORÇÕES RADIOMÉTRICAS E GEOMÉTRICAS EM SAR 29 
3.4 CORREÇÃO RADIOMÉTRICA 31

3.5 CORREÇÃO GEOMÉTRICA

3.6 REALCE DA IMAGEM 33

3.7 INTERPRETAÇÃO DA IMAGEM

CATITULO 4-DESCRICAODAS UNDDADES LTTOLOGICAS

4.1 INTRODUÇÃOO

4.2 Grantto Pico do Papagaio 44

4.3 AUGEN GANISSE JUQUEÍ 45

4.4 COMPLEXO GNÁISSICO MIGAMATITICO

4.5 GrantTO GUAECA $\quad 49$

4.4.1 Fácies Leucocrática com granada

4.4.2 Fácies a Biotita

4.6 METAMORFISMO

4.7 DIQUES 55

4.8 SEDIMENTOS NÃO CONSOLIDADOS 56

\section{CAPITULO 5-GeOLOGHA ESTRUTURAL.}

5.1 INTRODUÇÃOO

5.2 DOMínIO ESTRUTURAL 1: ZONA DE CISALHAMENTO DO BATRRO DO ALTO 62

5.3 DOMINIO ESTRUTURAL 2: ENTRE A ZONA dE CISAlHAMENTO ...

5.4 Domínio Estrutural 3: Zona de Cisalhamento Camburu 66

5.5 DOMínTo ESTRUTURAL 4: ENTRE A ZONA DE CISALHAMENTO... 71

5.6 Dominio Estrutural 5: Sistema de CaVAlgamento São SEbastião 74

5.7 ANÁLISE DA MACROESTRUTURA 80

\section{Capítulo 6 - Discussão e Conclusöes}

6.1 INTRODUÇÃO

6.2 TRANSPRESSÃO 83

6.3 COLOCAÇÃO DE GRANITOS EM REGIMES TRANSPRESSIVOS 86

6.4 ANÁlISE DAS ESTRUTURAS LOCAIS 92

6.5 RELAÇÕES GEOMÉTrICAS E MOdelos Propostos 96 
CAPÍTUlO 7-CONCLUSÕes 102

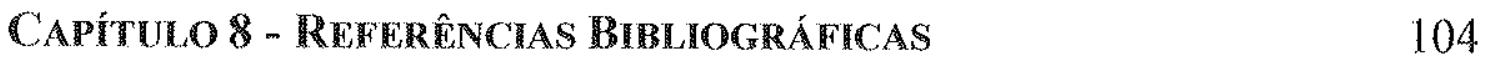
ANCXOI 


\section{INDICE DE FIGURAS}

\section{CAPITULO}

FIGURA 1.1 - LOCALIZAÇÃo da ÁREA dE ESTUdo

Figura 1.2 -.. ACEsso à Área de estudo

Figura 1.3 - Vista Geral da Área de estudo

\section{CAPÍTULO 2}

FIGURA 2.1 - OCORRÊNCIA DO COMPLEXO COSTEIRO

FIGURA 2.2 -- PERFLL REGIONAL ESQUEMÁTICO 21

FIGURA 2.3 -... PERFIL REGIONAL ESQUEMÁTICO

FIGURA 2.4 … PERFIS DETALHADOS DA ÁREA

Figura 2.5 -- PERFL GeOLÓgICO REGIONAL. 25

\section{CAPITULO 3}

FIGURA 3.1 - IMAGEM ERS-1 DA ÁREA DE ESTUdO 30

Figura 3.2

A: Imagem SAR original

B: Filtro Frost aprimorado $3 \times 3$

C: Filtro frost aprimorado $7 \times 7$

D: Filtro Gama $7 \times 7$

FIGURA 3.3 -.. IMAGEM SIMULADA SARSIM1

Figura 3.4 -- MOdElo Digrtal de ElevaÇão do Terreno 37

FIGURA 3.5 - IMAGEMERS - 1 APÓS TRATAMENTO 40

FIGURA 3.6 - INTERPRETAÇÃO DA IMAGEM ERS-1

\section{CAPITULOA}

FIGURA 4.1 - MAPA GEOLÓGICO GERAL.

Figura 4.2 -... Grantto Pico do Papagaio 44

FIGURA 4.3 -.. AUGEN GNAISSE JUQUEI

FIgURA 4.4-- SEÇÃo DELGAdA MIRMEqUITAS

FIGURA 4.5 -- SEÇÃo DELGAdA AUGEN GNAISSE

FIgURA 4.6 - COMPLEXO GNÁISSICO MigMATITICO, ESTRUTURA ESTROMÁTICA

FIGURA 4.7 - COMPLEXO GNÁISSICO MIGMATÍTICO, ESTRUTURA NEBULÍTICA

Figura 4.8 - GRANTTO GUAECA, FÁCIES LEUCOCRÁTICA

FigurA 4.9 -... GRANTTO GUAECÁ, FÁCIES A BIOTTTA 53

FIGURA 4.10 - DIAGRAMA P-T E SEÇ.̃o DELGADA. 


\section{CAPITULOLS}

FIGURA 5.1 -- MAPA DE DOMINIOS ESTRUTURAIS

FIgURA 5.2 -... ClasSIFICAÇÃo de PORFIROClastos

Figura 5.3 - Afloramento ZONA DE CISALHAMENTO BAIRRO dO Alto 63

FIGURA 5.4 - SEÇÃo DELGADA, RECRISTALIZAÇÃo DINÂMICA

FIGURA 5.5 -.- SEÇÃO DELGADA, S'TRIPPED GNEISS

FIGURA 5.6 -.. ESTEREOGRAMAS REFERENTES A Z.C. BAIRRO DO ALTO 65

FIGURA 5.7 - ESTEREOGRAMAS REFERENTES A ÁREA ENTRE AS ZONAS DE CISALHAMENTO 66

figura 5.8 - Estereogramas Zona de CISAlHAMENTO CAMBURU

FIGURA 5.9 - SEÇÃO DELGADA DO FABRIC MILONITICO DA ZONA 69

FIGURA $5.10 \ldots-70$

A: Estruturas $C / S$

B: Lineç̧ão de estiramento Z.C. Camburu

C: Porfiroclasto... sinistral, Z.C. Camburu

D: Porfiroclasto ... dextral, Z.C. Camburu

Figura 5.11 - Seção Delgada, Augen Gnaisse JuQue $\quad 72$

FIGURA 5.12 - ESTRUTURA PINCH - AND - SWELL. 73

FIGURA 5.13 -. 75

A:

$B:$

C:

D:

FIGURA 5.14 - DOBRAS INTRAFOLIAIS

FIGURA 5.15 --.- ESTEREOGRAMAS DO PRIMEIRO CAVALGAMENTO DO SISTEMA

FIGURA 5.16 - ESTEREOGRAMA DO SEGUNDO CAVALGAMENTO DO SISTEMA

FIGURA 5.17 ..- ESTEREOGRAMA DAS DOBRAS EM BAINKA

FIGURA 5.18 -.- ESTEREOGRAMA DAS: $\quad 80$

A: Foliação da área total

B: Lineação da área total

\section{CAPITULOOG}

FIGURA 6.1 - GEOMETRIA DE UMA ZONA...

FIGURA 6.2 -... MODELAGEM DE SANDERSON \&

FIGURA 6.3 - MODELO QUE RELACIONA ÂNGULO...

FIGURA 6.4 - ESTEREOGRAMAS INDICANDO VARIAÇÃO... 95

FIGURA 6.5 - MODELO PROPOSTO PARA ESTRUTURA EM FLOR POSITIVA ASSIMÉTRICA 100

FIGURA $6.6 \cdots$ FALHAS TRANSCORRENTES INDENTADAS 101 


\section{$\underline{\text { Resumo }}$}

O Complexo Costeiro estende-se ao longo da costa sudeste do Brasil e é composto por rochas gnáissico-migmatíticas de idade paleo - neoproterozóica. Faz parte do pelo Cinturão Ribeira, cuja origem pode ser associada ao Ciclo Brasiliano (700-530 Ma). Na área de estudo, no município de São Sebastião, litoral norte do Estado de São Paulo, estruturas associadas ao Cinturão Ribeira são expressas pela Zona de Cisalhamento Bairro Alto (ZCBA), Zona de Cisalhamento Camburu (ZCC) e pelo Sistema de Cavalgamento São Sebastião (SCSS). Trabalhos prévios sugerem que estas estruturas formam uma estrutura em flor positiva como resultado do caráter transpressivo do Cinturão Ribeira.

O escopo desta tese é estudar a deformação dúctil em São Sebastião a fïm de caracterizar as relações geométricas das estruturas principais, discutir os possíveis modelos para o arranjo estrutural e relacionar este arranjo ao contexto regional.

Este estudo incluiu cartografia estrutural, descrição de fabric, análise petrográfica, interpretação de imagem de radar, identificação de domínios litoestruturais e uma modelagem final.

Uma imagem de radar ERS-1 foi usada para ajudar na interpretação e caracterização estrutural regional. Inicialmente esta interpretação foi utilizada durante a fase de trabalhos de campo e mais tarde comparada as observações obtidas em campo. Sua interpretação mostrou a relação dos lineamentos principais e as estruturação regional, o caráter dextral da Zona de Cisalhamento Camburu indicado pela flexão dos lineamentos ao redor da zona.

A ocorrência de cavalgamentos em ambos os lados da Zona de Cisalhamento Camburu com vergência oposta, a foliação cujo padrão regional varia seu ângulo de mergulho (de subvertical nas zonas transcorrentes a suave nos cavalgamentos) e 
direção (de SE para NW), o padrão de lineação regional, a homogeneidade do metamorfismo ao longo de toda a área e a ausência de relações de sobreposição são fatos que apoiam a idéia de uma estrutura em flor para a área.

Porém um modelo que envolve Falhas Transcorrentes Indentadas (Indent -. liked Strike Slip Faults) como o resultado de uma colisão oblíqua responsável pela formação do sistema de cavalgamentos seguido pela implantação de zonas transcorrentes e "back thrust" também é satisfatório.

Dois corpos graníticos sin-tectônicos ocorrem na área: o Granito Pico do Papagaio e o Granito Guaecá.

Devido à foliação bem desenvolvida, paralela à foliação regional, a geometria alongada do corpo com o eixo maior paralelo a foliação regional, sua heterogeneidade composicional e seu "fabric" recristalizado, foi atribuído um caráter sintectônico ao Granito Guaecá com um forte componente de compressão presente na fase tardia de sua colocação.

Para o Granito Pico do Papagaio as evidências de uma colocação sintectônica não estão claras. A única relação clara é que este não corresponde a um plúton de colocação pós - tectônica pois apresenta faixa milonítica resultado da implantação da Zona de Cisalhamento Bairro do Alto.

A transpressão na região de São Sebastião é caracterizada por uma forte partição da deformação (strain) expressa pelo arranjo geométrico que envolve as principais estruturas da região. 


\section{Abstract}

The Complexo Costeiro is a basement complex that extends along the Southeast coast of Brazil and is composed by Paleo, Neo-Proterozoic gneissic-granitic rocks. It is part of the Ribeira Belt which origin is associated to the Brasiliano - Pan African orogeny (700-530 Ma) responsible for the assembly of this sector to the Gondwana super continent.

In the study area, at São Sebastião, São Paulo State, the Ribeira belt is expressed by the Bairro do Alto Transcurrent Shear Zone (BASZ), the Camburu Transcurrent Shear Zone (CSZ) and the São Sebastião Thrust System (SSTS). Previous works suggested that these structures form a flower structure as a result of the transpressive character of the Ribeira Belt.

The scope of this thesis is to study the ductile deformation in São Sebastião region in order to characterise the geometric relation among the main structures, to discuss the model compatible to the structural frame and relate them to the regional tectonic context.

This study included structural mapping, fabric description, petrographyc analysis, and identification of litho-structural domains, image interpretation and a final modelling.

An ERS-1 radar image was used to help in the regional structural interpretation and characterisation. It was initially used during fieldwork phase and afterwards compared with field observation. Its interpretation showed the relation of the main lineaments and the regional structures, the dextral character of the Camburu Shear Zone indicated by the flexure of lineaments around the zone. 
The occurrence of thrusts in both sides of the Camburu Shear Zone with opposite vengeance; the foliation regional pattern which shift in dip-angle (from subvertical in the transcurrent zones to gently in the thrust) and dip-direction (from SE to NW); the regional lineation pattern; the homogeneity of the metamorphism along the whole area and the absence of overprinting relations are facts that support the idea of a flower structure for the area.

But a model involving Indent -liked Strike Slip Faults as a result of a oblique collision responsible for the formation of the thrust system followed by the implantation of the transcurrent shear zones and a back thrust is also possible.

Two sin-tectonic granitic bodies occur in the area: the Pico do Papagaio and Guaecá Granites.

Due to the well developed foliation parallel to the regional foliation, the elongated geometry of the pluton with the largest axes parallel to the regional foliation, its compositional heterogeneity and the recrystallized fabric a syntectonic character is attributed to the Guaecá Granite with a strong compressional component present in a later stage of its emplacement.

For the Pico do Papagaio Granite syntectonic emplacement evidences are not clear. The only clear relation is that it does not correspond to a post tectonic pluton indicated by the wide mylonitic zone along the Bairro do Alto Shear Zone.

The transpression in São Sebastião region is characterised by strong partitioning of the strain. 
Capítulo 1 


\section{Capítulo 1: Introducão}

\section{1- Definicão do problema}

A geologia do embasamento cristalino do sudeste brasileiro apresenta uma trama estrutural na qual uma das feições mais proeminentes é a rede de zonas de cisalhamento transcorrentes, que se estende por mais de $1000 \mathrm{~km}$ ao longo da costa Atlântica. Este sistema de zonas de cisalhamento tem sua origem associada a evolução do Cinturão de Dobramentos Orogênico Ribeira, ligado à Orogênese Brasiliana - Pan - Africana $(700$ - $530 \mathrm{Ma})$, responsável pela amalgamação do Super Continente Gondwana. Esta orogenia gerou metamorfismo regional, intensa deformação dúctil e colocação de granitos sintectônicos.

Vários estudos realizados nos últimos anos sugerem um caráter transpressivo para a tectônica regional brasiliana.

Esta idéia é apoiada pela ocorrência de zonas dúcteis de cisalhamento com lineações de estiramento sub-horizontais e oblíquas, duplexes de cavalgamentos regionais, zonas de cisalhamento transcorrentes que delineiam estruturas em flor positivas em larga escala, com colocação de granitos sin-tectônicos.

A Zona de Cisalhamento Camburu (ZCC) é parte deste sistema. Afeta localmente litologias pertencentes ao Complexo Costeiro, uma seqüência granito gnáissica - migmatítica de idade proterozóica ainda não bem definida, com granitos neoproterozóicos a cambrianos.

Ao redor da ZCC a foliação regional tem uma distribuição em leque e este fato somado à ocorrência de cavalgamentos sugere um caráter transpressivo para a deformação dúctil da área (Campanha \& Ens, 1996). 
Esta dissertação enfoca a deformação dúctil da região de São Sebastião; estuda os lineamentos regionais; elementos lineares e planares, indicadores cinemáticos e variação do "fabric" utilizados para caracterizar a geometria estrutural.

A interpretação da imagem ERS-1 é usada para ajudar a identificação e caracterização do padrão estrutural regional.

Uma área de $800 \mathrm{~km}^{2}$ foi selecionada para estudar o fabric dúctil. Nesta área a distribuição em leque da foliação ao redor de uma zona de cisalhamento transcorrente combinada com cavalgamentos divergentes sugerem a ocorrência de uma estrutura em flor (Campanha; Ens \& Ponçano, 1994). Nesta dissertação maior detalhe foi realizado na borda leste desta estrutura, onde as condições de afloramento são melhores.

Embora esta estruturação tenha sido anteriormente sugerida, sua geometria ainda não foi estudada em detalhe.

Padrões de strain, relações de colocação de plútons graníticos e o padrão estrutural geral são tópicos que devem ser focalizados para que se possa entender a evolução estrutural da área de estudo. Eles não só são importantes para caracterizar a estrutura local mas também para se entender os processos envolvidos no regime transpressivo, desenvolvido durante o Ciclo Brasiliano no Sudeste Brasileiro.

\subsection{Objetivos}

O objetivo principal desta dissertação é estudar a deformação dúctil em uma área de $800 \mathrm{~km}^{2}$ no leste do Estado de São Paulo visando contribuir à caracterização estrutural desta área.

Mais especificamente pretende-se caracterizar a ocorrência de uma possível macroestrutura em flor positiva, sugerida em trabalhos anteriores. 
Um modelo final do regime de deformação é proposto e discutido, comparando os resultados obtidos com modelos propostos para colocações em regimes transpressivos.

\section{3- Localizacão e Acessos}

A área de estudo localiza - se na região sudeste do Brasil, no município de São Sebastião, litoral norte do Estado de São Paulo (figura 1.1).

O seu acesso a partir da cidade de São Paulo pode ser feito através da rodovia dos Imigrantes até o município de Cubatão, seguindo-se pela rodovia Piaçaguera até a cidade do Guarujá onde segue-se para norte através da Rodovia Rio - Santos (BR 101/ SP 55), que corta toda porção sul/sudeste da área de estudo. Outra possibilidade de acesso é através da Rodovia Ayrton Sena até a cidade de São José dos Campos seguindo pela Rodovia dos Tamoios (SP 99), até a cidade de Caraguatatuba onde então entra-se na Rodovia Rio - Santos rumo ao sul para a cidade de São Sebastião.

\section{São Paulo}

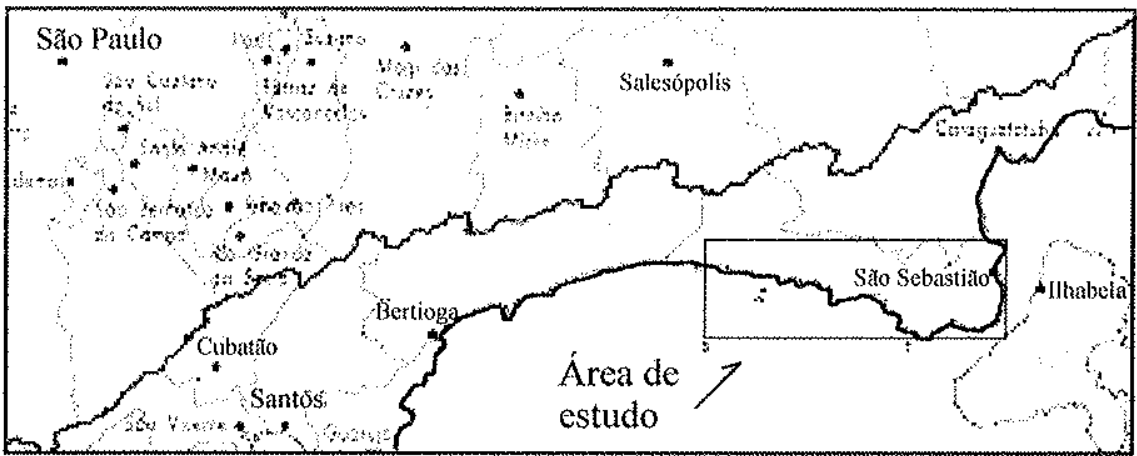

Área de
estudo 
A figura 1.2 ilustra o acesso à área de estudo.

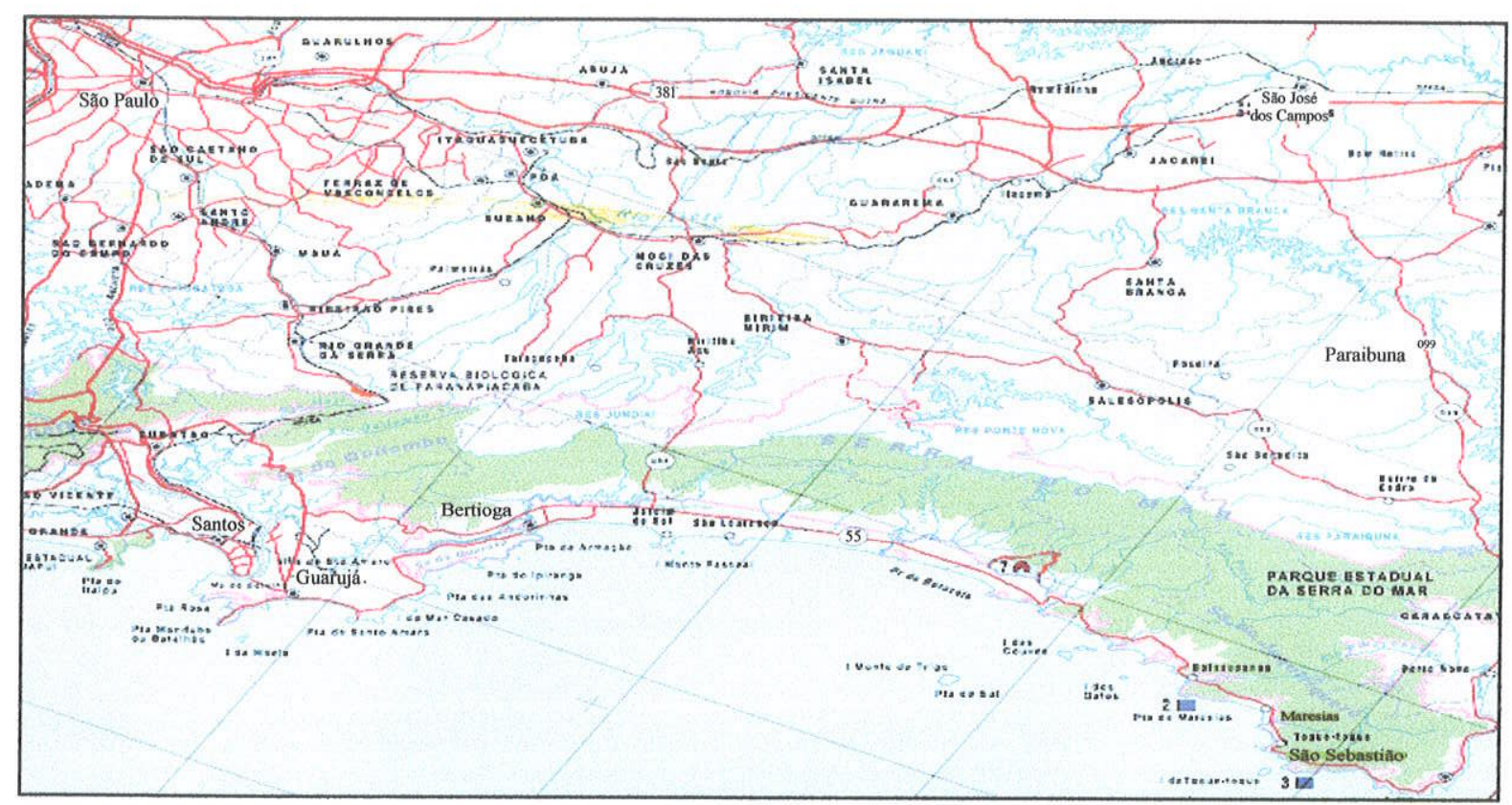

Figura 1.2 - Acesso à área de estudo.

\section{4 - Aspectos Fisiográficos}

Quanto aos aspectos fisiográficos que envolvem a área de estudo podemos dizer que regionalmente o clima é do tipo Tropical de Altitude com temperaturas que variam entre $18^{\circ}$ a $26^{\circ} \mathrm{C}$ e amplitude térmica entre $7^{\circ}$ a $9^{\circ} \mathrm{C}$. O clima é fortemente controlado pela ação da massa tropical marítima e pelas massas polares, principais responsáveis pelo regime de chuvas. O índice pluviométrico médio é elevado e atinge $4.000 \mathrm{~mm} /$ ano na região de Bertioga (Conti \& Furlan, 1998), sendo mais intenso durante o verão (dez/abril). Estas condições de clima são favoráveis para a formação de solo espesso.

A vegetação da costa do sudeste de Brasil é a Floresta Atlântica ou Floresta Litorânea que têm a mais alta biodiversidade por hectare no mundo. É uma floresta densa com árvores altas e vegetação rasteira densa. 
Em termos geomorfológicos regionais a costa sudeste brasileira é caracterizada pela existência de uma escarpa abrupta, a Serra do Mar. Sua formação é atribuída a eventos tectônicos que ocorreram durante o Cenozóico.

Regionalmente a área de estudo situa-se no domínio geomorfológico da Província Costeira, subdividida em duas zonas; a Serrania Costeira e as Baixadas Litorâneas (Ponçano et al., 1981).

Em termos de geomorfologia local no município de São Sebastião são reconhecidos relevos do tipo Morros e Morrotes de Planalto, Morros e Montanhas de Planalto, relevos associados a escarpa da Serra do Mar; Morros e Morrotes Litorâneos e Planícies Marinhas e Fluvio - Marinhas (Tominaga, 1995).

Uma importante feição na área de estudo são os planaltos interiores: Moraes, Juqueriquerê e Lourenço Velho. Eles representam uma sucessão separada por falhas normais resultantes de reativação de estruturas precambrianas durante o Cretáceo Inferior, Eoceno e Mioceno Inferior (Campanha, Ens \& Ponçano, 1994).

Nas unidades formadas pela escarpa que compõe a Serra do Mar, a declividade elevada favorece a formação de depósitos coluvionares e de tálus em sua base.

A figura 1.3 proporciona uma idéia geral da vegetação e morfologia locais.

\section{5-Método}

Os métodos empregados para a realização das investigações foram os que usualmente são utilizados em cartografia geológica de áreas precambrianas. Assim, a elaboração desta dissertação pode ser dividida em quatro fases distintas: preliminar, trabalhos de campo, análise e síntese final. 


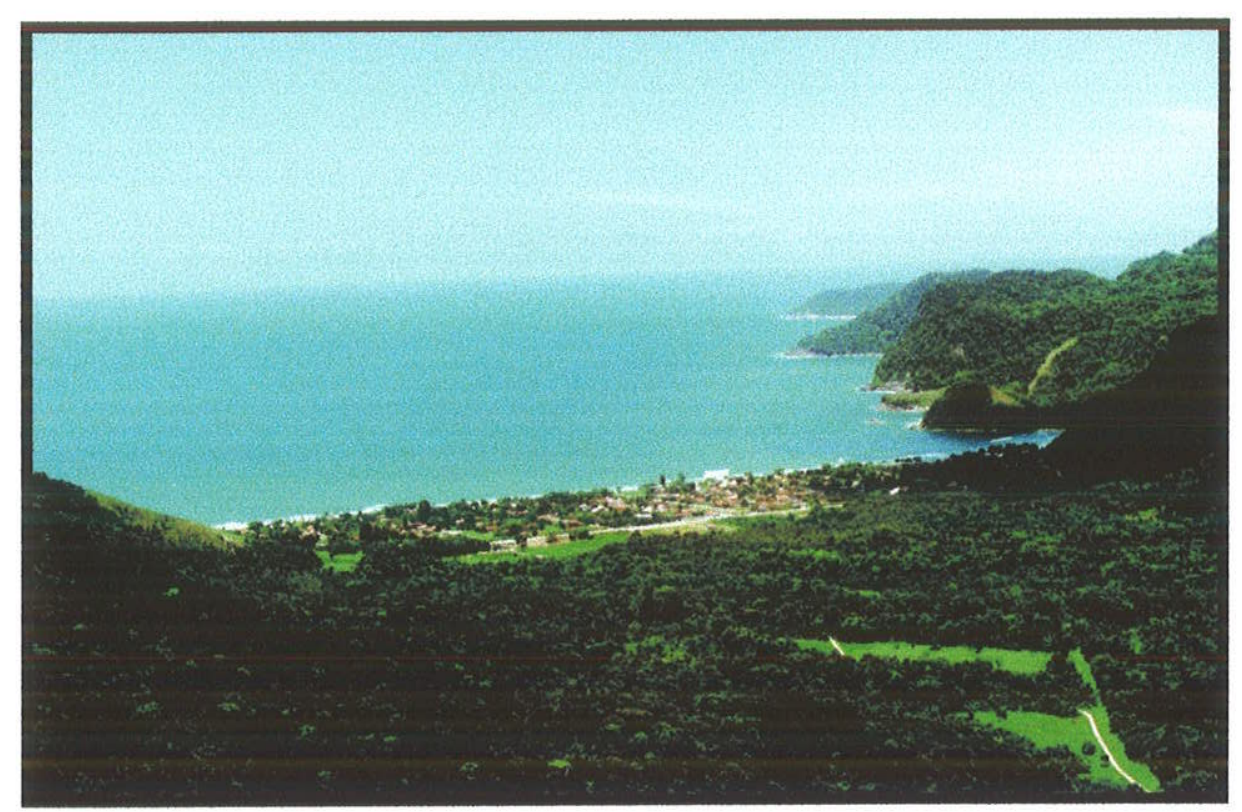

Figura 1.3 - Vista Geral da área de estudo. Percebe-se o relevo acidentado que compõem a Serra do Mar.

Durante a fase preliminar foi realizado um estudo bibliográfico sobre a área em estudo e os tópicos a serem desenvolvidos, sendo elaborado um mapa básico contendo informações topográficas, geológicas e estruturais existentes. Também foi feito o tratamento e a interpretação da imagem de radar ERS-1. Uma quarta parte desta imagem corresponde a área de estudo. Nesta parte da imagem foram feitas as correções radiométricas, geométricas e realce, a fim de se ampliar a interpretabilidade da imagem.

Durante a fase de trabalhos de campo realizou-se uma cartografia estrutural sistemática em escala 1:25.000 de parte da área de estudo onde foram feitas medidas sistemáticas de foliação, lineação, boudins, orientação de eixos de dobra, análise de indicadores cinemáticos, coleta de amostras orientadas e preparação de seções delgadas. 
A fase de análise incluiu descrição das seções delgadas e análise microestructural, análise de estereogramas e elaboração do mapa geológico.

A fase de síntese final incluiu a elaboração de um mapa contendo diferentes domínios lito-estruturais homogêneos e elaboração do modelo de evolução estrutural para a área.

Cabe salientar que parte das análises realizadas, principalmente aquelas referentes ao tratamento e análise da imagem de radar bem como elaboração e análise de seções delgadas foram realizadas no ITC (International Institute for Aerospace Survey and Earth Sciences) da Holanda.

\section{6 - Material Disponível}

\subsubsection{Mapas}

Neste trabalho foram utilizados os seguintes mapas:

- Mapas topográficos em escala 1:50.000, correspondendo aos números de folhas: SF-23-Y-D-V-2, SF-23-Y-D-V-4, SF-23-Y-D-VI-1, SF-23-Y-D-VI3, produzidos pelo IBGE (Instituto Brasileiro de Geografia e Estatísticas) em 1971 e 1986; mapas topográficos em escala 1:10.000 que corresponde aos números de folhas: SF-23-Y-D-V-1-SE-F, SF-23-Y-D-V-2-SO-E, SF-23-Y-DV-2-SO-F, SF-23-Y-D-V-2-SE-E, SF-23-Y-D-V-2-SE-F, SF-23-Y-D-VI-1-SOE, SF-23-Y-D-VI-1-SOmF, SF-23-Y-D-V-3-NEmA, SF-23-Y-D-V-3-NEmB, SF23-Y-D-V-4-NO-A, SF-23-Y-D-V-4-NO-B, SF-23-Y-D-V-4-NE-A, SF-23-YD-V-4-NE-B, SF-23-Y-D-VI-3-NO-A, SF-23-Y-D-VI-3-NO-B, SF-23-Y-D-V4-NE-C， SF-23-Y-D-V-4-NE-D， SF-23-Y-D-VI-3-NO-C， SF-23-Y-D-VI-3NO-D, SF-23-Y-D-VI-3-NO-E produzidos pela Coordenadoria de Ação Regional do Estado de São Paulo, em 1977; e uma base topográfica digitalizada em escala 1:25.000 pelo Instituto Geológico do Estado de São Paulo. 
- Mapa geológico em escala 1:50.000 produzida pelo Instituto Geológico de São Paulo em 1996 (IG/SMA, 1996), do qual a autora participou da elaboração.

\subsubsection{Fotografias Aéreas e Imagem de Radar}

- Fotografias aéreas da área em escala 1:60.000; 1:45.000 e 1:25.000.

- Imagem de radar ERS-1 SAR digital. Esta imagem cobre uma área de aproximadamente $160 \times 160 \mathrm{~km}$ e tem resolução de pixel de $12.5 \times 12.5 \mathrm{~m}$.

Além deste material, um jogo de trinta seções delgadas das litologias abrangentes foi confeccionado para ser feita a descrição das litologias presentes, seu metamorfismo e para o estudo microestrutural.

\section{7- Estruturacão da Dissertacão}

Capítulo 1 - Introduz a área, sua localização, os objetivos deste estudo como também o método utilizado e o material disponível durante a elaboração da dissertação.

Capítulo 2 - Descreve a geologia regional, proporciona uma breve visão das mais recentes interpretações para a estrutura regional, apresenta perfis regionais apresentados em trabahos anteriores e apresenta um perfil regional esquemático.

Capítulo 3 - Traz a interpretação de imagem de radar ERS-1.

Capítulo 4 - Apresenta a geologia local; descreve as unidades litológicas presentes na área de estudo.

Capítulo 5 - Referente a geologia local; descreve a geologia estrutural da área em estudo e provê uma análise estrutural detalhada da área em estudo. 
Capítulo 6 - Apresenta uma discussão baseada nos resultados obtidos e apresenta modelos que podem explicar estes resultados.

Capítulo 7 - Conclusões e considerações finais.

Capítulo 8 - Referências bibliográficas.

Anexo I - Mapa geológico em escala 1: 25.000. 
Capítulo 2 


\section{Capítulo 2: Geologia Regional}

\section{1-Introducão}

Esste capítulo provê uma descrição da geologia regional com a finalidade de situar a área de estudo em seu contexto regional.

A área de estudo faz parte do embasamento cristalino que ocorre ao longo da faixa litorânea do Estado de São Paulo, o qual é composto principalmente por rochas gnáissico-migmatíticas e metassedimentos associados de idade pré cambriana.

A primeira proposição estratigráfica para as rochas do litoral foi feita por Rego, 1933 (apud Hasui, Mioto \& Morales, 1994) que sugeriu reunir as rochas gnáissicas no Complexo Cristalino e as rochas metassedimentares na Série São Roque.

Posteriormente Ebert (1968) as inseriu no Grupo Paraíba.

Hasui \& Sadowski (1976) atribuíram as rochas mais antigas como pertencentes ao Complexo Piaçaguera e às mais jovens como pertencentes ao Grupo Açungui, que foi subdividido em porções não migmatizadas (Complexo Pilar) e porções migmatizadas (Complexo Embu).

Hasui et al., 1978 (apud Hasui, Mioto \& Morales, 1994) inseriu a zona costeira do Estado de São Paulo, no Maciço Mediano de Joinville, que apresentaria núcleos de granulitos, charnockitos, migmatitos e metabasitos pré-brasilianos envolvidos por migmatitos brasilianos.

Por fim, devido à dificuldade de se distinguir gnaisses e muitos migmatitos de idades diferentes situados a SE do falhamento de Cubatão, todas essas litologias foram englobadas no Complexo Costeiro, de idade Arqueana (Almeida et al., 1981). 
A área de estudo faz parte do Complexo Costeiro em sua porção pertencente ao Estado de São Paulo (figura 2.1).

A idéia geral é a existência de um embasamento mais antigo de idade transamazônica $(2.1$ - $1.8 \mathrm{Ga})$ e de supracrustais a ele sobrepostos e corpos graníticos intrusivos de idade brasiliana $(700-500 \mathrm{Ma})$.

O Complexo Costeiro, na área de estudo, é composto principalmente por uma sequência granito - gnáissica - migmatítica e por biotita gnaisses com granada.

A sequência de migmatitos é bem extensa na área. Trata-se de migmatitos com textura estromática, oftalmítica ou nebulítica com gerações diferentes de neossoma. Os neossomas dos migmatitos de textura estromática e oftalmítica têm composição cálcio-alcalina, são paralelos à xistosidade e são considerados mais antigos que os neossomas de composição alcalina, foliados ou não (Hasui \& Sadowski, 1976). O melanossoma é freqüentemente composto de biotita ou às vezes anfibólio.

Estes migmatitos também apresentam intercalações decimétricas de anfibolitos que correspondem a relictos de rochas básicas.

Outra característica importante é a presença de corpos de graníticos, colocados durante o Ciclo Brasiliano.

Vários corpos graníticos no Estado do Rio de Janeiro apresentam assembléia mineral compativel com granitos do tipo $\mathrm{S}$, resultado da anatexia de sequências metassedimentares (Machado \& Demange, 1991). Este fato é apoiado pela assembléia mineralógica deste granitóides e pela associação íntima entre eles e os migmatitos. Esta relação pode ser evidenciada pela ocorrência de contatos transicionais e difusos entre as duas litologias. 
Algum plútons discordantes que ocorrem na região de Cubatão, Estado de São Paulo, apresentam foliação incipiente e auréolas de contato sugerindo origem póstectônica (Hasui \& Sadowski, 1976).

Próximo à São Sebastião, o Complexo Costeiro é afetado por vários diques com orientação ENE. Trata-se de diques básicos e intermediários (diabásio e diorito) e lamprófiros com afinidade alcalina. De acordo com Garda (1995) os últimos tem origem mantélica distinta dos primeiros. Os diques de composição básica e intermédiária têm afinidade com os basaltos da Bacia do Paraná e poderiam ser gerados durante o processo da abertura de Oceano Atlântico. Os lamprófiros provavelmente são relacionados a um evento de magmatismo alcalino que teria ocorrido na área entre a intrusão dos diques básicos e intermediários (130 Ma) e a intrusão do Complexo Sienítico de Ilha Bela, de $80 \mathrm{Ma}$.

Sedimentos cenozóicos, pré-atuais e atuais, depositaram-se ao longo das planícies litorâneas. Trata-se, em geral, de sedimentos marinhos (arenitos e siltitos) mas, devido ao relevo de alta declividade, uma quantia considerável de depósitos continentais (principalmente depósitos de tálus e sedimentos coluvionares) e sedimentos mistos (marinho e continental) também ocorrem na área.

Como resultado desta grande diversidade litológica, controvérsias permanecem quanto a correlação entre o Complexo Costeiro e a estratigrafia regional.

No quadro tectônico regional a área de estudo situa-se no Cinturão Ribeira (Almeida et al., 1973 apud Almeida et al., 1981), denominação usada para uma unidade de idade brasiliana sobreposta ao Cinturão Paraíba do Sul, de idade transamazônica.

Estudos mais recentes interpretam o Cinturão Ribeira como um cinturão transpressivo. 


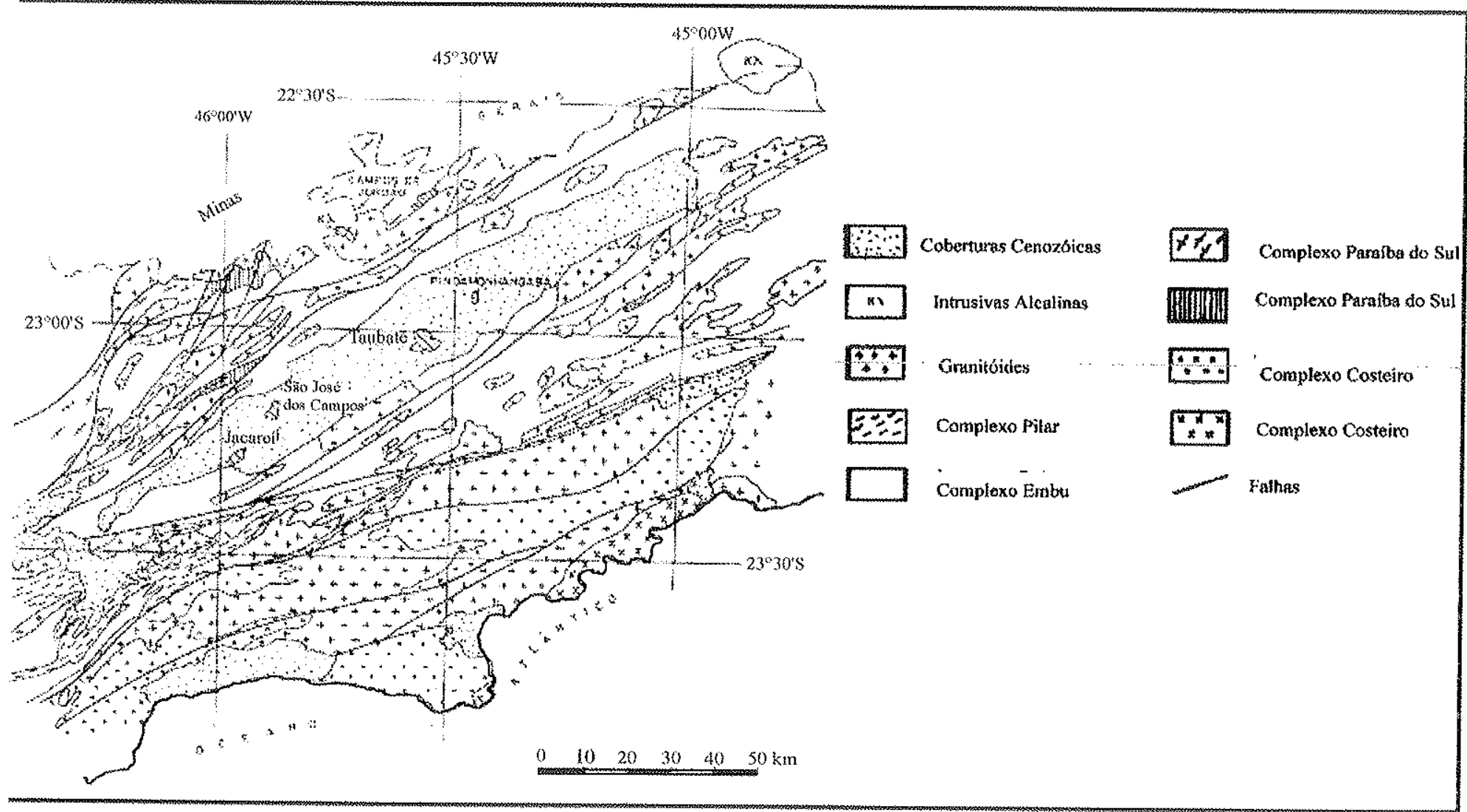

Figura 2.1 - Ocorrência do Complexo Costeiro no Estado de São Patlo. Modificado de Almeida et al. (1981).

\section{2- Trabalhos Anteriores}

A região que abrange o litoral paulista vem sendo alvo de estudos geológicos mais sistemáticos desde a década de 30 com trabalhos de Rego, 1933 e posteriormente Freitas, 1947 ( apud Hasui, Mioto \& Morales, 1994).

$\mathrm{Na}$ década de 70 mapeamentos em escala 1:100.000 foram feitos por Rideg (1974 apud Hasui, Mioto \& Morales, op. cit.); Melo \& Pires Neto (1977) ao longo do litoral e litoral norte e o projeto Sudelpa no litoral sul. É desta época também o projeto Santos-Iguape (CPRM,1977), que mapeou extensa área do litoral em escala $1: 250.000$. 
Trabalhos temáticos foram feitos por Sadowski (1974 e 1983), que estudou a Tectônica da Serra de Cubatão e os Cinturões de cisalhamento continentais.

$\mathrm{Na}$ década de 80 Chiodi et al. (1983) mapearam em escala 1:50.000 as folhas Natividade da Serra e Caraguatatuba.

Nos últimos anos inúmeros trabalhos de cunho geológico/ geotécnico vem sendo desenvolvidos em áreas do litoral paulista. Trata-se de estudos temáticos, muitos deles em escala regional, 1:250.000, visando a compartimentação ambiental e o planejamento regional.

Dentre estes trabalhos cabe ressaltar o projeto Macrozoneamento feito para o programa estadual de gerenciamento costeiro. Este projeto, que engloba todo o litoral paulista, foi desenvolvido com a finalidade de auxiliar na racionalização do uso dos recursos naturais costeiros. Através deste projeto foram geradas cartas geológica-geotécnicas na escala 1:50.000

\subsubsection{Análise da Deformação Regional-Histórico}

Ebert (1968) denominou Faixa Paraibides a região do Vale do Paraíba onde um eixo de divergência estrutural passaria, tendo as Serras da Mantiqueira e do Mar vergências opostas.

Posteriormente Almeida et al. (1973 apud Almeida et al., 1981) sugeriu a existência da Faixa de Dobramentos Paraíba do Sul, que seria um embasamento de idade transamazônica com processos brasilianos superpostos.

O Cinturão Ribeira, foi então definido como esta unidade de idade brasiliana sobreposta ao Cinturão Paraíba do Sul.

Hasui et al. (1975); Almeida et al. (1976) e Hasui et al. (1978) incluíram a presente área na Região de Dobramentos Sudeste, tida como uma sequência 
dobrada e metamorfizada de idade neoproterozóica, formada por faixas dobradas separadas por áreas de rochas mais antigas.

Outras denominações atribuídas a este cinturão orogênico foram: Cinturão Paraíba, de Cordani et al.(1968); Cinturão Atlântico, Fyfe \& Leonardos Jr. (1974); Lockzy \& Ladeira (1976); Província Mantiqueira, Almeida et al.(1981).

Trabalhos mais recentes de Ebert et al. (1993) e Machado \& Endo (1993), denominaram respectivamente Cinturão Transpressivo Paraíba do Sul e Cinturão de Cisalhamento Atlântico. Machado (1997) em seu trabalho de livre-docência, estabeleceu uma hierarquia para o Cinturão, com a existência de sistemas de cisalhamento de primeira ordem (Cinturão de Cisalhamento Atlântico), segunda ordem (como o Sistema de Cisalhamento Paraíba do Sul), e de terceira ordem (como no caso de zonas de cisalhamento Além -Paraíba- Cubatão).

No presente trabalho optou-se pela denominação de Cinturão Ribeira, dado seu caráter histórico. Porém o conceito aqui atribuido vem a luz das interpretações mais recentes.

\subsubsection{A concepesa}

Recentemente o Cinturão Ribeira tem sido reinterpretado como um cinturão transpressivo (Ebert et al., 1993; Fragoso Cesar, 1993; Machado \& Endo, 1993; Wiedemann, 1996).

Esta interpretação é favorecida pela ocorrência de zonas de cisalhamento dúcteis de alto ângulo, sistemas de cavalgamento, ocorrência de rochas de textura milonítica e associação de granitóides foliados à zonas de cisalhamento dúcteis (em escala regional), bem como dobras isoclinais, dobras em bainha e o comportamento oblíquo das estruturas lineares (em escala local). 
Trabalhos de Machado \& Endo (1993), Ebert et al. (1993), Ebert, Hasui \& Sena Costa (1991), Campanha \& Ens (1993), Campos Neto et al. (1993), Fassbinder (1996) indicam a existência de estruturas em flor ao longo de vários segmentos do cinturão, associadas às zonas de cisalhamento dúcteis de alto ângulo.

De acordo com Machado (1997) as estruturas em flor desempenham um papel importante na colocação de magmatismo granítico em regime transpressivo ao longo do cinturão.

Normalmente regimes transpressivos promovem o encurtamento e espessamento da crosta e a transferência de material da camadas inferiores da crosta para camadas medianas e superiores. Nesta situação mobilização de fluidos e fusão parcial são comuns ou, em outras palavras, plutonismo.

Ao longo do Cinturão Ribeira vários corpos graníticos foram mapeados. A geometria alongada desses corpos parece ser concordante com o regime transpressivo regional. Eles tendem a ocupar o plano $\mathrm{XZ}$ do elipsóide de deformação regional.

Os corpos graníticos que ocorrem ao longo do Cinturão Ribeira foram colocados predominantemente através de sheeting ou balonismo fraco (Molyneaux \& Ebert, 1997).

Sobre este tema cabe ressaltar os trabalhos de Wernick \& Töpfner (1997), Machado \& Endo (1993), e Figueiredo \& Campos Neto (1993).

O modelo tectônico mais aceito para explicar o magmatismo granítico do cinturão é o de subduç̧ão de crosta oceânica. Porém existem divergências quanto ao sentido de mergulho. Tassinari (1988) e Wernick (1990) acreditam que a vergência é para leste; Machado (1990), Machado \& Demange (1991), Campos Neto (1991), Figueiredo \& Campos Neto (1993) e Campos Neto \& Figueiredo 
(1995) atribuem vergência para NW e Fragoso Cesar (1993) atribue vergência para NW e SE.

A interpretação de um modelo transpressivo para o cinturão foi dada inicialmente por Ebert et al. (1993) e Machado \& Endo (1993). Para quem a transpressão foi resultado de uma colagem obliqua de terrenos.

Quanto às suas estruturas, o Cinturão Ribeira pode ser subdividido em três partes: uma porção interna onde predominam movimentos horizontais e zonas de cisalhamento transcorrentes de alto ângulo; uma porção intermediária com cavalgamentos e dobras e uma porção externa onde a deformação só afeta unidades supra-crustais.

Acredita-se que durante uma primeira fase foram formados os sistemas de cavalgamento e em uma segunda fase eles foram acomodados por zonas de cisalhamento transcorrentes (Ebert, Hasui \& Sena Costa, 1991). Estas estruturas evolúram em alguns segmentos do cinturão para duplexes direcionais e estruturas em flor (Ebert, Hasui \& Sena Costa, op.cit. ).

A existência de anomalia Bouguer na região de Bananal (no Estado do Rio de Janeiro) estendendo-se até a região de Ubatuba - Caraguatatuba e submergindo próximo a praia de Maresias (Estado de São Paulo), pode sugerir a ocorrência de uma discontinuidade crustal (Hasui et al., 1991).

Uma sutura é assumida na parte central do Cinturão Ribeira (Heilbron et al., 1996). Esta sutura pode ter sido gerada por uma junção tríplice de três blocos tectônicos seguida por uma inversão causada pelo movimento diferencial entre estes blocos (Ebert et al., 1993).

Outra interpretação tectônica para o Cinturão Ribeira é sua formação durante uma colisão obliqua entre duas placas tectônicas com o vetor de transporte principal em direção de E-W (Endo \& Machado, 1993). 


\section{3-OCiclo "Brasiliano"}

O desenvolvimento do Cinturão Ribeira e estruturas a ele associadas encontram se intimamente associado ao Ciclo Brasiliano.

Os maiores indícios da deformação causada pelo Ciclo Brasiliano podem ser encontrados no sudeste brasileiro. Este ciclo tectônico ocorreu durante o Neoproterozóico, tendo reflexos até o início do Paleozóico.

O Ciclo Brasiliano parece ser uma colagem, uma assembléia orogênica de microcontinentes ou placas continentais (placas Amazônica e do Congo de acordo com Endo \& Machado (1993); placas Brasília, Vitória, São Paulo de acordo com Ebert et al. (1993); e Guanhães, Curitiba, Apiaí-Guaxupé e Serra do Mar, de acordo com Campos Neto \& Figueiredo (1995)), arcos de ilha e complexos acrescionários formando o supercontinente Gondwana.

Esta amalgamação implicou em subducção e fechamento de um proto oceano Atlântico (oceano Adamastor) e geração de várias estruturas complexas e cinturões orogênicos.

Diferentes sucessões de eventos tectônicos são propostas para o Ciclo Brasiliano. De acordo com Campos Neto \& Figueiredo (1995) houve primeiramente a subducção de uma placa oceânica com a geração de cinturões de dobramento, acresção de microplacas e formação de um arco magmático do tipo cordilherano com "trending" para nordeste, conhecida como orogenia Brasiliano I, que ocorreu a $600 \mathrm{Ma}$ atrás, seguida por um período extensional caracterizado por plutonismo síncrono com outra orogenia, a orogenia Rio Doce. 
Segundo estes autores a orogenia Rio Doce foi um arco magmático ativo entre 590 a $570 \mathrm{Ma}$, gerado devido a acresção da microplaca Serra do Mar aos domínios orogênicos anteriores.

Plutonismo calcio-alcalino e geração de migmatitos peraluminosos e granitos também são associados a esta orogenia.

Há evidências de depósitos de plataforma que graduam no sentido leste para uma bacia marinha profunda com limite de idade inferior desconhecido. Estes metassedimentos Meso e Neoproterozóicos foram provavelmente a fonte para a formação dos migmatitos peraluminosos (Campos Neto \& Figueiredo, 1995).

Dados geocronológicos obtidos no litoral norte do Estado de São Paulo (Tassinari, 1988) sugerem que o processo de migmatização está relacionado a orogenia Brasiliano I, no início ciclo Brasiliano - Pan Africano. Tassinari (op.cit.) utilizando método de $\mathrm{Rb}$-Sr obteve idades ao redor 600 Ma para estes litotipos.

Heilbron et al.(1996) sugere uma colisão continental gerando encurtamento crustal. Durante esta fase, cavalgamentos dúcteis formaram-se e em uma segunda fase houve convergência obliqua onde as zonas de cisalhamento transcorrentes formaram-se, a fim de acomodar a deformação.

Os efeitos metamórficos do Brasiliano são bem registrados. Eles ocorreram em dois estágios principais: o primeiro associado ao encurtamento crustal e o segundo associado a fase de relaxamento termal que envolveu intensa fusão (Heilbron et al., op.cit.).

É assumido que os cinturões orogênicos formados durante o Ciclo Brasiliano passaram por uma história evolutiva semelhante aos cinturões Pan Africanos, sendo genética e geometricamente correlatos. 


\section{4- O Padrão Estrutural Regional}

\subsubsection{Trabalhos Anteriores}

Diversos trabalhos, cujas áreas de estudo encontram-se vizinhas ou compõem o perfil regional da área de estudo, contribuíram para sintetizar o conhecimento sobre o arranjo estrutural regional. Entre estes trabalhos destacamos os de Ebert \& Hasui (1998), Campos Neto \& Figueiredo (1995) e CPRM (1990).

A partir destes trabalhos unidos aos dados obtidos em campo foi possível elaborar o esboço de um perfil regional que descreve a estruturação regional que a área de estudo encontra-se situada.

Segundo Ebert \& Hasui (1998) o cinturão de cisalhamento transcorrente Paraíba do Sul de orientação NE-SW sofreu uma transpressão dextral enquanto que a porção norte - sul apresenta um sistema de cavalgamento essencialmente frontal. Este quadro teria dado origem a um padrão estrutural complexo gerando domínios de deformação tangencial, com foliação com mergulhos moderados e lineações suaves e indicações cinemáticas de cavalgamentos para NW e um domínio de deformação transcorrente. São comuns estruturas do tipo em flor (regionais), extrusão lateral etc.

Segundo os autores o Cinturão de Cisalhamento Transcorrente Paraíba do Sul, (equivalente ao Cinturão Ribeira do presente trabalho), sobrepõem - se a um sistema de cavalgamentos que teria se formado com a colisão das placas Vitória e São Paulo, esta última já colidida com a placa Brasília em uma fase anterior do ciclo orogênico.

No cinturão, rampas laterais de baixo ângulo e foliação milonítica subvertical exibem lineação de estiramento sub-horizontal que indica movimentação paralela a 
borda da placa. Há também lineações de estiramento obliquas e dip-slip que revelam predominância local de encurtamento e cisalhamento "reverso". A figura 2.2 abaixo ilustra o perfil regional apresentado pelos autores.

Segundo Campos Neto \& Figueiredo (1995), as estruturas regionais apresentam um trend NE, e correspondem a fatias de cisalhamento dúcteis, subhorizontais para o noroeste, seguidas por uma pilha de cavalgamentos também para o noroeste, que são por sua vez superpostos por cinturões de cisalhamento transcorrentes

A foliação principal corresponde a uma $S_{2}$ no terreno supracrustal, enquanto que ocorre como $S_{1}$ nos granitóides e diatexitos. Esta foliação define o plano axial das dobras que podem ser associadas a forte cisalhamento dúctil com transporte para o norte. Esta mesma foliação é deformada por dobras recumbentes assimétricas, cilíndricas geralmente orientadas na direção NE-SW e com vergência para NW.

NW

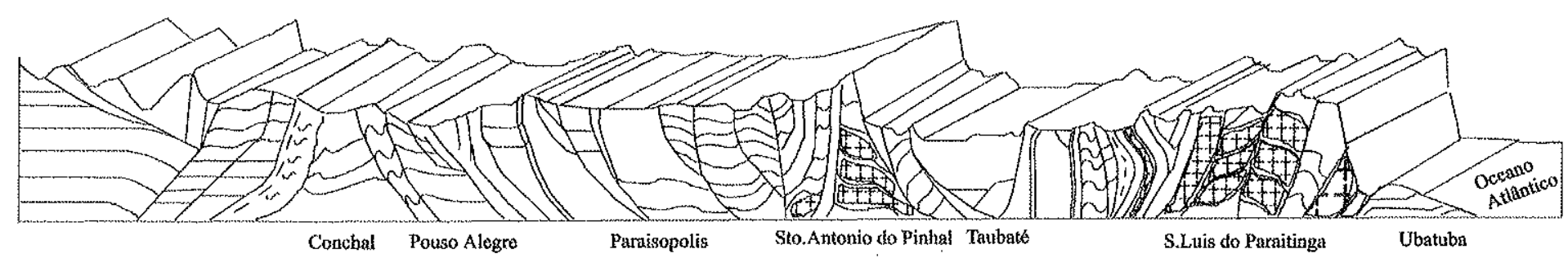

Figura 2.2 - Perfil regional esquemático apresentado por Ebert \& Hasui (1998). São apresentadas as principais estruturas incluindo as zonas de cisalhamento de Pouso Alegre, Taubaté, São Luís do Paraitinga. Este perfil, com orientação NW -...SE, foi feito a norte da área de estudo. 
O sistema de cavalgamento deforma as dobras transformando-as em estruturas cônicas, e rotaciona o eixo B, que indicaria então, a direção de transporte.

Segundo Campos Neto e Figueiredo (1995), as maiores zonas de cisalhamento transcorrentes, parecem ter controlado a colocação dos plútons graníticos. Elas mostram condições iniciais em grau metamórfico elevado, sentido dextral, e com movimento sinistral superimposto e condições de metamorfismo na zona da biotita. É mencionada a ocorrência de antiformes e sinformes em grau baixo de metamorfismo em diferentes escalas. Essas dobras apresentam orientação NNE próxima às zonas de cisalhamento transpressivas e são planas nos domínios entre zonas.

A figura 2.3 traz o perfil regional apresentado pelos autores.

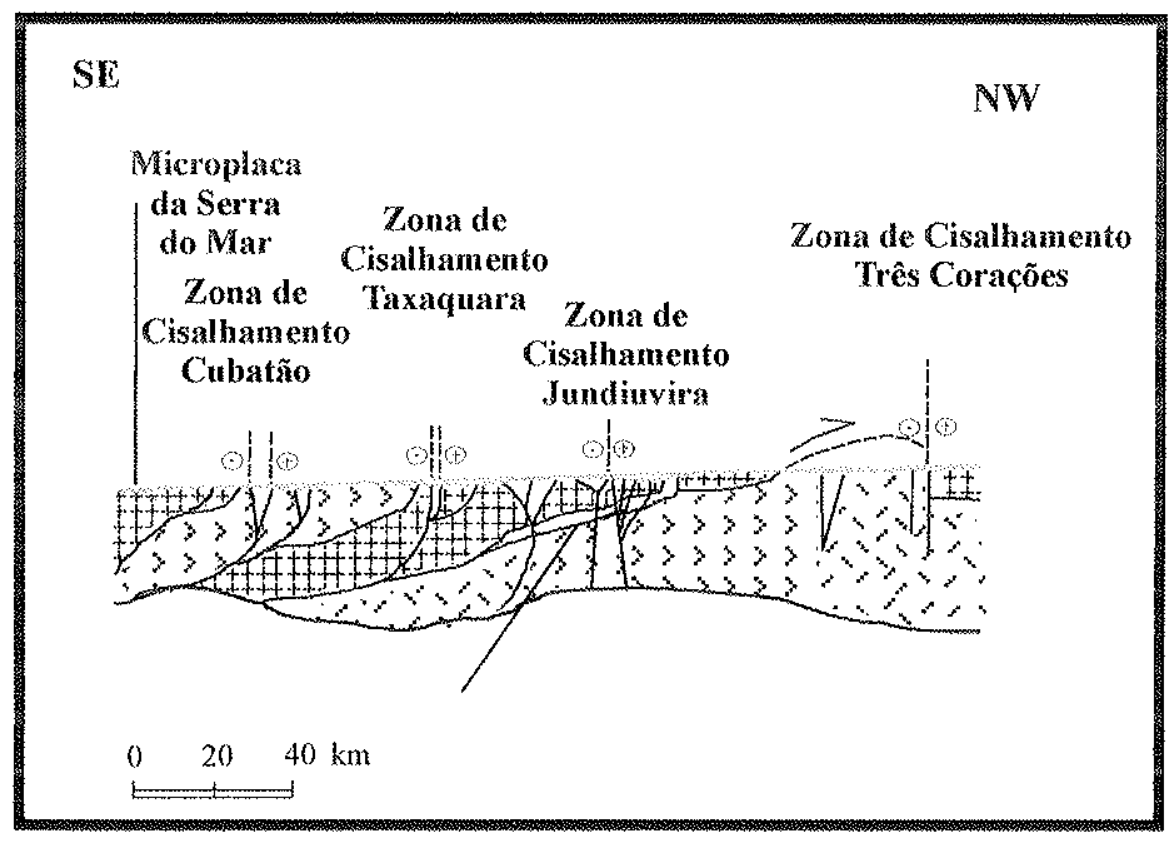

Figura 2.3 - Perfil esquemático apresentado por Campos Neto \& Figueiredo (1995) com cerca de 160 km de extensão e com orientação SE - NW. Apresenta como principais estruturas as zonas de cisalhamento Cubatão, Taxaquara, Jundiuvira e Três Corações. Este perfil foi traçado a norte da área de estudo. 
A CPRM (1990) realizou mapeamento na escala 1:50.000 nas folhas Santa Isabel, Mogi das Cruzes e Mauá, na região do leste paulista. Foram caracterizadas diversas zonas de cisalhamento inseridas na "Zona de Cisalhamento São Paulo", de Hasui \& Sadowski (1976).

Segundo os autores o registro metamórfico deformacional na área apresenta uma deformação inicial (Dn) gerando até duas foliações, metamorfismo na fácies anfibolito e tendo como estruturas um sistema de cavalgamentos de baixo a médio ângulo de mergulho, gerando um bandamento composicional, dobras isoclinais e recumbentes, além de intenso estiramento, boudinage e lenticularizacão. Além desta deformação são também observadas uma deformação milonítica $(\mathbf{D m})$ gerando foliação milonítica e metamorfismo na transição das fácies xisto-verde / anfibolito; esta fase corresponde a implantação de um sistema de transcorrência de alto ângulo com desenvolvimento das zonas de cisalhamento transcorrentes gerando intensa lenticularização, estiramento, boudinage, e rotação dos litotipos. Uma deformação tardia $(\mathrm{Dn}+1)$ é caracterizada como responsável pela geração de dobramentos cilindricos, suaves a abertos com desenvolvimento de clivagem de crenulação e localmente uma foliação $\mathrm{Sn}+1$.

\subsubsection{Perfil Regional Esquemático}

Os trabalhos de campo realizados permitiram um detalhamento da estrutura local, na área que vai desde a Zona de Cisalhamento Bairro do Alto (a oeste), no Bairro São Lourenço, até a ocorrências dos cavalgamentos (a leste) na cidade de São Sebastião.

A figura 2.4 apresenta estes perfis. 


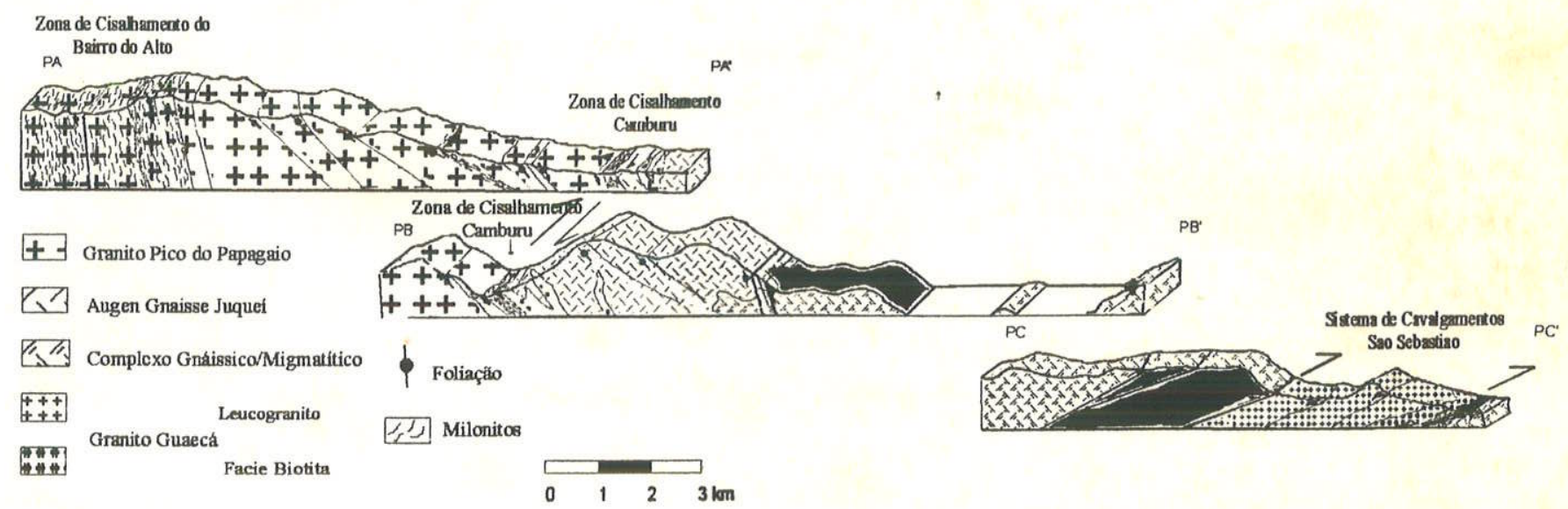

Figura 2.4 - Perfis destalhados na área de estudo. De PA a PA' temos o perfil da Zona de Cisalhamento Bairro do Alto até a Zona de Cisalhamento Camburu, de PB a PB' temos o perfil da Zona de Cisalhamento Camburu ao início do domínio dos cavalgamentos e no perfil PC a PC' temos a ocorrência dos cavalgamentos. Todos os perfis tem orientação NW - SE.

Todos os perfis apresentados neste capítulo serviram como base para a elaboração de um perfil esquemático regional (figura 2.5). Desta forma, podemos situar a estruturação da área em estudo dentro de um contexto regional.

Percebe-se que a disposição da estrutura regional que compõe o Cinturão Ribeira sugere a ocorrência de várias estruturas em flor, bem como diversas zonas transcorrentes e cavalgamentos associados. Este arranjo, do qual a área de estudo está incluída, sugere tratar-se de uma geometria gerada por um sistema transpressivo. 


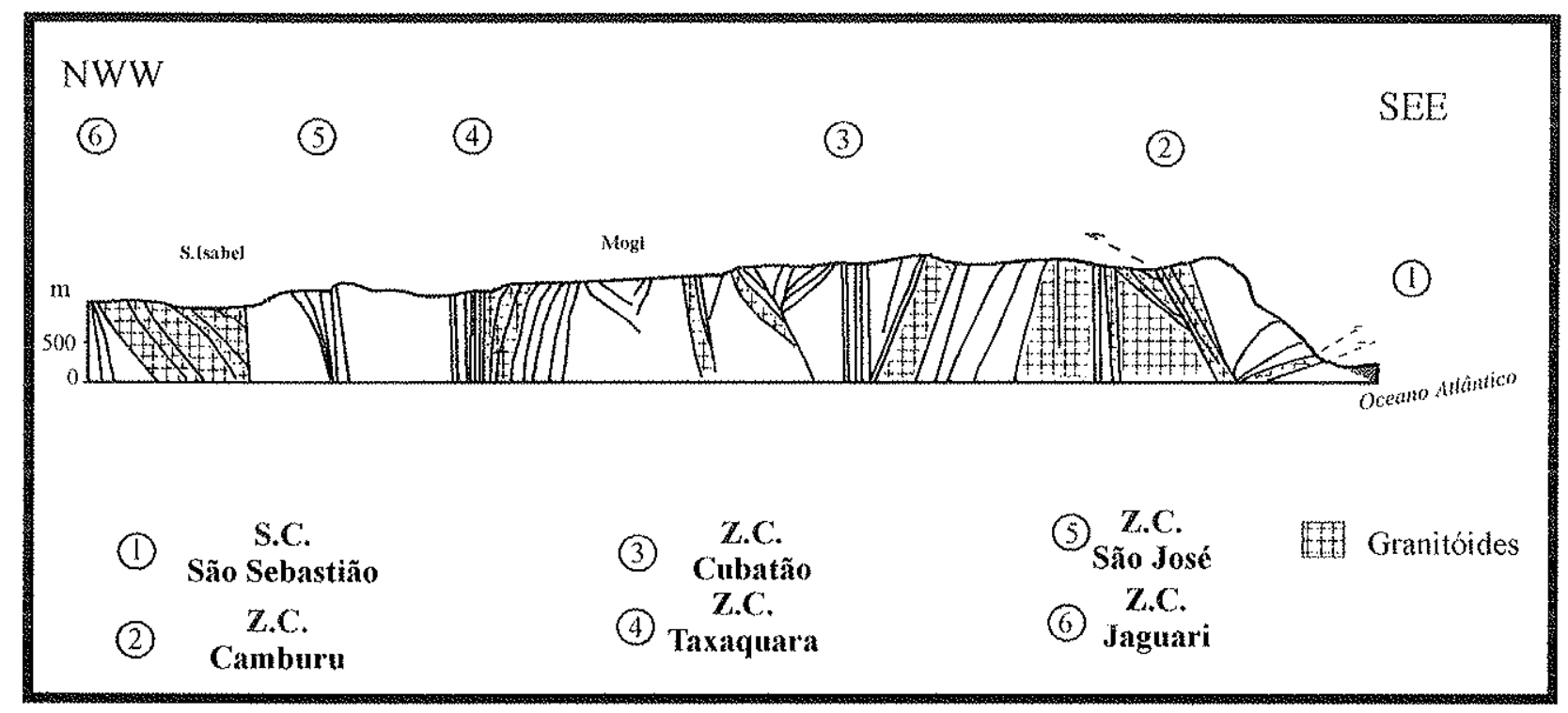

Figura 2.5 -..-Perfil geológico regional esquemático, baseado nos trabalhos anteriores, em dados de campo e interpretação da imagem de radar. 
Capítulo 3 


\section{Capítulo 3: Interpretacão da Imagem do Satélite de Radar Europeu (ERS-1)}

\section{1-Introducão}

A área de estudo tem relevo elevado que varia, em altitude, do nível de mar até cerca de $1200 \mathrm{~m}$ e apresenta densa vegetação. A acessibilidade e afloramentos rochosos na costa são boas mas são pobres no interior onde a vegetação é mais densa e os acessos limitados. Estes fatos combinados com a extensão da área em estudo $\left(800 \mathrm{~km}^{2}\right)$ são fatores limitantes à cartografia de campo.

O âmbito principal deste capítulo é caracterizar o padrão estrutural da área através do tratamento e interpretação de uma imagem de radar adquirida pelo Satélite de Radar Europeu (ERS).

Radar é um sensor remoto que trabalha na região de microondas do espectro eletromagnético, na faixa que varia de 8 a $14 \mathrm{~mm}$. É considerado um método ativo porque produz e emite radiação artificial que é registrada através de um detector. A resolução da imagem de radar é controlada pela duração de pulsação e pela largura da varredura. Há várias vantagens em se utilizar imagens de radar: primeiro, é um sistema que funciona independente de ser dia ou noite; segundo, pode ser utilizado em qualquer condição climática e terceiro, pode ser dirigido à atmosfera ou para a superficie da Terra, dependendo do comprimento de onda utilizado. Ondas de radar são geradas em um único comprimento de onda, e em fase. Isto torna possível o uso de radar de abertura sintético (Syntetic Aperture Radar - SAR) com resolução boa e independência de alcance (Lillesand \& Kiefer, 1994).

Como mencionado nos capítulos anteriores, duas zonas de cisalhamento, Bairro do Alto e Camburu e um sistema de cavalgamentos, Sistema de Cavalgamentos São Sebastião, ocorrem na área de estudo. É esperado que eles tenham uma expressão topográfica forte. 
Vários estudos mostram que imagens de radar têm vantagens especiais para geologia estrutural, devido ao fato que acentuam a topografia de superfície e aumentam o contraste associado com características de escalas menores porque características topográficas com limites angulares agem como refletores naturais. Esta dependência do radar da aspereza de superfície torna possível a identificação de variações de micro relevo invisíveis em outros sensor ópticos (Drury, 1993).

Uma imagem de radar ERS-1 foi escolhida para ajudar na interpretação e caracterização estrutural regional.

Interpretação e análise de imagem de radar envolvem três processos principais: correção radiométrica e geométrica, realce e classificação.

Correções radiométricas e geométricas são procedimentos de restauração, normalmente aplicados antes da manipulação e a análise da imagem. São necessários para corrigir as distorção radiométricas porque afetam o contraste de nivel de cinza e reduzem a interpretabilidade da imagem. Correção geométrica é aplicada para compensar as distorções introduzidas pela variação da altitude, atitude, curvatura de terra etc. para obter na imagem a integridade de um mapa. Realce implica em processos de contraste de nivel de cinza; geralmente usa-se o realce linear de contraste (stretching) e a filtragem. Seu propósito é aumentar interpretabilidade da imagem (Lillesand \& Kiefer, 1994).

Como na imagem de radar o controle dominante sobre os valores de DN (digital number) é feito pela topografia, em geral a precisão de classificação tende a se corromper (Drury, 1993).

A interpretação de imagem foi realizada tanto durante a fase de trabalhos de campo como posteriormente. 


\section{2 - Imagem do Radar Curopeu - ERS-1}

O satélite ERS é um SAR (Syntetic Abertura Radar), um sistema desenvolvido pela Agência Espacial Européia (ESA) desde 1991 para prover dados durante um período de 2 a 3 anos.

O ERS-1 tem uma órbita sol-síncrona com inclinação de $98.5^{\circ}$, um período de "retorno" de 16 a 18 dias, três sensores e opera na faixa de comprimento de onda curto (banda C). Emprega polarização VV e um ângulo de incidência relativamente íngreme $\left(23^{\circ}\right)$, mais alto que outros sistemas (Lillesand \& Kiefer, op.cit.).

A resposta na imagem SAR é principalmente controlada pelas propriedades físicas da superfície como: atitude do relevo, aspereza e constante dielétrica (Elachi et al., apud Schetselaar \& McDonough, 1996). Outro fator importante que influencia a resposta é o ângulo de depressão da antena.

Variação no ângulo de depressão (e em contrapartida no ângulo de visada, "look angle" ) acentua a topografia de superfície de formas diferentes, causando graus diferentes de layover, foreshortening e sombreamento (shadowing) (Drury, 1993). Normalmente a incidência em vertentes com mergulho na direção da incidência resulta em alto retorno que significa tons de imagem luminosos. Vertentes com mergulhos opostos ao sensor têm baixo ou nenhum retorno (Lillesand \& Kiefer, 1994).

A imagem SAR - ERS-1 tem um ângulo de visada relativamente alto $\left(23^{\circ}\right)$ que maximiza o efeito de escala (layover) (Drury, op.cit.). É um ponto positivo em terrenos planos mas em terrenos acidentados acentua este efeito e técnicas especiais devem ser aplicadas para que ele seja reduzido.

A imagem ERS-1 utilizada tem modo descendente, cobrindo uma área de aproximadamente $160 \times 160 \mathrm{~km}$. A resolução de tamanho do pixel é de $12.5 \times$ 
12.5m. Uma quarta parte da imagem corresponde à área de estudo (figura 3.1). Nesta parte foram feitas as correções radiométricas, geométricas e realce para melhorar sua interpretabilidade.

\section{3 - Distorcões Radiométricas e Geométricas em SAR}

Distorções radiométricas são causadas pela atmosfera pela qual o sinal emitido e registrado pelo sensor do satélite tem que passar (Lillesand \& Kiefer, op.cit). O próprio sensor também é uma fonte de distorção.

Os aspectos que influenciam o conteúdo radiométrico da imagem SAR são principalmente: mancha (speckle) e padrão de antena.

A geometria da antena pode causar distorção nas intensidades dos pixels que estiverem na direção de alcance. Aparece como aumento e diminuição gradual nos níveis de cinza da coluna principal. No caso de ERS-1 as imagens foram calibradas e corrigidas para a antena padrão de SAR, consequentemente nenhuma correção adicional foi necessária.

Imagens de radar são mais salpicadas em sua aparência quando comparadas as imagens ópticas.

Isto porque um número grande de sinal de retorno (backscatter) de objetos individuais, representam uma cela de resolução (pixel) causando variação no nível de cinza do pixel adjacente na imagem, o chamado efeito mancha (speckle effect), (Lillesand \& Kiefer, 1994).

Manchas causam aparência granosa e como trata-se de um efeito aleatório não é possível removê-1o completamente. Mas existem algumas técnicas para redução de manchas, a maioria delas implicando em uma redução da resolução espacial. 


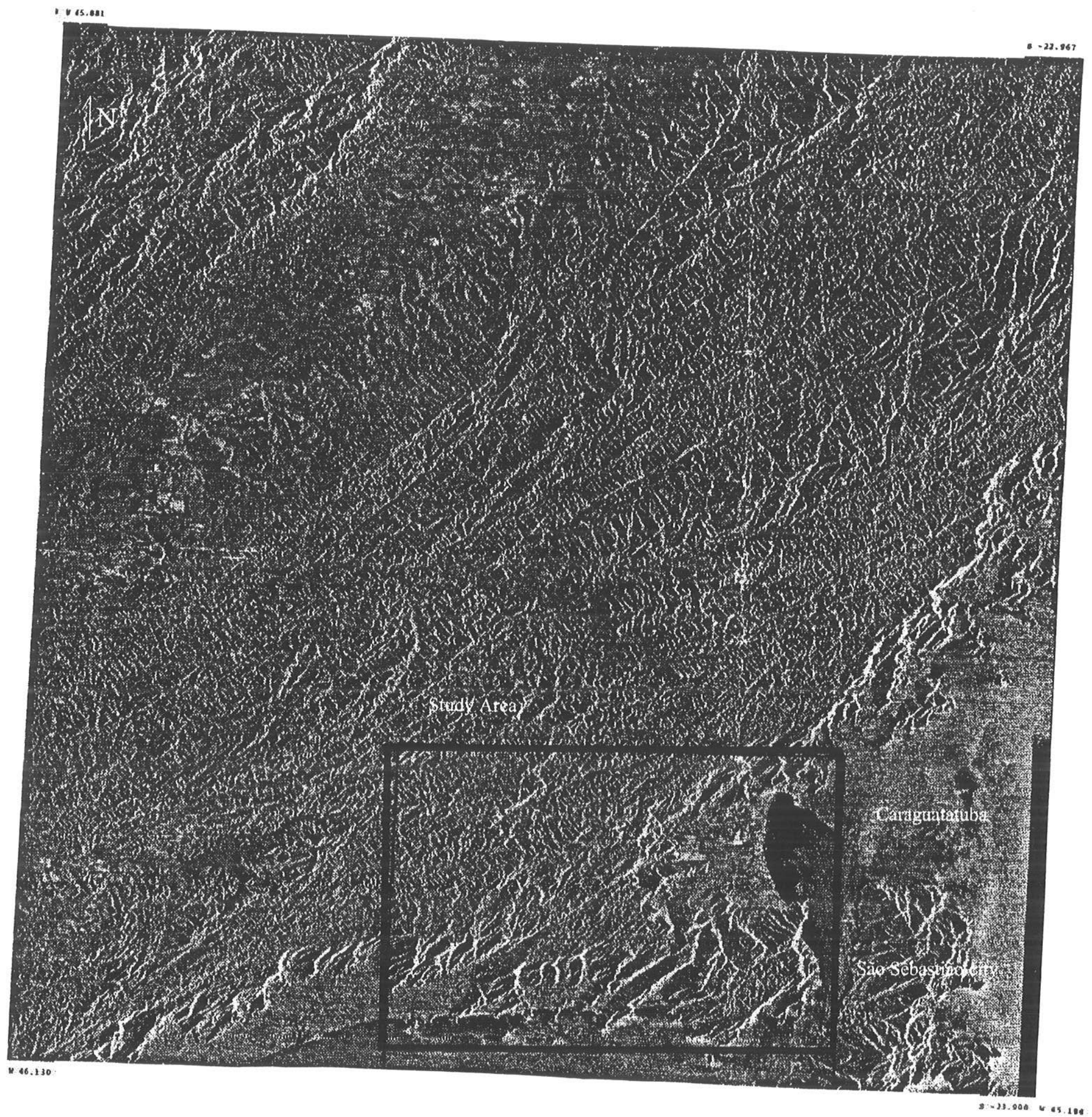

Figura 3.1 - Imagem ERS da área de estudo. Ref da cena. número: órbita 25405 frame 407.

Note a orientação superior da imagem é possível ver o vale de Paraíba.

Ribeira.

A imagcm ERS-1 foi adquirida em 24 - maio - 96, em modo descendente ` tem uma visada oriental. 
As fontes de distorção geométrica em imagens de SAR são altitude, velocidade da plataforma do sensor, distorções panorâmicas, etc.

Como mencionado anteriormente, relevo acidentado pode causar efeitos geométricos estranhos. Em áreas montanhosas o topo é registrado mais próximo a plataforma do que a base o que cria a impressão que a montanha "deita" na direção da plataforma, este efeito é chamado escala (layover). Outro efeito geométrico que afeta imagens é o foreshortening. Ele ocorre quando a superfície da vertente é menos íngreme que a onda emitida pelo radar (wavefront) que atinge a montanha. Neste caso a vertente aparece menor na imagem do que é na realidade (Lillesand \& Kiefer, op.cit).

\section{4- Correcão Radiométrica}

Antes das correções geométricas devem ser feitas as correções radiométricas.

Correções radiométricas envolvem manchas (speckle) e padrão de antena. A redução de manchas pode ser feita através de filtragem. Pohl (1996) utilizou dados de ERS-1 para atualização de mapas topográficos e concluiu que o Filtro Mapa Gama (Gama Map Filter) produz resultados superiores (usando uma janela $3 \times 3$ ) para este fïm. O filtro Gama é usado para remover ruído de freqüência (manchas) enquanto preserva feições de freqüência alta como as extremidades. A descrição completa do algoritmo é dando por Lopes et al. (1993).

O filtro Frost aprimorado (Enhanced Frost filter) também é baseado no mesmo princípio. Ele suaviza a imagem e preserva as extremidades. O princípio do filtro é computar um grupo de valores de peso aplicados para cada pixel dentro da janela de filtro que cerca cada pixel. Schetselaar \& McDonough (1996) aplicaram um filtro Frost $7 \times 7$ para redução de manchas para mapear uma zona de cisalhamento no Canadá. 
Outro fator que afeta fortemente a qualidade da imagem processada é o tamanho do filtro.

Janelas de filtro muito pequenas não são efetivas na redução de manchas, porém com o uso de janelas grandes, detalhes podem ser perdidos.

Neste estudo, os filtros Gama e Frost aprimorado foram aplicados utilizandomse janelas com tamanhos diferentes. Comparando as imagens resultantes concluímos que o filtro Gama é mais indicado para a interpretação visual porque as manchas são mais eficazmente reduzidas em comparação com os outros filtros. O contraste é reduzido, mas isto não afeta interpretabilidade da imagem. Por outro lado, para geologia estrutural às vezes a redução de manchas não afeta a interpretação significativamente, consequentemente uma redução mínima pode ser aplicada sem diferença significante na interpretação, já que por vezes a presença de manchas até ajuda. De acordo com este ponto de vista o Filtro Frost aprimorado em uma janela $3 \times 3$ seria o melhor resultado obtido.

A figure 3.2 traz: a imagem ERS-1 original (figura $3.2 \mathrm{~A}$ ), o filtro Frost aprimorado utilizando-se uma janela de tamanho $3 \times 3$ (figura $3.2 \mathrm{~B}$ ), o mesmo filtro porém aplicando-se uma janela de tamanho $7 \times 7$ (figura 3.2 C) e o filtro Gama aplicando-se uma janela de tamanho $7 \times 7$ (figura 3.2 D).

\section{5- Correcão Geométrica}

A intenção da correção geométrica é corrigir distorções para que se possa utilizar a imagem como um mapa.

Para este estudo a correção geométrica foi feita utilizando-se um módulo disponível no software PCl. A correção é baseada na imagem simulada, SARSIM1 (figura 3.3) que é criada a partir do DEM, modelo digital de elevação do terreno 
(figura 3.4) e de informações provenientes da imagem de radar como o ângulo de olhar (look angle), altitude da plataforma do satélite, heading angle. Esta imagem simulada georeferenciada, SARSIM1, parece semelhante à imagem SAR original. Ela é utilizada como uma imagem "mestra" para coletar os pontos de controle usados para georeferenciar a imagem ERS-1 original. Como a imagem simulada contém o efeito de escala (layover), os pontos de controle utilizados serão mais precisos do que se um mapa topográfico fosse usado.

Os pontos de controle são armazenados em um segmento da própria imagem ERS-1, e o processo de reamostragem (resample) é executado.

Este procedimento de correção da geometria do Radar é mais vantajoso que uma correção geométrica normal (feita utilizando-se o mapa topográfico) porque elimina distorções que são típicas à imagem de radar como o layover e o foreshortening, particularmente fortes na área de estudo devido ao relevo acidentado.

Infelizmente o procedimento não teve sucesso porque o parâmetro de órbita exigido para a correção do deslocamento do relevo, cerca de $2 \mathrm{~km}$, não pôde ser extraído da cena original do radar.

Um procedimento de correção geométrico normal, usando o mapa topográfico para coletar os pontos de controle, foi utilizado porém não foi tão efetivo devido ao efeitos fortes de layover.

\section{6-Realce da Imagem}

Normalmente o uso de filtros passa-alta (high pass) e textural criam artefatos a menos que as manchas sejam reduzidas. Por este motivo a correção radiométrica deve ser executada como primeiro processo. 
Capítulo 3 - Interpretação da Imagem... Cristina de Queiroz Telles Maffra - dissertação de mestrado - 2000

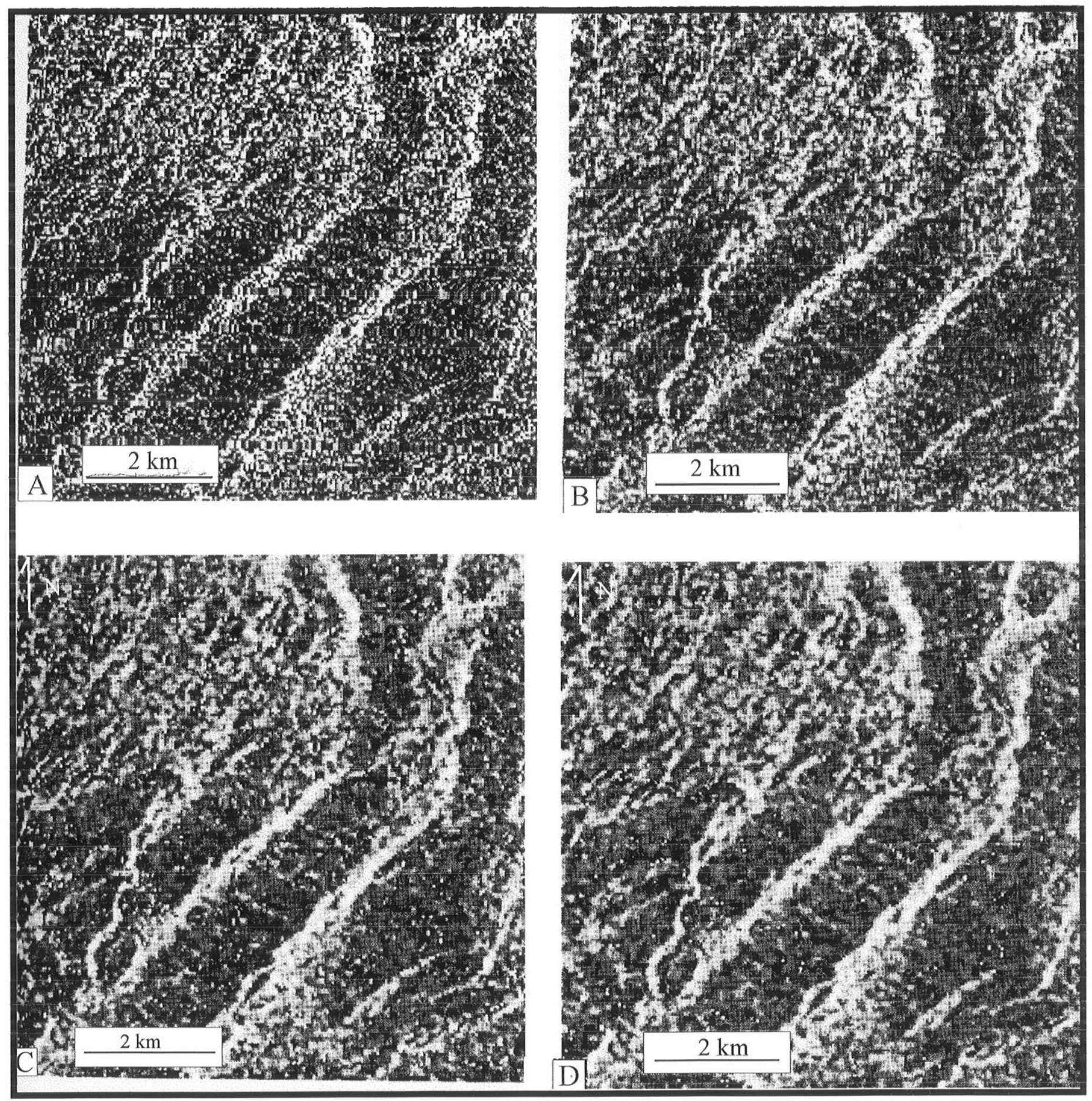

Figura 3.2 -

A: Imagem SAR original;

B: Filtro Frost aprimorado em tamanho $3 \times 3$;

C: Filtro Frost aprimorado em tamanho 7x7;

D: Filtro Gama em tamanho $7 \times 7$.

Note a diferença na redução das manchas quando o filtro com janela $3 \times 3$ é utilizado (direita superior) e quando a janela $7 \times 7$ é utilizada (duas imagens na parte inferior). 
O programa RSTR ( Radar Data Stretch), disponível no pacote do software PCI, permite a realização de realce não linear de contraste ( non linear stretching ) na imagem a fim de aumentar sua interpretabilidade através do aumento da variabilidade nos níveis de cinza.

Os dados da imagem a ser estirados têm que ter uma distribuição Gaussiana, o que significa que mais de $95 \%$ da imagem tem que estar contida dentro dos dois desvios padrões do valor principal. $\mathrm{O}$ algoritmo executa o seguintes passos:

a) O desvio padrão e o desvio médio são calculados;

b) Dois valores de níveis de cinzas são calculados correspondendo a dois desvios padrões, abaixo e acima do valor principal (Z1 e Z2).

c) $\mathrm{O}$ intervalo de 0 a $\mathrm{Z} 1$ corresponde a base $2.5 \%$ da escala de cinza. $\mathrm{O}$ intervalo de Z1 a Z2 correspondem a 95\% da escala de cinza e o de Z2 a 255 (saturação) é o topo $2.5 \%$ da escala de cinza.

d) A extensão de contraste é executada com Z1 atribuído valor 0 e Z2 atribuído o valor 255 .

O resultado é uma imagem com contraste de cinza melhorado (figura 3.5) que será utilizada para a interpretação.

\section{$\underline{3.7 \text { - Interpretacão da Imagem }}$}

A área de estudo tem um controle topográfico estrutural forte. Lineamentos com orientação NE-SW, que correspondem a escarpas e vales alinhados, são as características mais proeminentes na imagem (figura 3.5). 


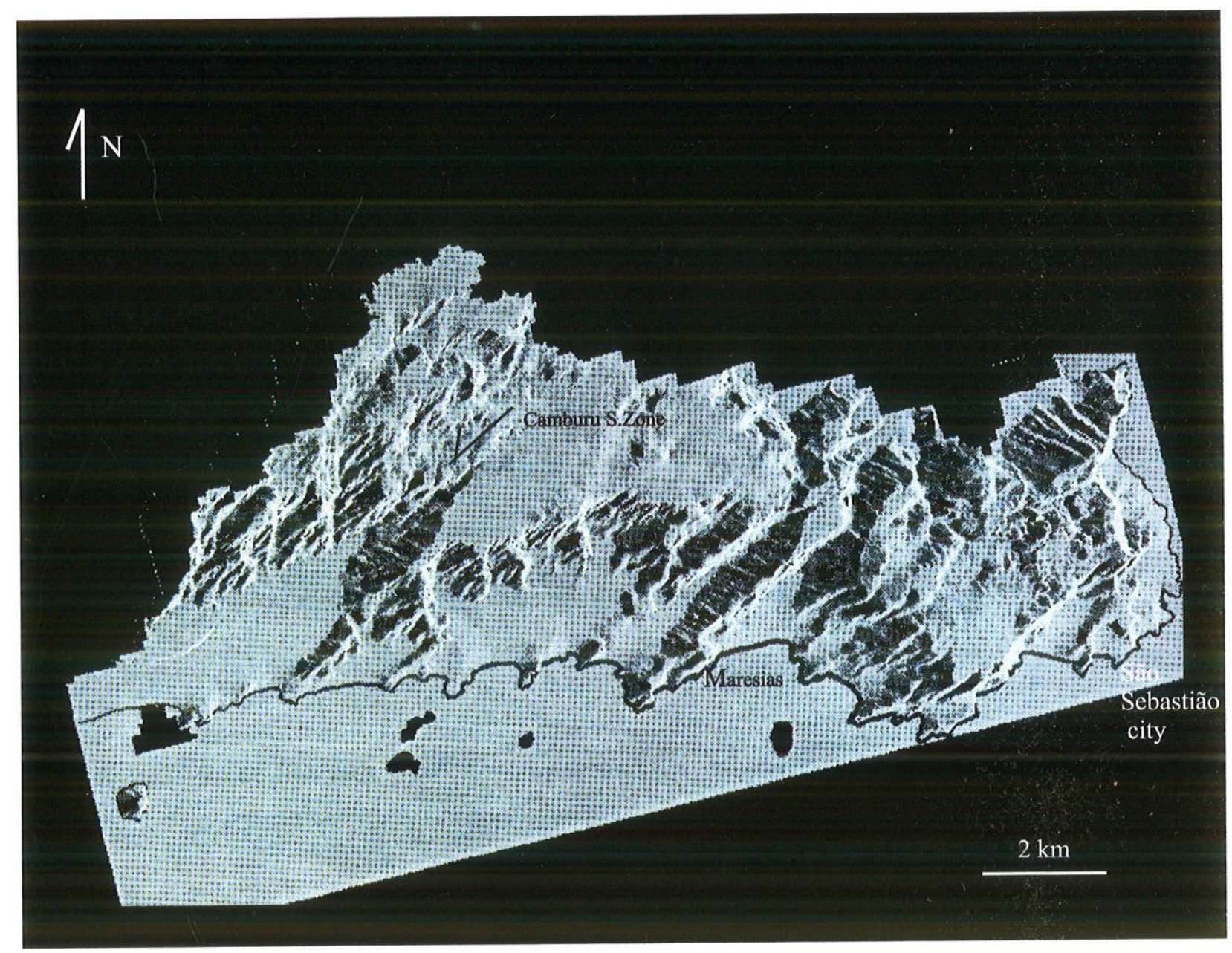

Figura 3.3 - Imagem simulada SARSIM1 criada a partir do DEM.

Note como o efeito de escala (layover) é reproduzido nesta imagem.

Permite uma localização precisa dos pontos de controle para que seja feita a correção geométrica. 


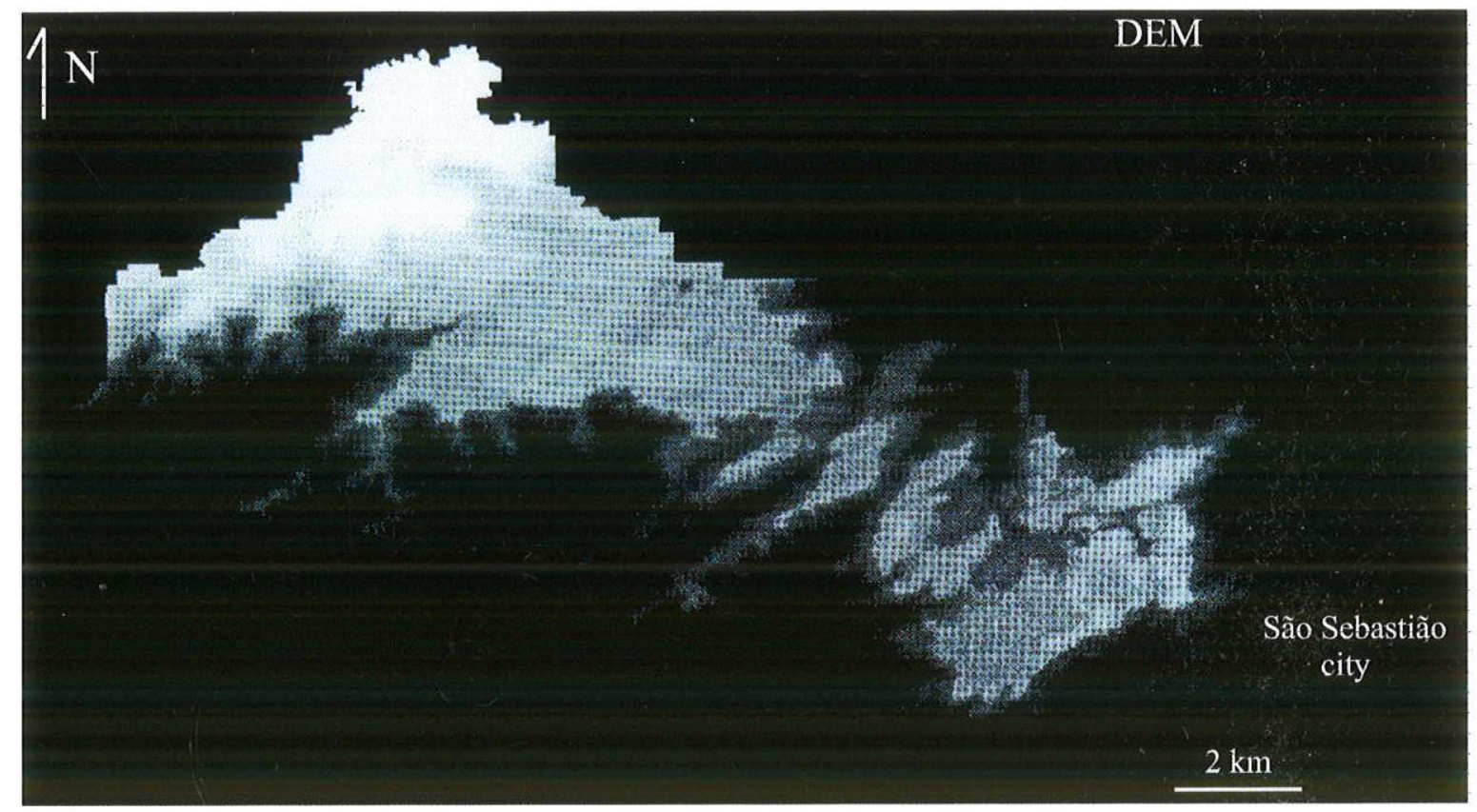

Figura 3.4 - Modelo Digital de Elevação do Terreno (DEM) para a área de estudo. Este modelo foi desenvolvido a partir de um mapa com as curvas de nível digitalizadas e posteriormente utilizado um software específico (Ilwis). A partir deste modelo foi criada a imagem de radar simulada SARSIM1.

Como a imagem ERS-1 foi adquirida em modo descendente, com visada para leste, esta favorece estruturas com orientação NE- SW, que correspondem a 
orientação da foliação regional e das principais zonas de cisalhamento na área. As vertentes que mergulham para oeste tendem a apresentar uma valor elevado de backscatter e aparecem na imagem como tom branco brilhante, enquanto que as vertentes com mergulho para leste encontram-se quase completamente na sombra, aparecendo na imagem como tons escuros, como mostrado na figura 3.5 .

O lineamento mais proeminente corresponde à Zona de Cisalhamento Camburu (segmento A da figura 3.5 e figura 3.6). Trata-se de um lineamento bem definido com orientação $\mathrm{NE}$, formando um baixo topográfico (vale) no planalto entre o granito Pico do Papagaio e o Augen Gnaisse Juqueí. Na planície costeira de Boracéia, cumes lineares com orientação SW, parecem coincidir com o fabric milonítico forte da Zona de Cisalhamento Camburu. Este efeito descreve um padrão interessante que mostra topografia negativa no vale e topografia positiva na planície do litoral. Outra característica interessante é deflexão dos lineamentos ao redor da zona de cisalhamento; eles descrevem um padrão que indica movimento dextral, coincidindo com o sentido do movimento mostrado por indicadores cinemáticos em pequena escala. Deflexão em radar deve ser considerada cuidadosamente. Com freqüência não correspondem a feiçôes estruturais. No caso da área de estudo optou-se por interpretar esta deflexão como indicador devido à existência de outras evidências de campo que apoiam este resultado.

Fortes lineamentos ocorrem ao longo do vale de Boiçucanga (segmento D, figura 3.5), do vale de Maresias (segmento E, figura 3.5) e a escarpa elevada de praia de Guaecá. A verificação em campo apontou ativação rúptil em Boiçucanga com ocorrência de vários planos de falhas e slickensides. No vale de Maresias nenhuma evidência de cisalhamento rúptil ou dúctil foi encontrada, apenas um aumento no ângulo de mergulho da foliação (veja figura 5.1). 
Na base da escarpa em Guaecá ocorre o principal cavalgamento do Sistema de Cavalgamentos de São Sebastião (SCSS). O SSTS é caracterizado pelo relevo marcante e uma vertente ampla com mergulho suave.

Todos estes lineamentos mencionados poderiam ser relacionados a reativação tectônica que ocorreu durante o Cretáceo Inferior, Eoceno e Mioceno, responsável pela morfologia do relevo atual (Campanha, Ens \& Ponçano, 1994).

-... Não foram identificadas variações litológicas na imagem ERS-1. Este fato pode ser explicado pelos litotipos envolvidos. Como as litologias principais correspondem a granitos, gnaisses e migmatitos, nenhuma variabilidade textural alta ocorre. A diferença textural maior ocorre entre os sedimentos não consolidados, depositados nas planícies litorâneas, e o embasamento cristalino.

Uma característica observada é o padrão erosivo diferente observado na parte oeste da imagem, (canto superior esquerdo separado pela linha pontilhada, figura 3.5 e 3.6). Esta é a área onde o Granito Pico do Papagaio ocorre. O Granito, em comparação com o Complexo Gnáissico / Migmatítico (que ocupa a parte central e oriental da imagem) mostra - se mais homogêneo e com padrão erosivo isotrópico.

Ainda na porção oeste da imagem ocorre a Zona de Cisalhamento Bairro do Alto. Esta zona difere da Zona de Cisalhamento Camburu porque não mostra um único lineamento retilíneo, mas vários lineamentos pequenos que ocorrem ao longo de uma zona larga. A Zona de Cisalhamento Bairro do Alto não é tão evidente na imagem de radar; tem orientação NE suave, provavelmente isto pode ser reflexo de ser uma zona que não controla a topografia.

A imagem sugere que a Zona de Cisalhamento Bairro do Alto afeta lineamentos prévios com orientação N--S (parte oeste da imagem, porção superior esquerda da figura 6.5 e 6.6) porém este fato não foi confirmado no campo. 
Uma cópia em papel da imagem foi utilizada durante o trabalho de campo e sua interpretação estrutural foi feita.

Durante o trabalho de campo percebeu-se que alguns lineamentos interpretados não correspondem a feições estruturais. Isto pode ocorrer devido ao fato que a imagem SAR tem incidência a partir do leste, o que "prioriza" alguma orientações. Por outro lado, algumas outras expressões estruturais não são evidentes na imagem.

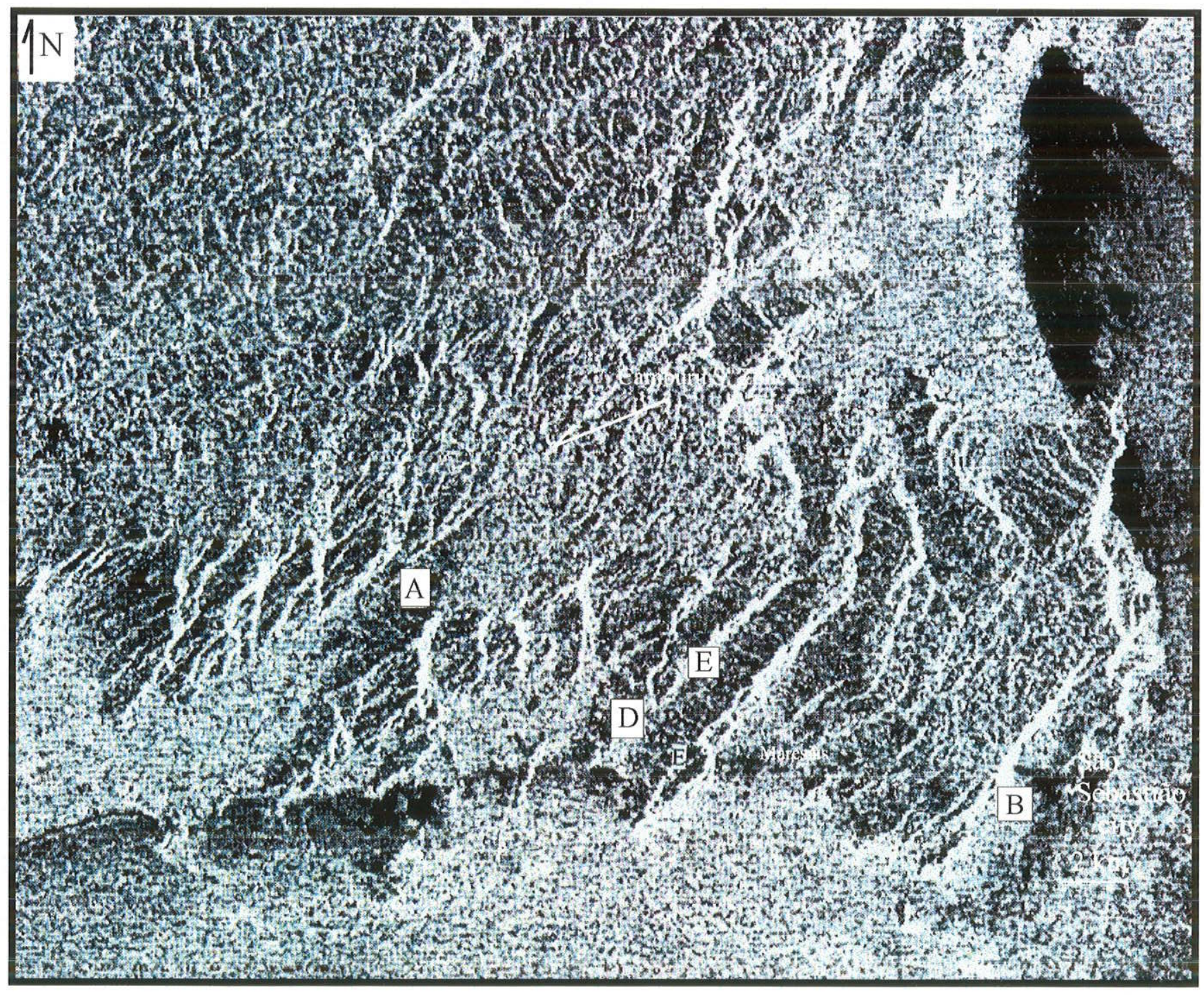

Figura 3.5 - Imagem ERS-1 com os lineamentos principais após os tratamentos radiométrico, geométrico e filtragem

A corresponde à Zona de Cisalhamento Camburu (ZCC).

B corresponde ao cavalgamento principal do Sistema de Cavalgamentos São Sebastião (SCSS).

D e E são respectivamente o vales de Boiçucanga e de Maresias. 


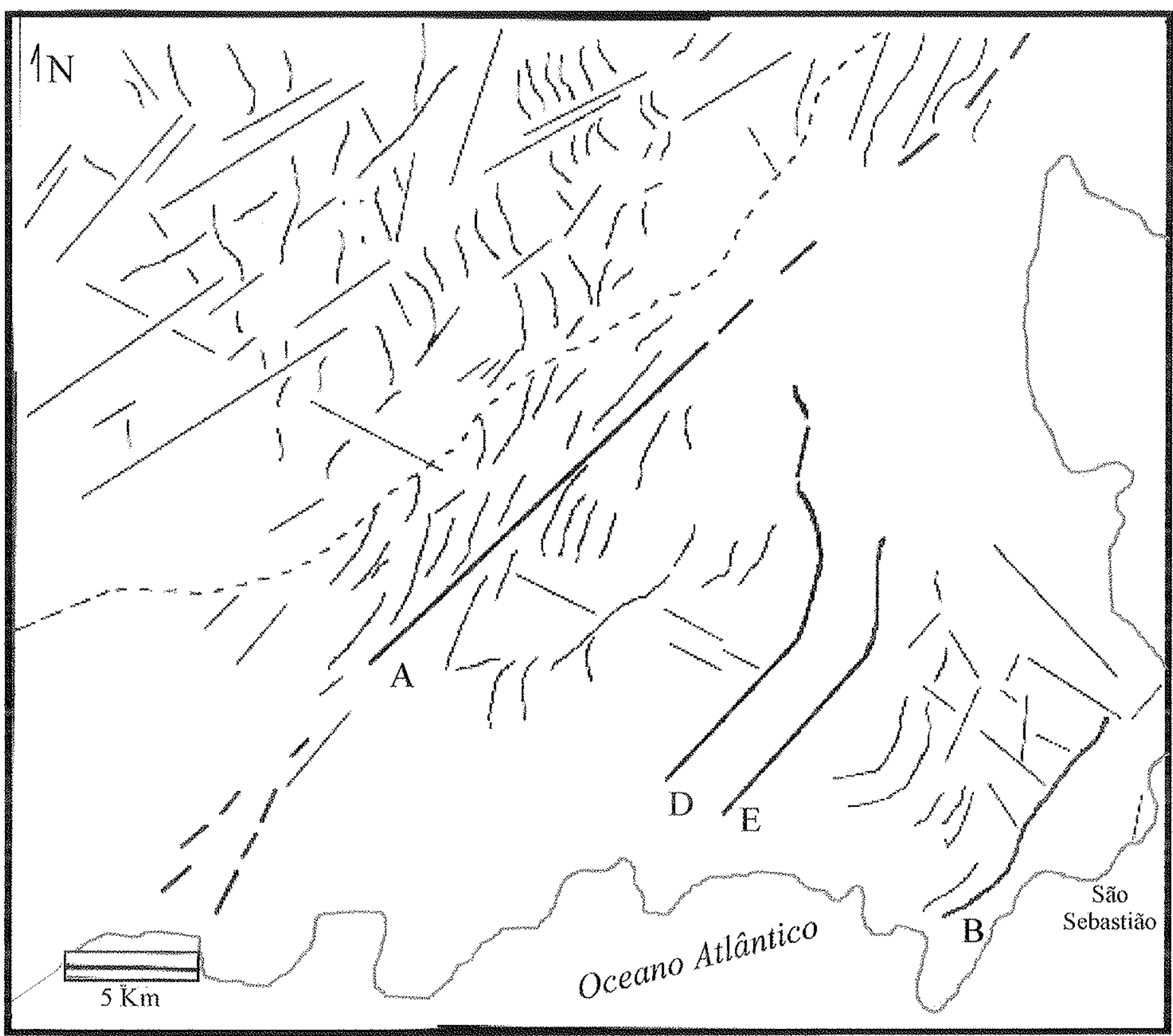

Figura 3.6 - Interpretação da Imagem ERS-1.

A corresponde à Zona de Cisalhamento Camburu ( $\mathrm{ZCC}$ ).

B corresponde ao cavalgamento principal do Sistema de Cavalgamentos São Sebastião (SCSS).

D e $\mathbf{E}$ são respectivamente o vales de Boiçucanga e de Maresias.

A linha pontilhada separa áreas com padrão erosivo distinto. 
Capítulo 4 


\section{Capítulo 4: Descricão das Unidades Litológicas}

\section{1- Introducão}

A área em estudo apresenta litologias pertencentes ao Complexo Costeiro bem como corpos graníticos de idade neo proterozóica, e diques básico a alcalinos de idade meso - cenozóica.

O Complexo Costeiro faz parte do Cinturão Ribeira, cuja expressão estrutural é representada na área em estudo pela Zona de Cisalhamento Transcorrente do Bairro do Alto (ZCBA) e pela Zona de Cisalhamento Transcorrente Camburu (ZCC).

A figura 3.1 ilustra as principais unidades litológicas e estruturas encontradas na área de estudo.

Dois corpos graníticos ocorrem na área: Pico do Papagaio e o de Guaecá. $O$ Granito Pico do Papagaio aflora entre as Zonas de Cisalhamento do Bairro do Alto (a oeste) e o a Zona de Cisalhamento Camburu (a leste). Trata-se de um monzogranito com foliação com intensidade variável, de fraca a intensa. Interpretado como de idade cambriana inferior e como um granito peraluminoso sin a tardi colisional (Campos Neto \& Figueiredo, 1995).

Logo uma unidade de Augen-Gnaisses é exposta a leste da Zona de Cisalhamento Camburu. Seguindo mais para Leste, esta unidade mostra um contato transicional com Complexo Gnaissico/Migmatítico, a maior e mais heterogênea unidade litológica na área de estudo.

O Granito Guaecá é um granada-leucogranodiorito. Ocorre bem próximo à cidade de São Sebastião, e está em contato tectônico com o Complexo Gnaissico / Migmatítico. Sua assembléia mineral consiste em granada, biotita, muscovita, sillimanita, e cordierita, que aponta para condições de metamorfismo em fácies 
anfibolito alto, sobreposta por metamorfismo de grau mais baixo em fácies xisto verde.

Enxames de dique básico a alcalinos ocorrem na parte oriental da área. Eles são atribuídos a um magmatismo Juro-Cretácico relacionado a abertura do Oceano Atlântico (Garda \& Schorscher, 1994).

Sedimentos de idade cenozóica ocupam a porção leste da área em estudo. São depósitos clásticos heterogêneos, marinhos e continentais.

As descrições litológicas providas neste capítulo estão baseadas na cartografia em escala 1:50.000 realizada pelo Instituto Geológico de Estado de São Paulo em 1995 e 1996 nos quais a autora participou, e em cartografia adicional realizada em 1997 para esta dissertação.

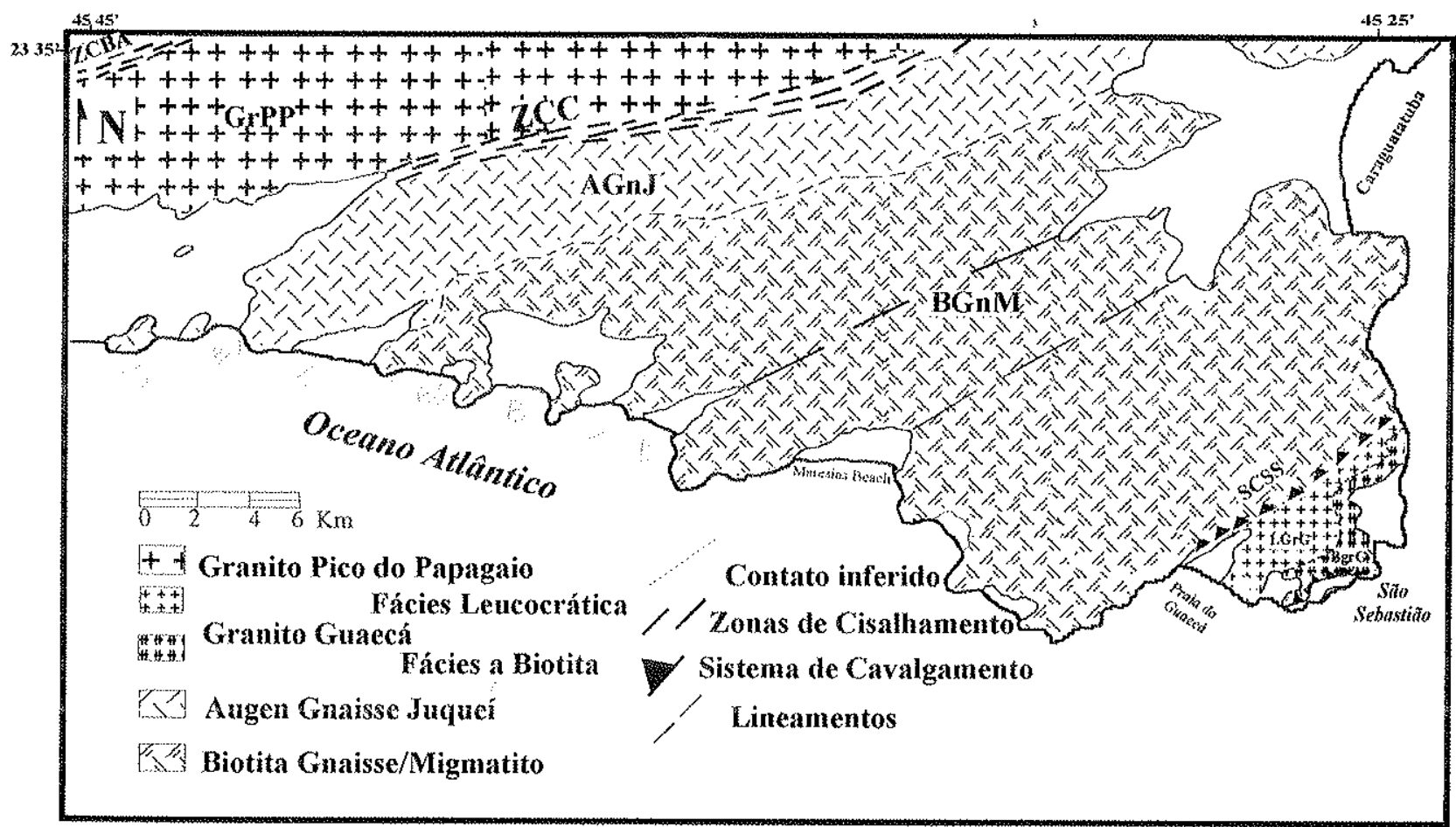

Figura 4.1 Mapa Geológico Geral. ZCBA = Zona de Cisalhamento Bairro do Alto; ZCC = Zona de Cisalhamento Camburu; SCSS $=$ Sistema de Cavalgamento São Sebastião; GrPP = Granito Pico do Papagaio; AGJ = Augen Gnaisse Juqueí CGM= Complexo Gnaissico / Migmatítico; GrGL = Granito Guaecá fácies Leucocrática; GrGB = Granito Guaecá fácies a Biotita; $\mathrm{SNC}=$ Sedimentos não Consolidados. 


\section{2 - Granito Pico do Papagaio}

O Granito Pico do Papagaio é um monzogranito com foliação bem desenvolvida. Mostra variação forte na intensidade de deformação refletida, no fabric, que varia de milonítico, nas zonas de cisalhamento, para uma textura equigranular nas partes internas do plúton.

Localmente contém enclaves decimétricos de hornblenda-gnaisse.

Assembléia mineral do Granito Pico do Papagaio é composta por quartzo, microclineo, plagioclásio, biotita e hornblenda.

Tassinari (1988) datou pelo método K-Ar, um (hornblenda) biotita granitóide porfirítico, na região de Caraguatatuba, o qual corresponde à extensão do Granito Pico do Papagaio ao norte, obtendo idade de $543^{+-} 16 \mathrm{Ma}$. Baseado nos resultados obtidos por Campos Neto e Figueiredo (1995) para granitos com características composicionais e geométricas similares ao Granito Pico do Papagaio, este plúton pode ser interpretado como sin a tardi colisional.

A figura 4.2 ilustra o fabric do Granito Pico do Papagaio.

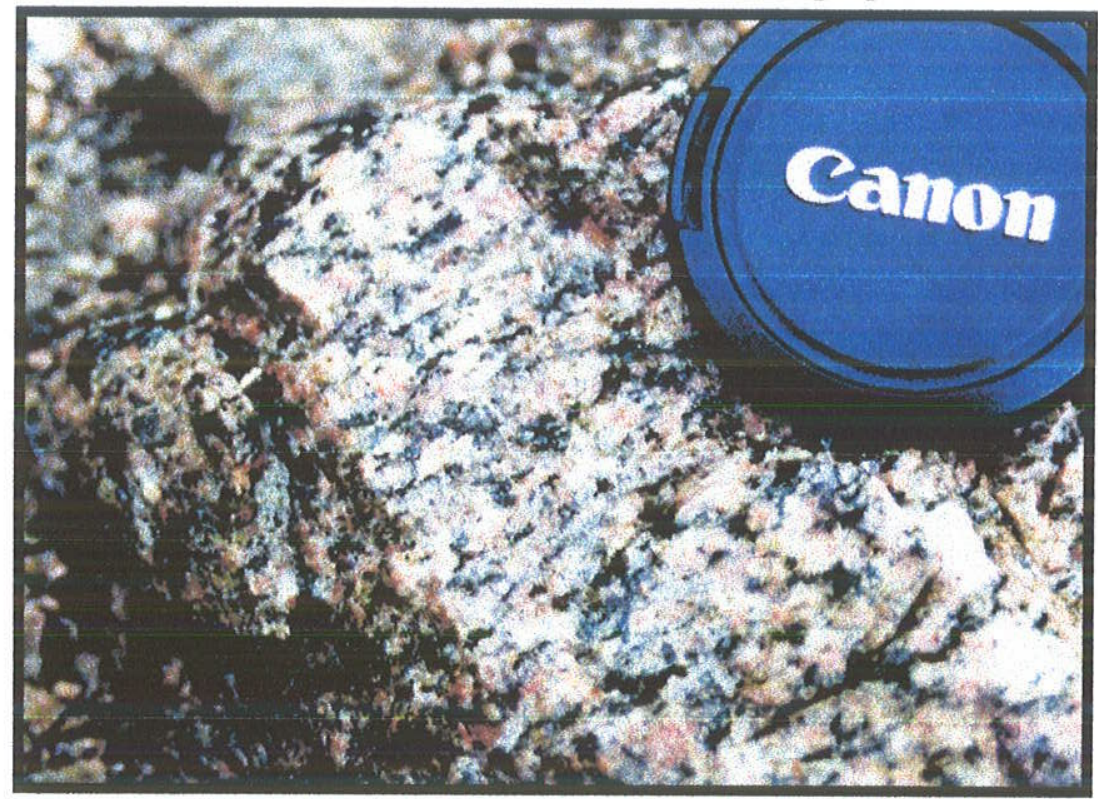

Figura 4.2 - Granito Pico do Papagaio. 
O contato com o Augen Gnaisse Juqueí é tectônico e ocorre ao longo da Zona de Cisalhamento Camburu.

\section{3 - Augen Gnaisse Juqueí}

Com aproximadamente $8 \mathrm{~km}$ de extensão a unidade de augen gnaisse está exposta no vale do rio Camburu, onde encontra-se em contato tectônico com o Granito Pico do Papagaio.

Composicionalmente o augen gnaisse é um álcali - feldspato granito. Os augens são principalmente de microclíneo. A matriz é composta por quartzo e microclíneo. Biotita ocorre em 10 a 15\%. A porcentagem de muscovita é inferior a $5 \%$ e ocorre principalmente associada a biotita. Apatita, ilmenita e zircão são minerais assessórios.

Próximo a Zona de Cisalhamento Camburu ocorrem algumas intercalações de anfibolitos.

Em seç̧ãomdelgada foi possível identificar inclusões de carbonato nos cristais de microclíneo. O augens mostram extinção ondulante. Envolturas ao redor deles formam uma foliação de quartzo recristalizado e faixas de feldspato. Na matriz os minerais são principalmente poligonais devido à recristalização. Esta bimodalidade indica a ocorrência de recristalização dinâmica parcial, provavelmente associada a temperaturas altas e presença de fluidos. Microtexturas comuns são mirmequitas e pertitas. As mirmequitas crescem ao longo dos limites dos augens de K-feldspato com orientação perpendicular à foliação (figura 4.4). Isto pode representar a direção de encurtamento e pode indicar eles foram formados em temperaturas altas (Passschier \& Trouw, 1996). Localmente tiras monominerálicas de quartzo ocorrem e criam uma aparência bandada. Elas apresentam extinção ondulante e bandas 
deformadas (deformed bands), uma fase transicional entre extinção ondulante e limite de subgrão.

Cloritização parcial de biotitas e o saussuritização de plagioclásios sugerem retrometamorfismo.

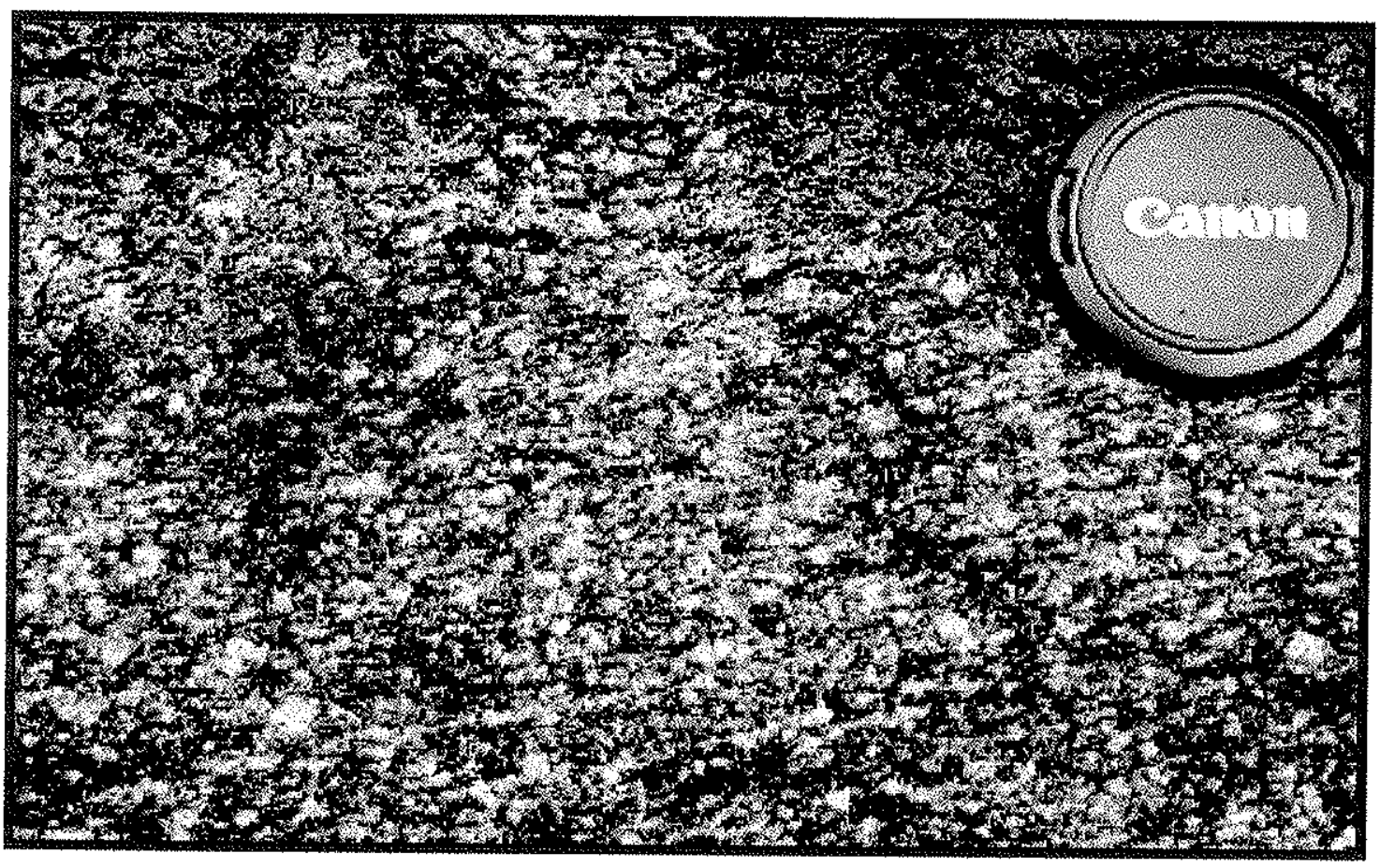

Figura 4.3 -... Augen Gnaisse Juqueí 

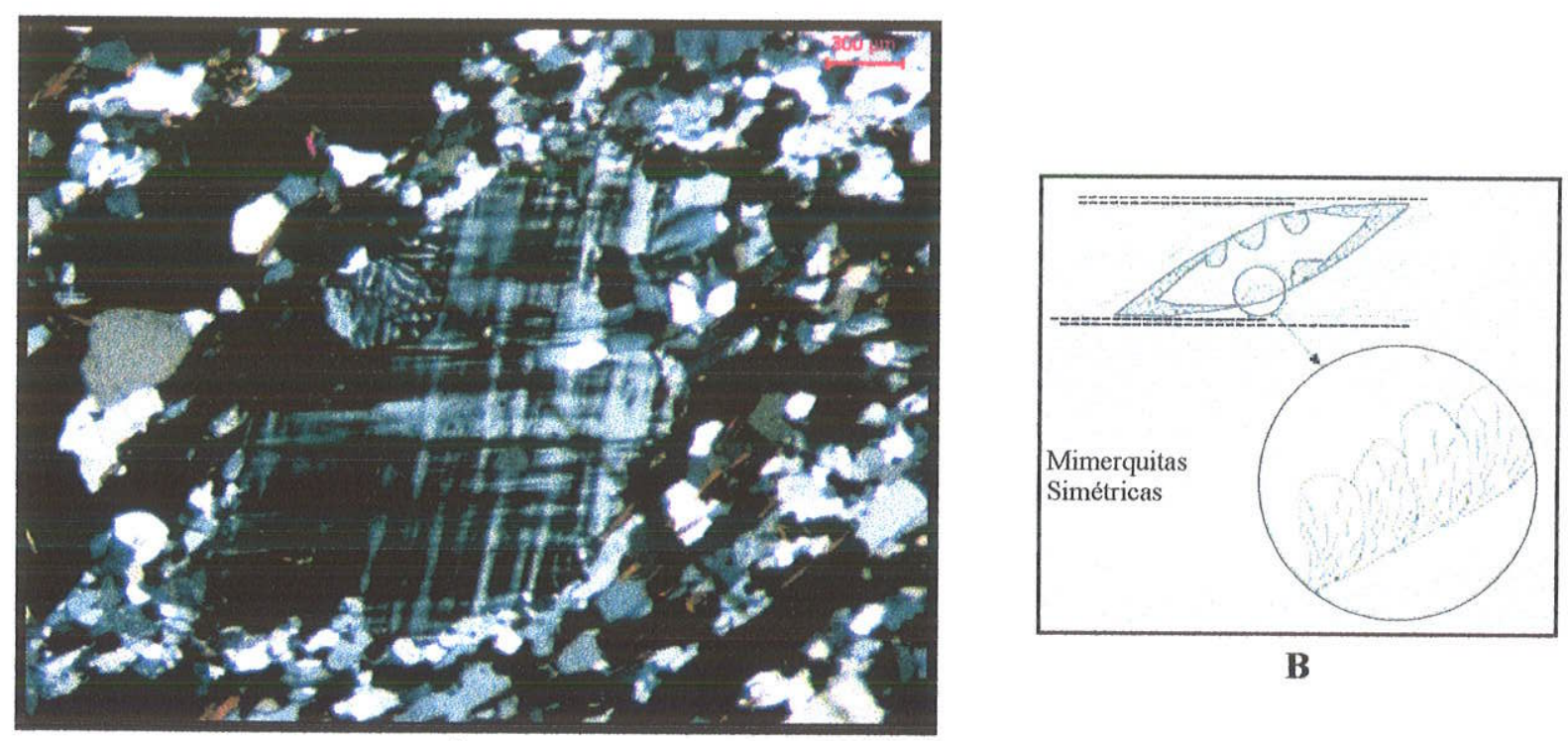

B

A

Figura 4.4 - Em A - seção delgada com nicóis cruzados. Mirmequitas crescem ao longo dos limites de Kfeldspato, Augen Gnaisse Juqueí. A orientação perpendicular à foliação sugere encurtamento nesta direção. Em B temos a descrição de como ocorre este processo em Passchier \& Trow (1996).

\section{4 - Complexo Gnáissico - Migmatítico}

O Complexo Gnáissico / Migmatítico ocupa cerca de $60 \%$ da área de estudo. Ocorre desde o contato transicional com a unidade de augen-gnaisse na praia de Juquei até a praia de Guaecá, onde está em contato tectônico com o Leucogranito Guaecá. Esta é a unidade mais heterogênea em termos de texturas e estruturas. Grada de um biotita gnaisse bandado a típicos migmatitos com texturas estromáticas e de nebulíticas.

Próximo ao contato com o Augen Gnaisse Juqueí a estrutura varia de schlieren para nebulítica e flebítica. Ao longo do contato com o Leucogranito Guecá, o qual ocorre em uma zona de cavalgamento, desenvolve-se um proeminente bandamento.

Em geral esta unidade apresenta textura granolepidoblástica com, granulação que varia de média a grossa. 
A assembléia mineral é composta por quartzo, biotita, muscovita, microclíneo, plagioclásio, sillimanita, granada e K-feldspato subhedral (com inclusões de quartzo, biotita e opacos). Localmente há ocorrência de cordierita. A foliação é formada pela orientação preferencial de biotita e muscovita e, quando também presente, através da sillimanita.

Biotita também ocorre como mineral secundário, em fraturas dos megacristais de K-feldspato.

Os contatos entre grãos são poligonais a interlobados e existe claramente bimodalidade. Ela é observada através da existência de megacristais subeuhdrais, com extinção ondulante, em uma matriz recristalizada de quartzo-feldspato euhedrais (figura 4.5). Isto pode ser interpretado como evidência de recristalização dinâmica parcial que poderia ser promovida por altas temperaturas e presença de fluidos.

Mirmequitas, intercrescimento de quartzo no plagioclásio com textura de vermicular, também ocorrem em uma proporção relativamente alta em limites de grão de K-feldspato, perpendicular à foliação. Eles podem ser associados com a deformação (strain) em rochas graníticas porque implicam em uma diminuição de volume. Desta forma os lados do álcali-feldspato com mirmequita indicariam a direção de encurtamento (Passchier \& Trouw, 1996).

Cloritização de alguns minerais como muscovita e biotita sugerem retrometamorfismo condições xisto verde.

Há porções enriquecidas em biotita e sillimanita, no caso em que a estrutura assume um aspecto xistoso. Numerosos enclaves de anfibolito ocorrem. Eles são mais evidentes quando o migmatito apresenta uma estrutura flebítica. Em textura estromática estes enclaves são paralelizados à foliação. 
Os enclaves também ocorrem como formas discordantes e tabulares. Em alguns casos eles correspondem a diques pré-cambrianos básicos que foram anfibolizados (IPT, 1992).

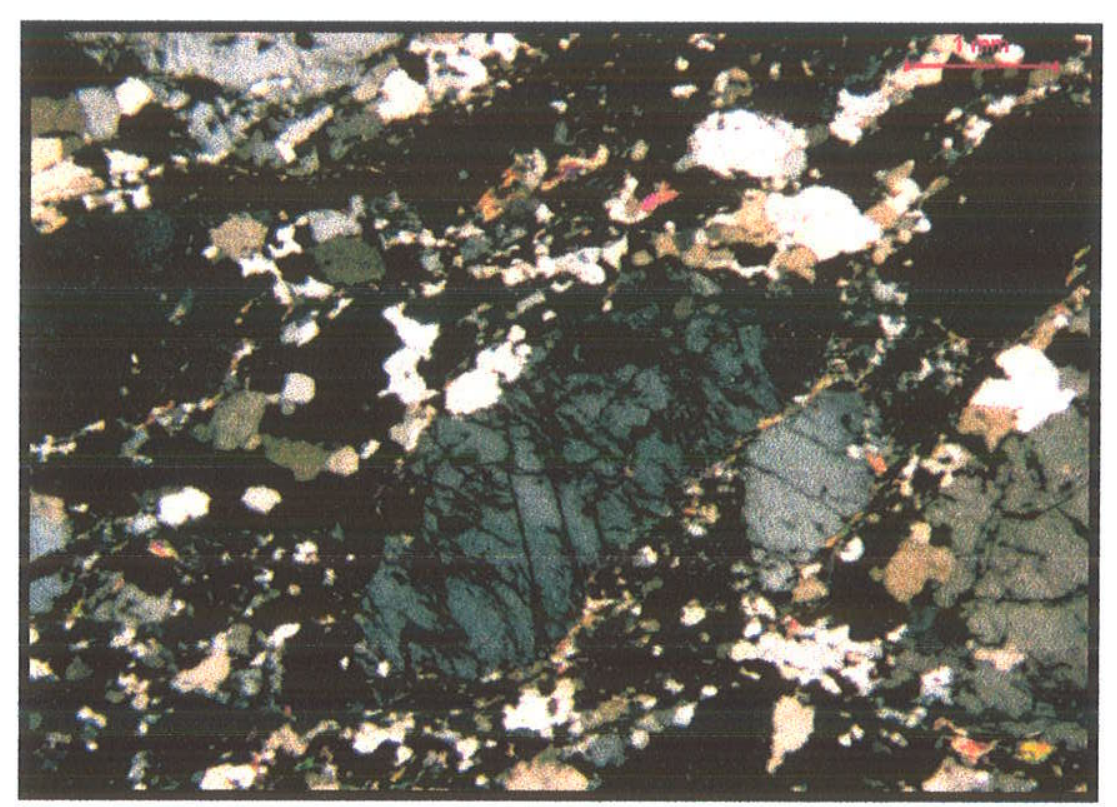

Figura 4.5 - Seção delgada, nicóis cruzados do Augen Gnaisse Juqueí. A alta porcentagem de recristalização é percebida através da ocorrência de grãos poligonais e bimodalidade dos grãos.

As figuras 4.6 e 4.7 ilustram as principais estruturas migmatíticas encontradas no Complexo Gnáissico -Migmatítico.

\section{5 - Granito Guaecá}

Esta litologia ocorre na parte do sudeste da área em estudo como um sheet granítico entre duas zonas de cavalgamento do Sistema de Cavalgamentos São Sebastião (SCSS). Estende-se desde as praias de Guaecá e Arrastão até a praia de Baraqueçaba e o bairro Topolândia (figura 4.1).

Composicionalmente, corresponde a um monzogranito a granodiorito, com quartzo, plagioclásio, microclíneo, biotita, muscovita e granada. 
O Granito Guaecá pode ser dividido em duas fácies: uma, leucocrática com granada, e outra, enriquecida em biotita.

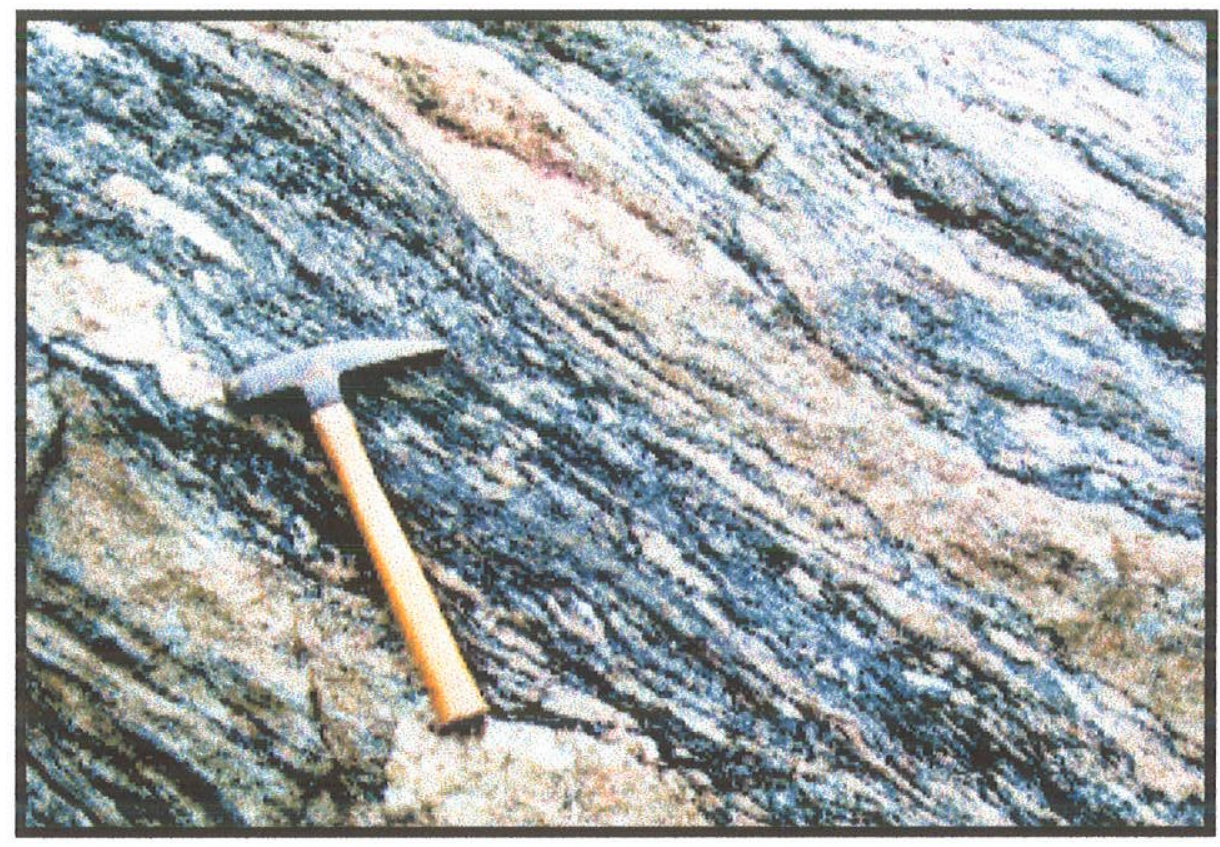

Figura 4.6 - Complexo Gnáissico-Migmatítico, estrutura estromática, Praia do Toque - Toque.

ce.

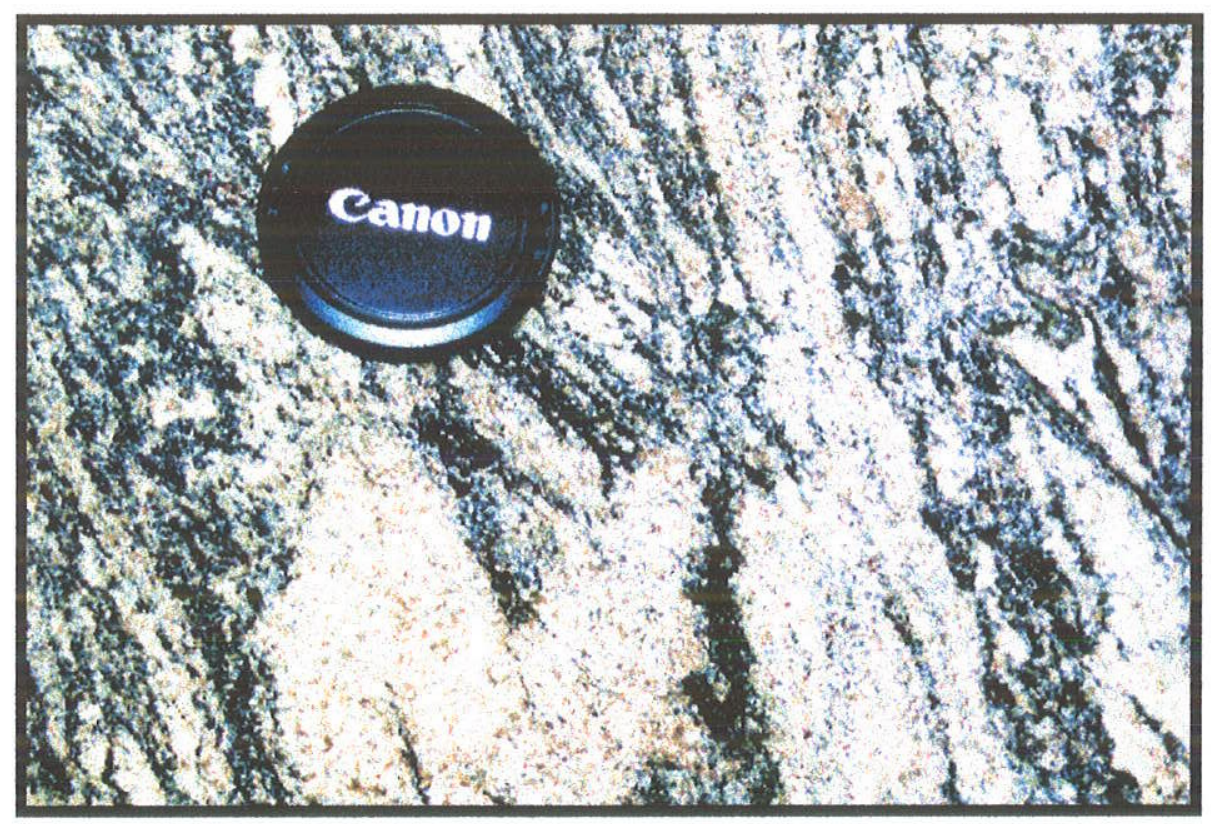

Figura 4.7 - Complexo Gnáissico - Migmatítico, estrutura nebulítica, praia da Paúba. 


\subsubsection{Fácies Leucocrática com granada}

A fácies leucocrática com granada corresponde a uma rocha com textura inequigranular e com bordas de grão interlobatas e poligonais. A maioria dos grãos tem forma subeuhedral a aneuhedral.

A ocorrência de grãos pequenos e grãos grandes com extinção ondulante sugere recristalização dinâmica parcial.

Mirmequitas, pertitas e micropertitas também são comuns e são formadas por exsolução e substituição mineral.

Próximo ao contato superior esta litologia apresenta uma textura grossa com mega cristais de K-feldspato. Em seção delgada eles foram identificados como microclineos com inclusões de plagioclásio e quartzo gerando uma textura poiquiloblástica.

A parte central do corpo tende a apresentar textura equigranular média e foliação mais intensa. A foliação varia em intensidade, mas ocorre em todo o corpo. Em seção delgada a foliação não é muito evidente e só é indicada pelo estiramento do quartzo e orientação preferencial das micas. Em escala 1:25.000 (Anexo 1) foi possível diferenciar uma fácies distinta rica em biotita: a fácies biotita.

O Leucogranito Guaecá não foi datado até o presente momento. Assim a única possibilidade é correlacioná-1o com o contexto tectônico regional, que sugere provavelmente idade cambriana inferior. 


\subsubsection{Fácies a Biotita}

Com a mesma composição geral da fácies leucocrática com granada, a fácies a biotita apresenta $10 \%$ a $15 \%$ de aumento de biotita e contato transicional. A fácies a biotita tem sua distribuição na parte externa do corpo, e em geral ocorre cavalgando sobre a unidade do Complexo Gnáissico/Migmatítico. Ao longo deste contato ocorre uma zona milonítica extensa. Veios de quartzo próximo ao contato sugerem mobilização de $\mathrm{SiO}_{2}$, que pode ser explicada pela intensificação da deformação (strain).

$\mathrm{O}$ anexo 1 corresponde ao mapa geológico em escala 1:25.000 da área correspondente a cidade de São Sebastião, onde o Sistema de Cavalgamentos São Sebastião ocorre. Nesta escala foi possível identificar a fácies a biotita do Granito de Guaecá.

As figuras 4.8 e 4.9 ilustram o Granito Guaecá em suas duas fácies, a leucocrática e a biotita.

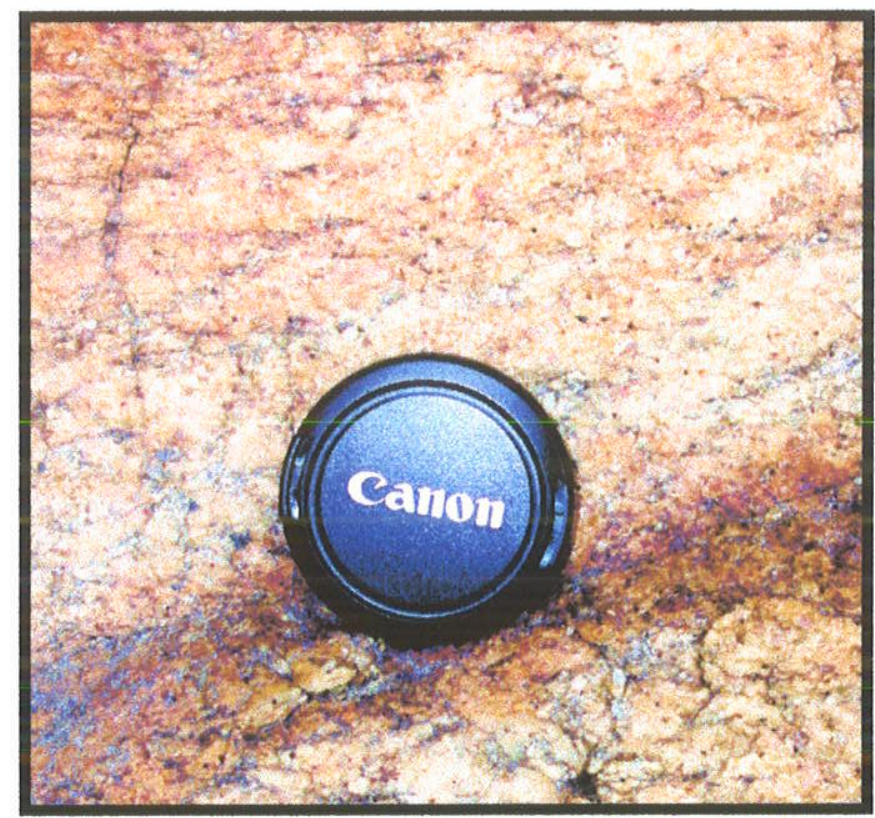

Figura 4. 8 - Granito Guaecá fácies leucocrática, praia do Guaecá. 


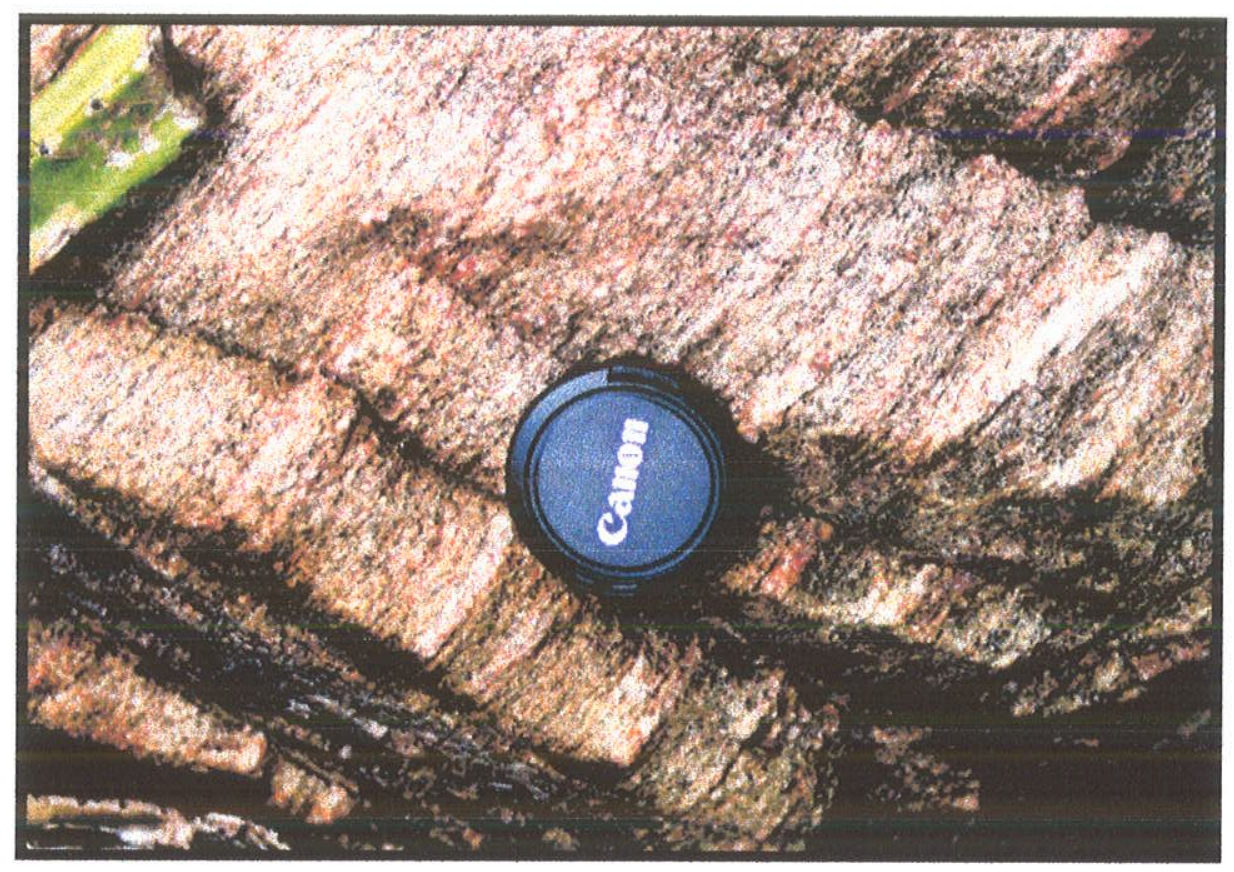

Figura 4.9 - Granito Guaecá fácies a biotita, praia do Zimbo.

A ocorrência da fácies a biotita na porção mais externa do corpo granítico pode ser reflexo do processo de deformação.

Na cidade de São Sebastião, onde a zona milonítica está exposta, uma faixa de 25 metros de augen gnaisse ocorre associada aos milonitos, ao longo do contato do Granito Guaecá, fácies a Biotita, e a unidade Gnaissico - Migmatítica. Esta ocorrência de augen-gnaisse pode corresponder a uma variação de textura da fácies a biotita diante do aumento da deformação.

\section{$\underline{4.6}$ - Metamorfismo}

A assembléia mineral presente aponta para grau metamórfico anfibolito, o qual parece ser homogêneo em toda área de estudo. 
Segundo Passchier, Myers \& Kröner (1993) terrenos gnáissicos podem apresetnar caminhos de pressão e temperatura muito complexos.

Como mostra a figura 4.10 A o caminho de pressão e temperatura alcançado em condições metamórficas de alto grau é representado pela linha cinza porém as partes preservadas encontram-se em preto. Desta forma não se torna difícil supor que a paragênese mineral encontrada na área de estudo possa refletir somente uma parcela deste caminho P-T.

Em geral, nas rochas gnáissicas/ migmatíticas da área em estudo uma paragênese comum de se observar é a dada por: sillimanita + granada + cordierita + plagioclásio + quarzto e por vezes $\mathrm{k}$ feldspato (figura $4.10 \mathrm{~B}$ ).

Esta associação mineral sugere uma origem paraderivada para estes gnaisses.

Em geral o metamorfismo em rochas pelíticas ocorre primeiro com a quebra da muscovita, seguida pela associação biotita + sillimanita + quartzo. A associação biotita+ sillimanita indica faixa de mais baixa temperatura do metamorfismo de alto grau ( Passchier, Myers \& Kröner, op. cit.).

É interessante observar que em condições de pressão mais elevadas a granada substitui a cordierita gradualmente porém a coexistência estável de $\mathrm{k}$-feldspato + sillimanita indica condições de pressões intermediárias (Passchier, Myers \& Kröner, op. cit.).

A ocorrência local de sillimanita na unidade Gnaissico - Migmatítica indica que o metamorfismo alcançou temperaturas superiores a $500^{0} \cdot \mathrm{C}$. A zona da sillimanita (sillimanita, K-feldspato, granada, biotita, quartzo, muscovita, plagioclásio) é o resultado da quebra da muscovita e conseqüente formação do Kfeldspato, como indica a reação a seguir:

$$
\text { musc }+\mathrm{qtz}=\mathrm{k} \text {-feld }+ \text { sillimanita }+\mathrm{H}_{2} \mathrm{O}
$$


Neste caso, a formação da sillimanita pode coincidir com a formação dos migmatitos porque a formação de água contribui para a redução da temperatura de fusão (Shelley, 1993).

Yardley (1989), em um estudo detalhado, associa o desenvolvimento de migmatitos um pouco abaixo da isógrada da sillimanita, definida pela reação acima descrita.

Outra feição observada é a cloritização parcial da biotita e a saussuritização do plagioclásio no Augen Gnaisse Juqueí, cloritização da muscovita e da biotita no Complexo Gnáissico/Migmatítico e cloritização da biotita e granada no leucogranito o que sugere retrometamorfismo em fácies xisto verde.

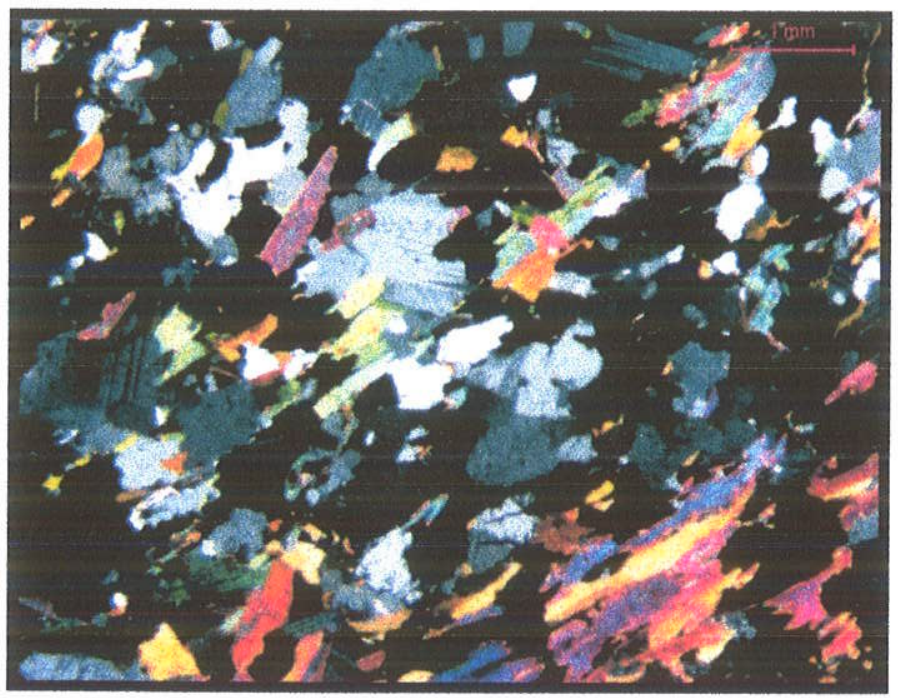

B

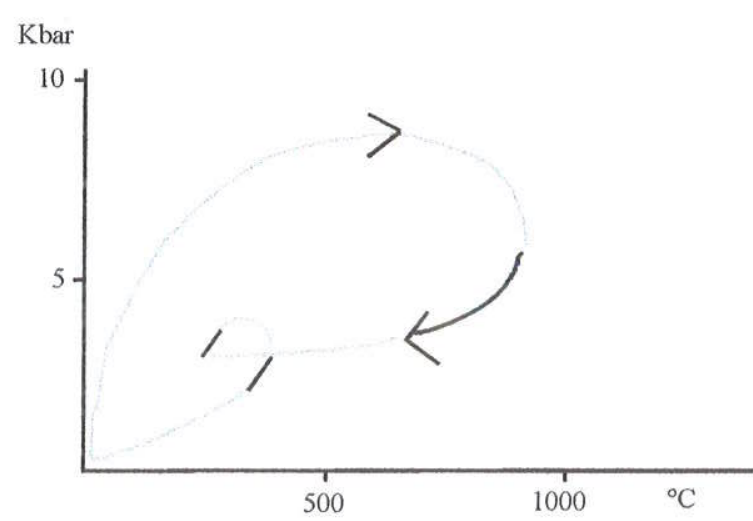

A

Figura 4.10 - Em A temos o gráfico que descreve o caminho que P-T percorrem em terrenos gnáissicos (Passchier, Myers \& Kröner, 1993). Em B temos uma paragênese genérica da área de estudo .

\section{7 - Diques}

Durante o período Juro - Cretácico a área foi afetada por intensa atividade magmática relacionada a abertura do Oceano Atlântico (Garda \& Schorscher, 1994). 
A atividade magmática gerou rochas de caráter toleítico (diabásios e microdioritos) e de caráter alcalino (lamprófiros).

Com orientação general N50E, os diques de diabásio são afaníticos ou de granulação fanerítica fïna com algumas porções internas de grã grossa.

Com augita titanifera, labradorita, magnetita e hiperstênio, eles apresentam às vezes margens esfriadas com formação de vidro vulcânico. $O$ microdioritos têm textura porfirítica com fenocristais centimétricos de plagioclásio e augita, quartzo, hiperstênio e feldspato na matriz.

Os diques de lamprófiros também têm orientação geral N50E. Eles ocorrem principalmente entre as cidades de São Sebastião e Caraguatatuba. Com texturas afanítica ou porfiritica, neste último caso apresentam fenocristais centimétricos de piroxênio e de olivina e "buracos" onde a remoção da olivina deu um aspecto poroso à rocha.

Em geral as litologias encaixantes mostram um intenso fraturamento paralelo ao contato dos diques.

De acordo com Garda (1995) na praia de Guaecá ocorrem traquitos provavelmente associado às colocação das rochas alcalinas da Ilha Bela.

Uma colocação de componentes distintos do manto é atribuído para a geração destas litologias. Os diques de diabásio são relacionados ao magmatismo da Bacia do Paraná que ocorreu há 130 Ma e os lamprófiros ao evento de magmatismo alcalino que aconteceu ao redor $80 \mathrm{Ma}$ (Garda, 1995).

\section{8 - Sedimentos não Consolidados}

Embora o estudo dos sedimentos não consolidados não tenha sido o objetivo desta tese mas, considerando-os como parte da litologia da área em estudo cabe uma breve descrição dos mesmos. 
Os sedimentos não consolidados ocupam áreas das grandes planícies do litoral, sendo que na área em estudo a maior é a planície litorânea de Caraguatatuba (figura 4.1). São de idade cenozóica e incluem: sedimentos marinhos pleistocênicos da Formação Cananéia, sedimentos marinhos holocênicos, sedimentos fluviolagunares holocênicos; e sedimentos continentais, aluvionares e associados a encosta (IPT, 1992).

Os sedimentos marinhos pleistocênicos pertencentes a Formação Cananéia são constituídos por areias marinhas e são encontrados somente em porções mais elevadas da planície litorânea de Caraguatatuba (IPT, op. cit.).

Sedimentos marinhos holocênicos são constituídos principalmente por areias marinhas que são distribuídas ao longo da linha de costa. Depósitos holocênicos continentais podem ser subdivididos em aluvionais e depósitos associados à encosta. Em algumas áreas eles cobrem depósitos marinhos mais velhos. Os depósitos aluvionais ocorrem ao longo das planícies litorais maiores (Caraguatatuba, Maresias, Camburi) e em áreas pontuais no planalto do Juqueriquerê. Eles são principalmente formados por areias de granulação grossa, e seixos de diferentes litologias do embasamento cristalino. Estes depósitos ocorrem principalmente ao longo das drenagens.

Alguns depósitos aluvionais antigos foram encontrados. Eles formam terraços fluviais areias imaturas em altitudes com 3 ou 4 metros mais elevados que os terraços atuais, e também apresentam um nível compacto de argila.

Os depósitos associados à encosta correspondem a depósitos de tálus e colúvios. Com uma granulometria variável apresentam em geral uma matriz arenosiltosa com seixos, blocos e matacões correspondentes a fragmentos de litologias do embasamento cristalino. 
Capítulo 5 


\section{Capítulo 5 - Geologia Estrutural}

\section{$\underline{5.1 \text { - Introducão }}$}

O Cinturão Ribeira estende-se mais de $1000 \mathrm{~km}$ ao longo da costa Atlântica do Sudeste do Brasil. Formou-se durante a assembléia do supercontinente Gondwana (750 - 500 Ma). Inclui zonas de cisalhamento transcorrentes, sistemas de cavalgamento, duplexes direcionais e estruturas em flor. Foi interpretados recentemente como um cinturão transpressivo (Ebert et al., 1993; Fragoso Cesar, 1993; Machado \& Endo, 1993; Wiedemann et al., 1996).

A área de estudo, localizada na parte do sudeste do Cinturão Ribeira, é transectada de oeste para leste pela Zona de Cisalhamento Bairro do Alto (ZCBA), Zona de Cisalhamento Camburu (ZCC) e pelo Sistema de Cavalgamento São Sebastião (SCSS).

Zona de Cisalhamento Transcorrente do Bairro Alto (ZCBA) tem orientação sudoestemordeste e afeta o granito Pico do Papagaio. Apresenta uma extensa e bem-desenvolvida foliação milonítica (figura 5.1).

A partir da Zona de Cisalhamento Bairro do Alto em direção ao leste a foliação passa a apresentar mergulhos de aproximadamente 40 a 60 graus para SE, e lineação mineral com caimento em ângulos altos, este comportamento aliado a indicadores cinemáticos sugere movimento na direção NW - SE.

Uma segunda zona de cisalhamento transcorrente, a Zona de Cisalhamento Camburu (ZCC), ocorre a $20 \mathrm{~km}$ a sudeste da Zona de Cisalhamento Bairro do Alto. Devido a seu caráter dúctil os limites da ZCC não são bem definidos. Uma zona de alta deformação com extensão de quase um quilômetro ocorre ao longo do vale do rio Camburu, seguida por uma zona de menor deformação, alguns quilômetros para o leste, onde a litologia dominante é augen gnaisse. 
A foliação assume atitude subvertical e o mergulho passa de SE para NW. Seguindo em direção leste, próximo ao vale do rio Maresias, a foliação começa a mergulhar com ângulos suaves a médios e as lineações mineral e de estiramento passam a apresentar orientação oblíqua a dip-slip.

$\mathrm{Na}$ praia de Guaecá ocorre o contato entre o Complexo Gnáissico/Migmatítico e o Granito Guaecá. O Granito Guecá ocorre na forma de sheet e é bordejado em ambos os lados por zonas de cavalgamento dúcteis pertencentes ao Sistema de Cavalgamentos São Sebastião (SCSS).

O SCSS contém duas zonas principais de cavalgamento, uma ocorre próximo a praia de Guecá e a outra próximo a cidade de São Sebastião. Estas "lascas" intercalam fatias do Complexo Gnáissico/ Migmatítico e do Granito Guaecá. As lineações neste sistema têm uma orientação oblíqua que, em conjunto com indicadores cinemáticos, sugerem transporte tectônico oblíquo para SSE.

Estruturas do tipo $\mathrm{S} / \mathrm{C}$ e porfiroclastos assimétrico são os indicadores cinemáticos mais frequentes na área de estudo. Foliação $\mathrm{S} / \mathrm{C}$ tende a formar-se em milonitos fracamente foliados, que contenham porcentagem pequena de mica (Passchier \& Trouw, 1996). S/C pode refletir heterogeneidade do cisalhamento simples e pode estar relacionado a fase inicial de geração do milonito.

A foliação $S$ é definida pela orientação preferencial das biotitas e faz ângulo baixo com a foliação $\mathrm{C}$ (de cisalhamento), normalmente também marcada pela biotita. Os microlitons são compostos principalmente por quartzo e feldspato.

Estruturas do tipo S/C são os indicadores cinemáticos mais comuns na área de estudo. Ocorrem tanto em macro como em micro escala e em litotipos diferentes. É um fabric muito comum em zonas de cisalhamento de médio - grau e em granitos deformados. 
Outro indicador cinemático muito frequente são os porfiroclastos assimétricos. Os mais freqüentes são do tipo $\phi, \sigma$ e $\delta$. Porfiroclastos do tipo $\phi$ tem cauda mas nenhum degrau; porfiroclastos do tipo $\sigma$ tem mantos largos próximos ao porfiroclasto e apresentam duas faces planas e duas faces curvas que definem sua assimetria; porfiroclastos do tipo $\delta$ tem caudas estreitas (ou asas) adjacentes ao porfiroclasto resultando no "embaiamento" da matriz (Passchier \& Trouw, 1996). Figura 5.2 ilustra estes tipos de porfiroclastos.

A figura 5.1 mostra o mapa estrutural esquemático da área estudada e os perfis transversais às principais estruturas. Também indica os cinco domínios estruturais definidos com base na variação do comportamento da foliação e lineações. Três destes domínios contém as zonas de cisalhamento e o sistema de cavalgamentos, outros dois domínios representam zonas de menor deformação.

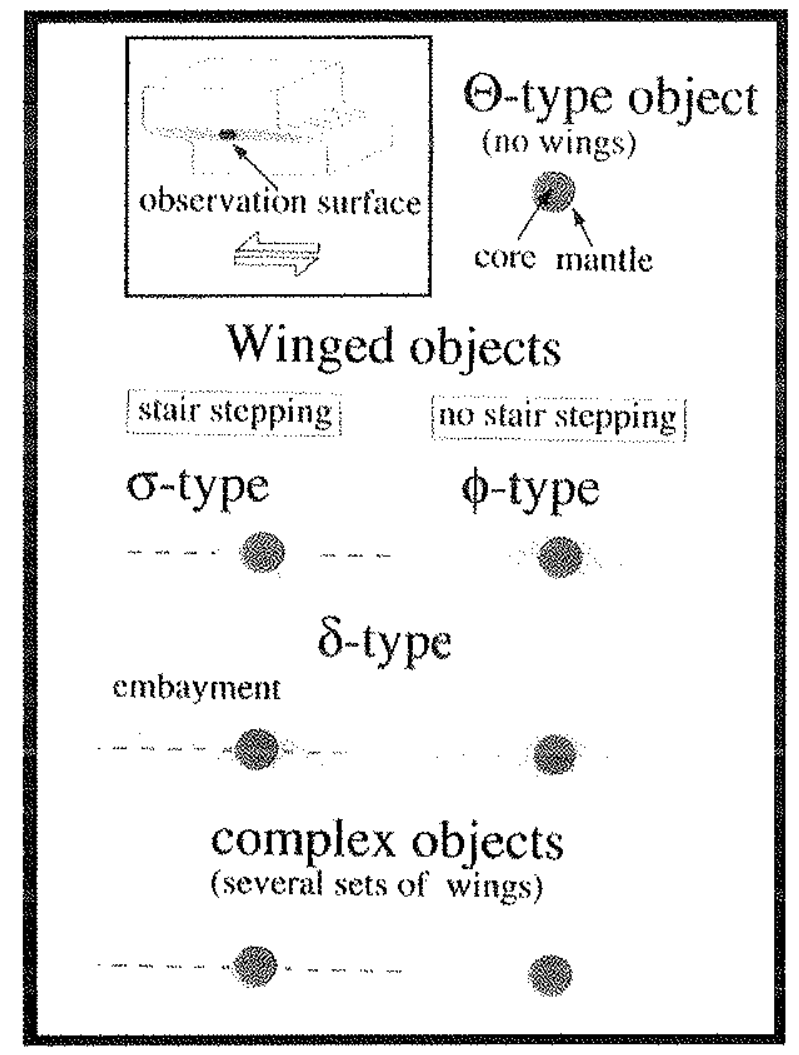

Figura 5.2 - Classificação de porfiroclastos. Neste caso com sentido de cisalhamento sinistral (Passchier \& Trouw, 1996). 


\section{2-Domínio Estrutural 1: Zona de Cisalhamento do Bairro do Alto}

A Zona de Cisalhamento do Bairro do Alto tem um caráter sinuoso regional. Estende-se ao longo da costa de São Paulo, desde a cidade do Guarujá até a cidade de Ubatuba, com uma extensão de cerca de $150 \mathrm{~km}$. Na área de estudo esta zona de cisalhamento ocorre na parte noroeste e bordeja o granito Pico do Papagaio a oeste.

A Zona de Cisalhamento Bairro do Alto é caracterizada por uma foliação milonítica sub-vertical. Apresenta lineações sub-horizontais que caem para NE. Os milonitos apresentam bandas milimétricas de quartzo e feldspato.

No extremo oeste da área em estudo, próximo a Capela São Lourenço, encontra-se a zona de maior deformação com ocorrência de ultramilonitos com poucos metros de largura.

O fabric é formado por quartzo-microclíneo e por menos de $5 \%$ de biotita. Hornblenda ocorre em uma porcentagem abaixo de 5\%. Esta assembléia mineral sugere o Granito Pico do Papagaio como protólito.

Embora os milonitos estejam fortemente recristalizados, em afloramento eles apresentam bandamento milimétrico quartzo-feldspático distinto (figura 5.3).

Em seção-delgada observa-se uma clara textura bandada com camadas formadas por quartzo recristalizado e microclíneo alternado com camadas de ribbons alongados de quartzo.

A porcentagem de grãos recristalizados é ao redor de $90 \%$, que de acordo com a classificação de Sibson (1977) está no limite entre o fabric milonítico e ultramilonítico.

A forma poligonal das bordas dos grãos e as junções tríplices sugerem migração de limite de grão, um processo de recristalização dinâmica (figura 5.4). 


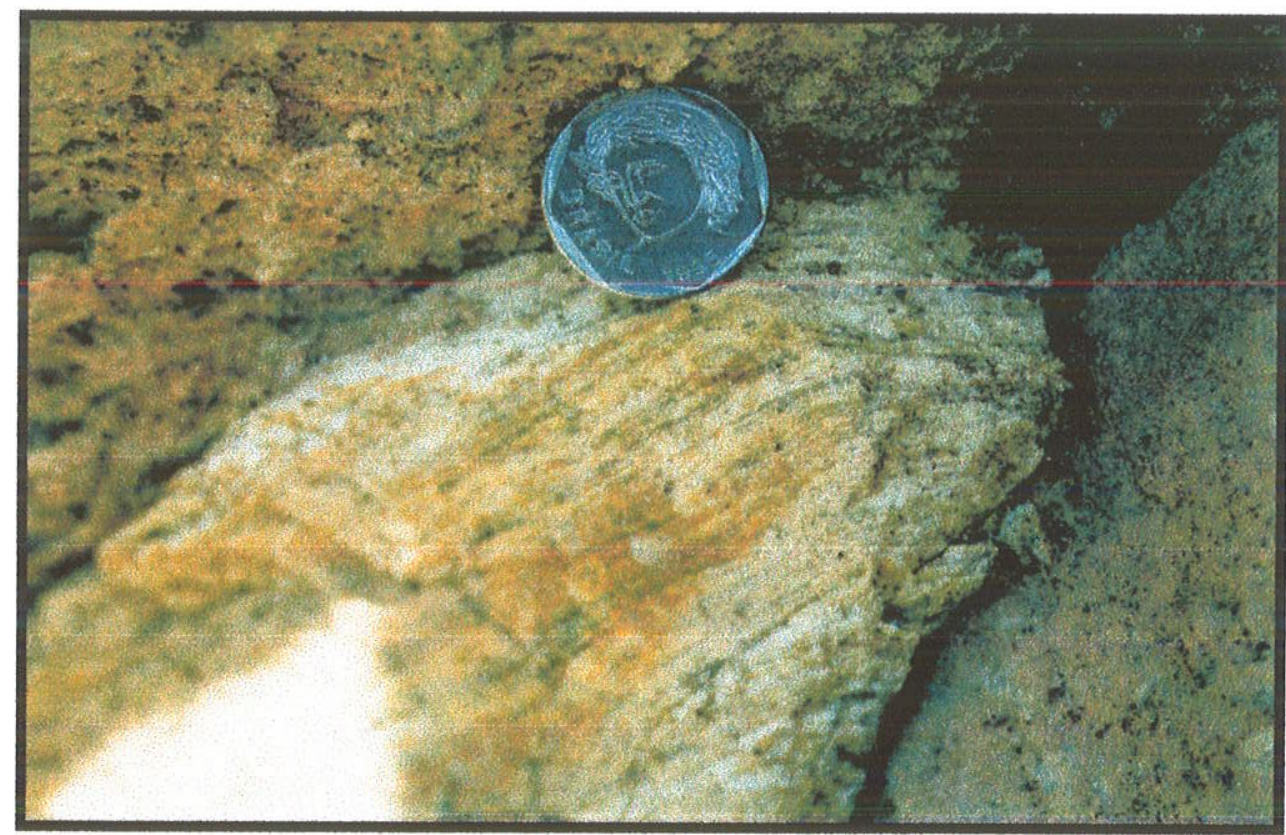

Figura 5.3 - Afloramento de milonito da Zona de Cisalhamento do Bairro do Alto. Este milonito tem como protólito o Granito Pico do Papagaio. Note o bandamento milimétrico distinto de quartzo e feldspato.

Este ultramilonito é interpretado como Stripped Gneiss, um fabric milonítico formado quando, em altas temperaturas, a diferença no comportamento reológico entre dois minerais diminue e inicia -se o processo de difusão (Passchier \& Trouw, 1996).

O resultado é uma textura bandada com alguns porfiroclastos e granulometria grossa (figura 5.5).

$\mathrm{Na}$ Zonas de Cisalhamento Bairro do Alto, foliações miloníticas com mergulho para SE e com lineações com caimento suave indicam movimento predominantemente direcional (strike-slip).

Como observado no estereograma (figura 5.6) na área onde a Zona de Cisalhamento Bairro do Alto ocorre, a foliação apresenta mergulhos altos (subverticais) para SSE e as lineações tem caimento suave para Leste indicando movimento oblíquo, mas predominantemente transcorrente. 


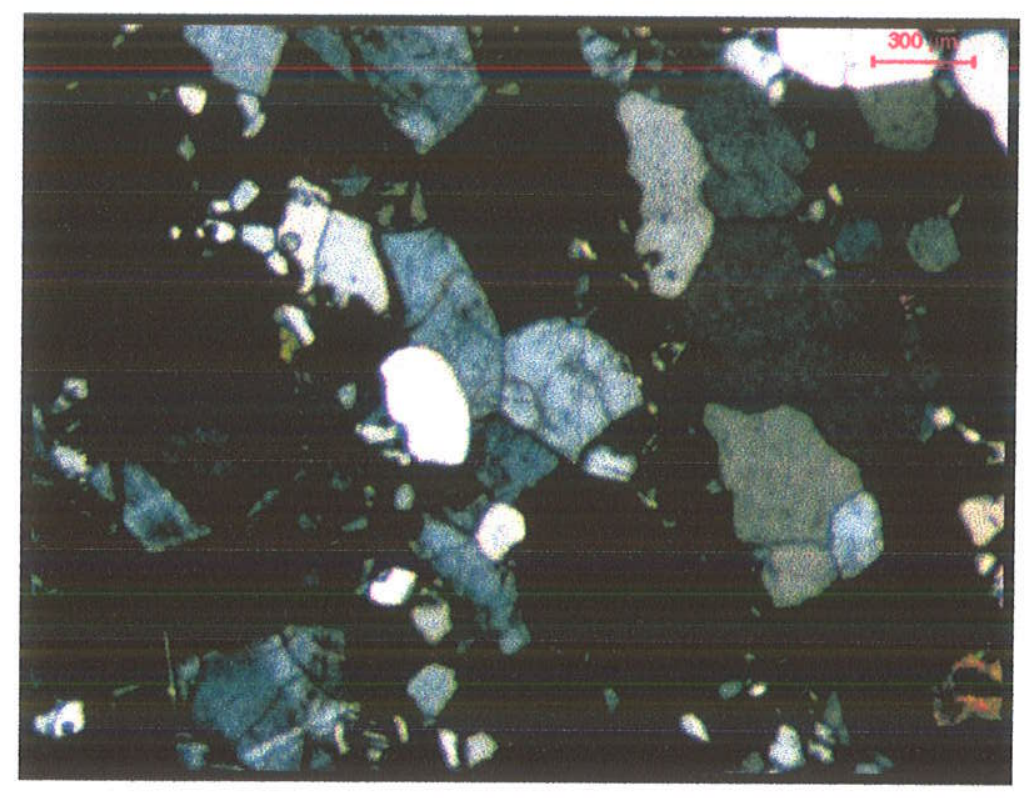

Figura 5.4 - Em seção delgada, nicóis cruzados, observa-se a forma poligonal das bordas dos grãos e as junções tríplices indicando processo de recristalização dinâmica.

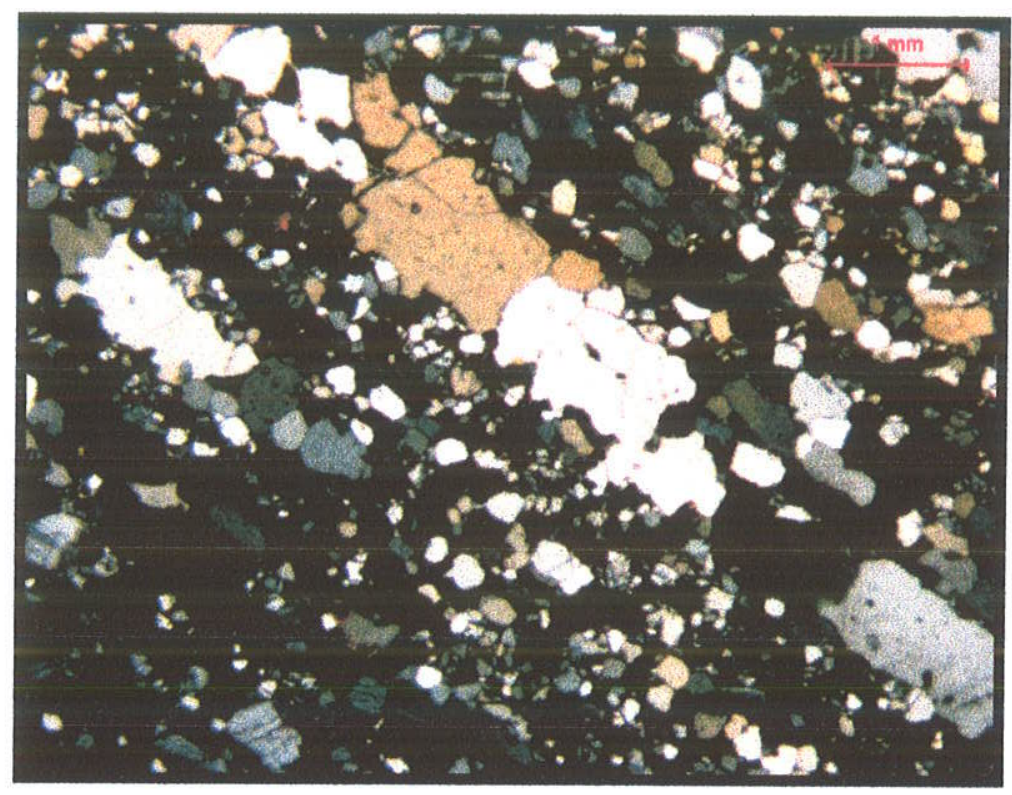

Figura 5.5 - Foto de seção delgada com nicóis cruzados. Stripped Gneiss. Zona de Cisalhamento do Bairro do Alto. Textura bandada com ribbons estirados de quartzo e quartzo recristalizado e microclina. Esta textura causa aparência de um fabric de granulação grossa. 


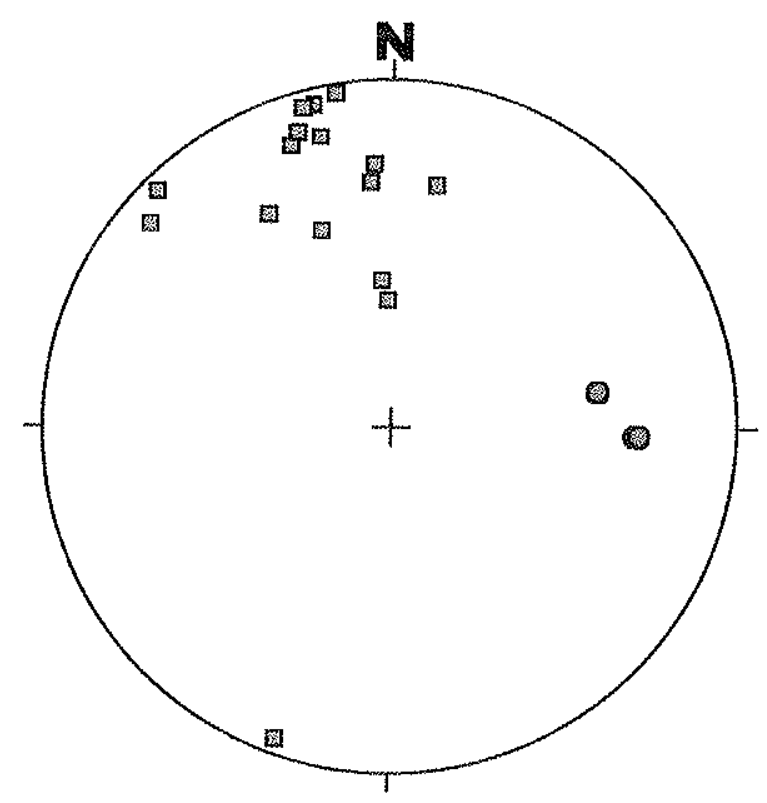

Z.C.Bairro do Alto

n. de dados: 19

Figura 5.6 - Estereograma com a projeção polar foliação (em quadrados cinza), e da lineação (em círculos vermelhos), na Z.C. Bairro do Alto.

\section{3-Domínio Estrutural 2: Entre a Zona de Cisalhamento do Bairro do Alto e} a Zona de Cisalhamento Camburu

Entre a Zona de Cisalhamento Bairro do Alto (ZCBA) e a Zona de Cisalhamento Camburu (ZCC) em direção ao leste, a foliação começa gradualmente a apresentar mergulhos suaves para SE em ângulos que variam de $60^{\circ}$ a $30^{\circ}$ (figura 5.7).

Nesta área, o fabric varia apresentando uma quase alternância de zonas mais deformadas (mais alto strain) e zonas menos deformadas.

A lineação mineral com orientação $\mathrm{SE}$ dip-slip (figura 5.7) aliada a indicadores cinemáticos, como um veio de quartzo deformado (figura $5.10 \mathrm{~A}$ ) e estruturas do tipo $\mathrm{S} / \mathrm{C}$ sugerindo a ocorrência de cavalgamento no sentido NW (figura $5.10 \mathrm{~B}$ ). 
As evidências deste cavalgamento ao contrário dos cavalgamentos que ocorrem próximo a São Sebastião, são mais discretas pois não apresentam um fabric milonítico intenso, nem estruturas como dobras em bainha, estas evidências baseiam-se na orientação das feições lineares e nos indicadores cinemáticos.

n. de dados: 7

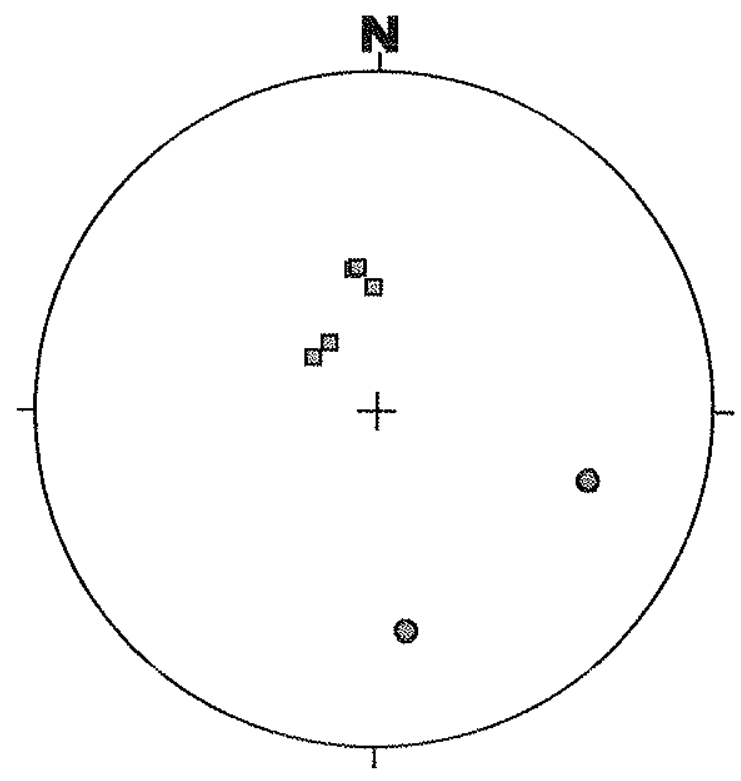

Figura 5.7 - Estereograma apresenta projeção polar da foliação (em quadrados cinzas) e lineação (círculos vermelhos) entre as zonas de cisalhamento Bairro do Alto e Camburu. Repare que os dados indicam ocorrência de cavalgamento neste domínio

\section{4-Domínio Estrutural 3: Zona de Cisalhamento Camburu}

A Zona de Cisalhamento Camburu tem sido reconhecida como uma falha transcorrente dextral com reativação durante Juro - Cretácico e Terciário (Campanha, Ens \& Ponçano, 1994).

Esta zona de cisalhamento tem orientação NE e pelo menos cem quilômetros em extensão. Na área de estudo a ZCC ocorre ao longo do vale do rio Camburu e desaparece debaixo dos depósitos quaternários da planície de Bertioga. 
Suas extremidades se ramificam. O ramo norte foi descrito como falha Bertioga - Caraguatatuba por Chieregati et al.(apud Campanha \& Ens, 1996) ou falha de Quinhentos Reis, por Melo e Pires Neto (apud Campanha \& Ens, op.cit., 1996).

Na área de estudo a ZCC ocorre ao longo do contato entre o Granito Pico do Papagaio e o Augen Gnaisse Juqueí. Ao longo da zona, o fabric reflete uma variação heterogênea do strain com a formação de protomilonitos, milonitos e ultramilonitos, sendo o protólito de difícil reconhecimento.

Esta zona exibe foliação subvertical (de 60 a 85 graus de mergulho para NW).

As lineações encontradas apresentam dois comportamentos distintos, o primeiro predominantemente dip-slip e transcorrente com componente obliquo (figura 5.8). Porém cabe salientar que as lineações com orientação dip-slip só foram observadas em um ponto, no costão da Praia da Juréia.

Dados: 41

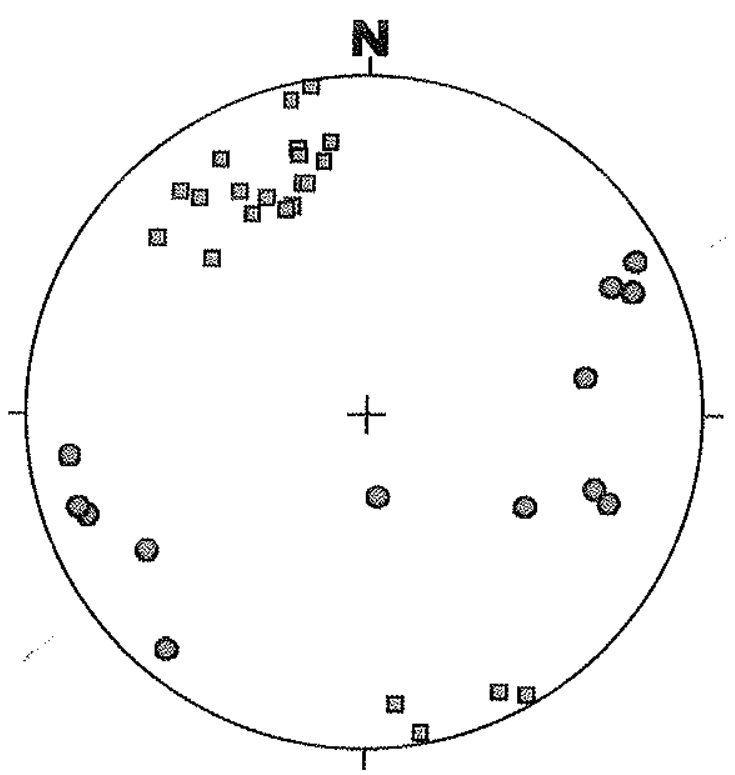

Figura 5.8 - Estereograma apresentando a projeção polar da foliação (em quadrados cinza) e da lineação (em círculos vermethos) na Z.C. Camburu. 
A zona milonítica apresenta uma largura de quase um quilômetro. Microestruturalmente estes milonitos apresentam textura granoblástica, bimodalidade devido a uma matriz com ao redor $50 \%$ de grãos novos, e camadas milimétricas de ribbons de quartzo (figura 5.9).

Junções tríplices são comuns nos grãos recristalizados sugerindo processo de recristalização dinâmica com redução de borda de grão. Devido à porcentagem alta de recristalização e à pouca porcentagem de micas (ao redor $5 \%$ de biotita e menos que $1 \%$ de muscovita), a foliação é pouco desenvolvida em escala de seção delgada, assim como os indicadores cinemáticos.

Estruturas do tipo $\mathrm{S} / \mathrm{C}$ e porfiroclastos assimétrico ocorrem com frequência.

Estruturas do tipo $\mathrm{S} / \mathrm{C}$ são os indicadores cinemáticos mais comuns na área de estudo. Ocorrem tanto em macro como em micro escala e em litotipos diferentes.

É um fabric muito comum em zonas de cisalhamento de médio grau e em granitos deformados.

No Sistema de Cavalgamentos São Sebastião (SCSS) estruturas do tipo S/C ocorrem em escala centimétrica nas camadas quartzo-feldspáticas e indicam movimento para SE.

No caso da Zona de Cisalhamento Camburu, estruturas do tipo S/C são encontradas com frequência ao longo da zona de maior deformação. Outra feição interessante é a ocorrência de uma faixa centimérica de clataclasito associado a reativação rúptil da zona.

Outro indicador cinemático muito frequente na Zona de Cisalhamento Camburu são os porfiroclastos assimétricos. Os mais freqüentes são do tipo $\phi, \sigma \mathrm{e}$ $\delta$. Alguns deles indicam movimentação sinistral (figura $5.10 \mathrm{C}$ ), outros indicam movimentação dextral (figura 5.10 D). Trabalhos prévios descrevem 
movimentação dextral como predominante na Zona de Cisalhamento Camburu (Campanha \& Ens, 1996).

Uma possível explicação para a ocorrência de porfiroclastos indicando ambos sentidos de movimentos é dada por Passchier \& Trouw (1996). Segundo os autores a ocorrência de ambos indicadores em uma mesma área pode ser explicada pelo movimento relativo dos porfiroclastos.

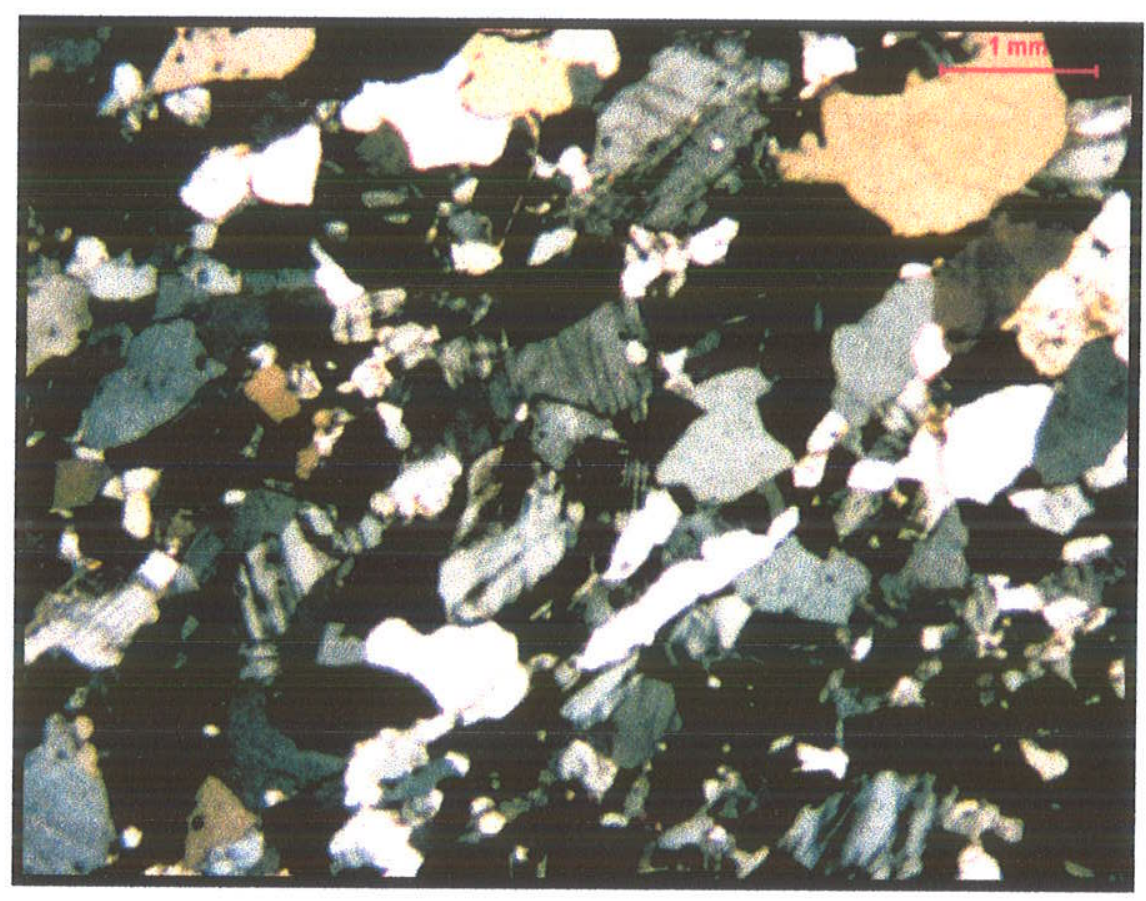

Figura 5.9 - Seção delgada do fabric milonítico da Zona de Cisalhamento Camburu. Observa-se a textura granoblástica, bimodalidade de grãos devido a uma matriz com cerca de $50 \%$ de grãos neoformados.

Uma outra possível explicação para a ocorrência de indicadores cinemáticos com diferentes sentidos seria a variação da velocidade de fluxo durante a deformação progressiva. Diferenças no gradiente da velocidade de fluxo produziriam vorticidades (vetor de velocidade angular) diferentes durante a deformação. Se o gradiente de velocidade se inverter, o sentido da vorticidade também se inverterá. 

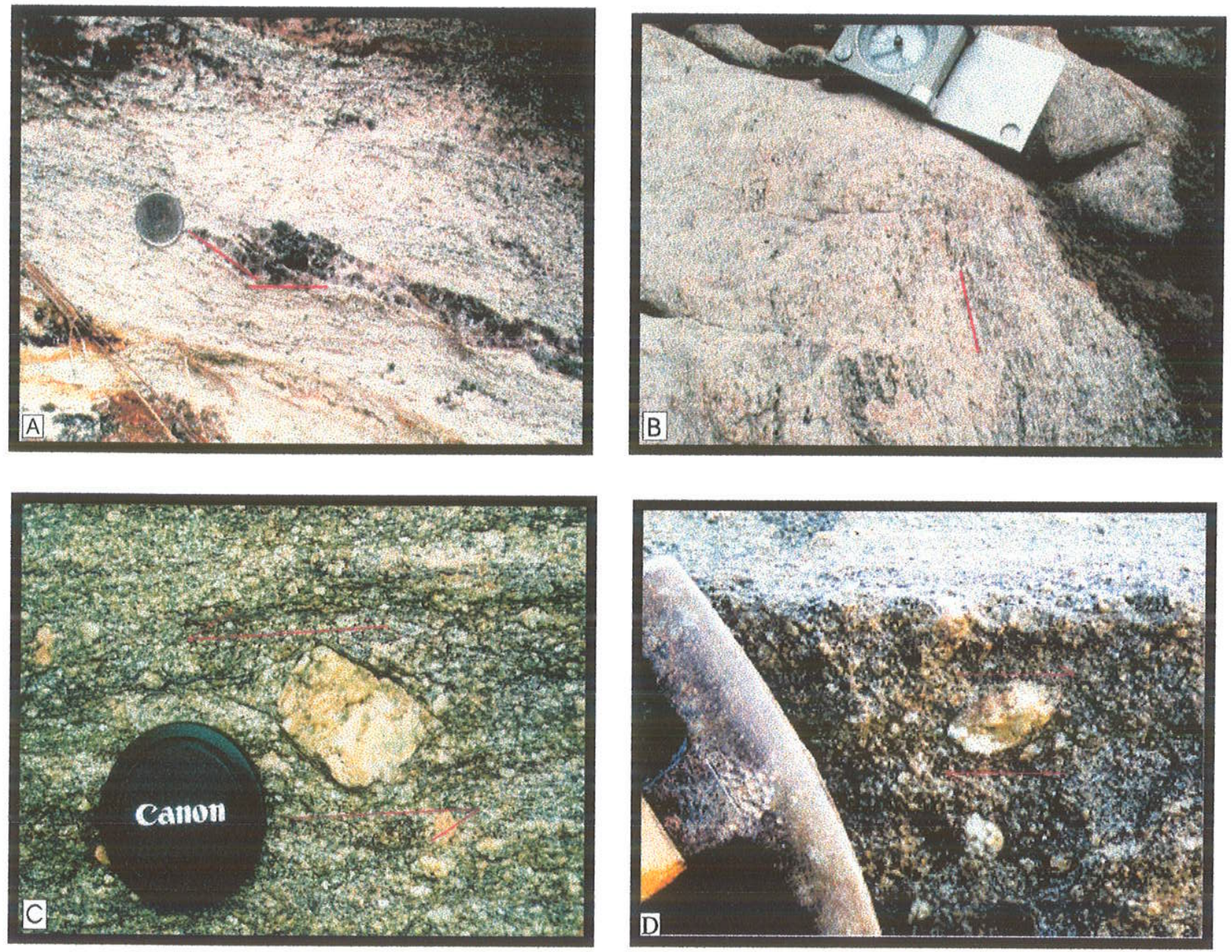

Figura 5.10 Papagaio.

A: Estruturas do tipo S/C em veio de quartzo, indicando cavalgamento para NW - Granito Pico do

B: Lineação de estiramento com orientação dip-slip - Zona de Cisalhamento Camburu

C: Porfiroclasto do tipo $\sigma$, indicando movimento sinistral - Zona de Cisalhamento Camburu.

D: Porfiroclasto do tipo $\sigma$, indicando movimento dextral - Zona de Cisalhamento Camburu. 


\section{5 - Domínio Estrutural 4: Entre a Zona de Cisalhamento Camburu e o Sistema de Cavalgamentos São Sebastião}

Entre a Zona de Cisalhamento Camburu e o Sistema de Cavalgamentos São Sebastião o fabric geral ainda sugere alta deformação com desenvolvimento de textura tipo augen gnaisse.

A foliação mantém-se subvertical porém seu mergulho muda de SE para NW. Um ponto interessante é que a mudança do sentido do mergulho não ocorre na zona de maior deformação, mas na zona onde a deformação é menor. Isto é evidente nos perfis PA-PA' e PB-PB' (figura 5.1).

A lineação de estiramento cai suavemente para SW e encontra-se lineações tanto direcionais (strike -slip) como dip - slip e oblíquas. A primeira orientação pode ser causada pela proximidade da Zona de Cisalhamento Camburu enquanto as demais orientações sugerem forte componente de cavalgamento para SE ou indicam ainda um componente elevado de cisalhamento puro.

O augens são principalmente de plagioclásio e ortoclásio com inclusões angulares de plagioclásio, muscovita e biotita (figura 5.11). A maioria destes augens poderia ser classificado como do tipo $\theta$, sem cauda presente. O tipo $\phi$ também é encontrado e algum porfiroclastos do tipo $\sigma$ sugerem movimento transcorrente dextral. Microestructuralmente a bimodalidade do fabric indica forte processo de recristalização dinâmica.

A partir da praia do Juqueí rumo a sudeste até a praia do Guaecá é encontrada uma zona de deformação mais homogênea. Esta área corresponde a ocorrência do Complexo Gnáissico- Migmatítico.

A foliação gnáissica e por vezes xistosidade passam de mergulhos subverticais para mergulhos medianos sempre para NW e apresentam lineação 
mineral com caimento suave. Indicadores cinemáticos sugerem movimento oblíquo com componente transcorrente dextral.

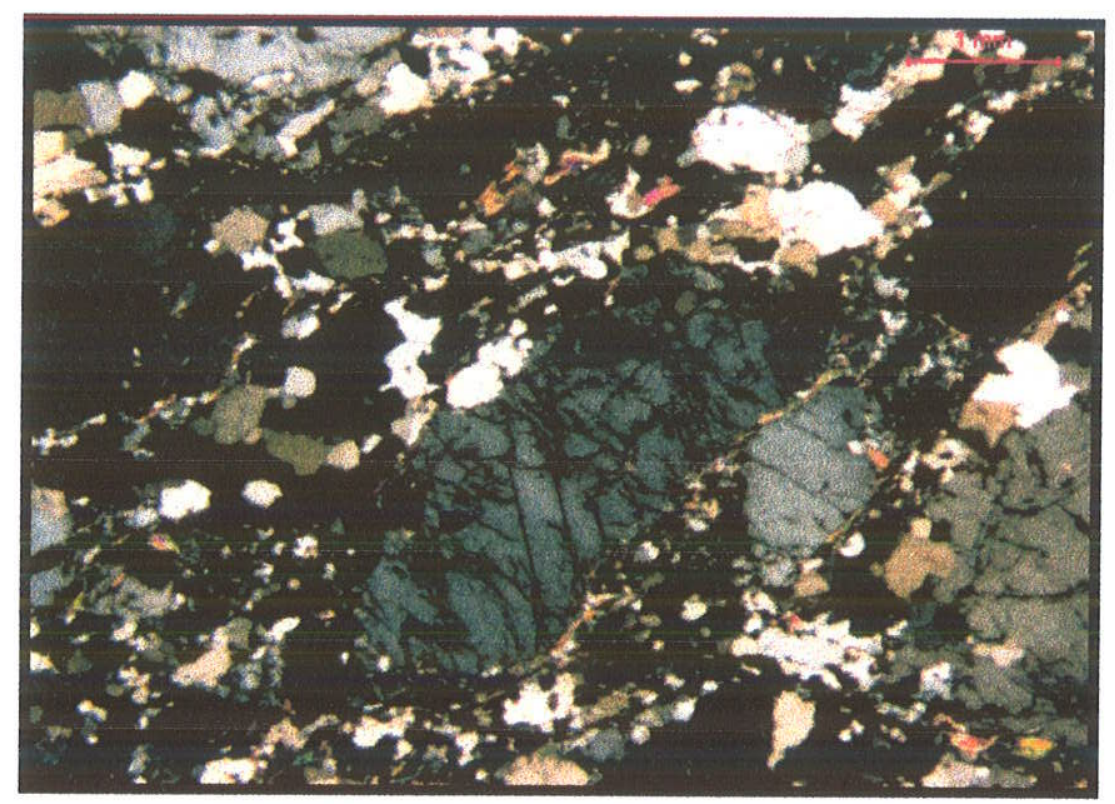

Figura 5.11 - Seção delgada Augen Gnaisse Juqueí. Desenvolvido próximo a Zona de Cisalhamento Camburu.

Uma característica estrutural comum nesta parte da área é a ocorrência de enclaves deformados. Eles são corpos sigmoidais assimétricos formados por anfibolitos ou pegmatitos com foliação interna paralela à foliação gnáissica externa. Estes corpos por vezes flexionam a foliação da matriz devido ao contraste na competência das litologias. Há casos que a foliação interna é discordante e até mesmo encontra-se dobrada (figura 5.13 B). Quando associado a porções de menor deformação estes corpos são subangulares na sua forma (figura $5.13 \mathrm{~A}$ ).

Boudins são segmentos lineares de uma camada que foi rompida ao longo de linhas periodicamente espaçadas (Twiss \& Moores, 1992). Eles se formam durante deformação quando há um componente de estiramento paralelo a camada competente em uma matriz incompetente.

Os xenólitos deformados são distintos dos boudins porque eles não são segmentos lineares. Eles são blocos métricos isolados, assimétricos e às vezes 
subangulares na forma. Normalmente estão associado a porções com menor deformação mas quando localizados em porções com maior intensidade de deformação, são estirados e é quase impossível a reconhecê-los.

Estruturas do tipo pinch-and-swell também são comuns neste domínio. Elas são oscilações suaves nas espessuras de uma camada e formam-se quando a diferença em competência de duas camadas é muito pequena para gerar boudinage. Ocorrem principalmente nos pegmatitos e em níveis anfiboliticos paralelos à foliação principal (figura 5.12).

Próximo ao Sistema de Cavalgamento São Sebastião, na área que vai da praia de Santiago para a praia Brava, a litologia assume estrutura bandada. Esta é a área onde o biotita gnaisse e migmatitos de textura estromatítica predominam.

Nesta área a foliação mergulha NW num ângulo que varia entre 30 e 40 graus. Lineações de estiramento e mineral indicam movimento desde direcional a quase perfeito dip -slip.

S/C também ocorre no contato entre o Complexo Gnaissico-Migmatítico e o Granito Guaecá, associado a zonas de maior deformação.

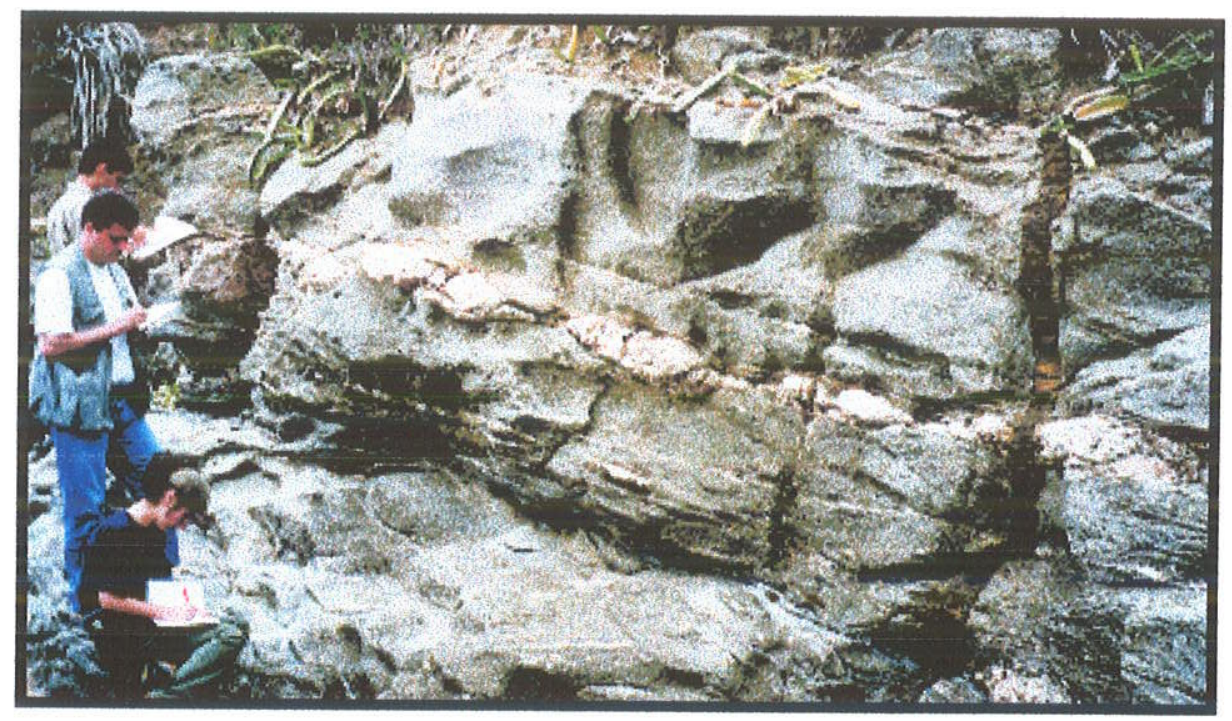

Figura 5.12 - Estruturas do tipo pinch-and-swell, no Domínio estrutural 3 onde a litologia predominante pertence ao Complexo Gnáissico/ Migmatítico. 


\section{6-Domínio Estrutural 5: Sistema de Cavalgamento São Sebastião}

O Sistema de Cavalgamento São Sebastião ocorre no extremo sudeste da área em estudo. Duas zonas principais de cavalgamento bordejam o Granito Guaecá (figura 5.1).

A primeira zona de cavalgamento ocorre próximo à encosta ingrime que forma a Serra do Mar ao longo do contato entre o Complexo Gnáissico/ Migmatítico e o Granito Guaecá na praia de Guaecá. Localmente, a zona de cavalgamento corresponde a intercalações centimétricas a métricas destas duas unidades litológicas. A foliação apresenta um fabric proto-milonítico com mergulhos suaves entre 20-30 graus para NW. Lineações de estiramento e mineral caem obliquamente para o norte indicando que o movimento ao longo desta zona não foi de cavalgamento puro mas também contou com um componente horizontal (figura 5.1).

Indicadores cinemáticos como shear bands (figura 5.12 D), e porfiroclastos do tipo $\sigma$ e $\delta$ são observados localmente e indicam transporte tectônico para o SSE (figura $5.12 \mathrm{C}$ ). A orientação dos eixos das dobras isoclinais e de dobras em bainha indicam direção de movimento similar a orientação indicada pelos porfiroclastos.

Dobras intrafoliais e rods de quartzo são feições estruturais comuns na zona de cavalgamento (figura 5.14).

Em geral estas dobras intrafoliais aparecem dobrando o bandamento composicional e tem como foliação plano axial a foliação regional. Apresentam muitas vezes espessamento de charneira e flancos rompidos. São comuns também no Domínio 3 onde também ocorrem dobras D2 que aparecem dobrando a foliação regional e que localmente apresentam foliação plano axial, estas dobras (D2) são porém dobras abertas, e sua ocorrência é bem restrita, geralmente associada a planos de cisalhamento que ocorrem no Complexo Gnáissico/Migmatítico. 

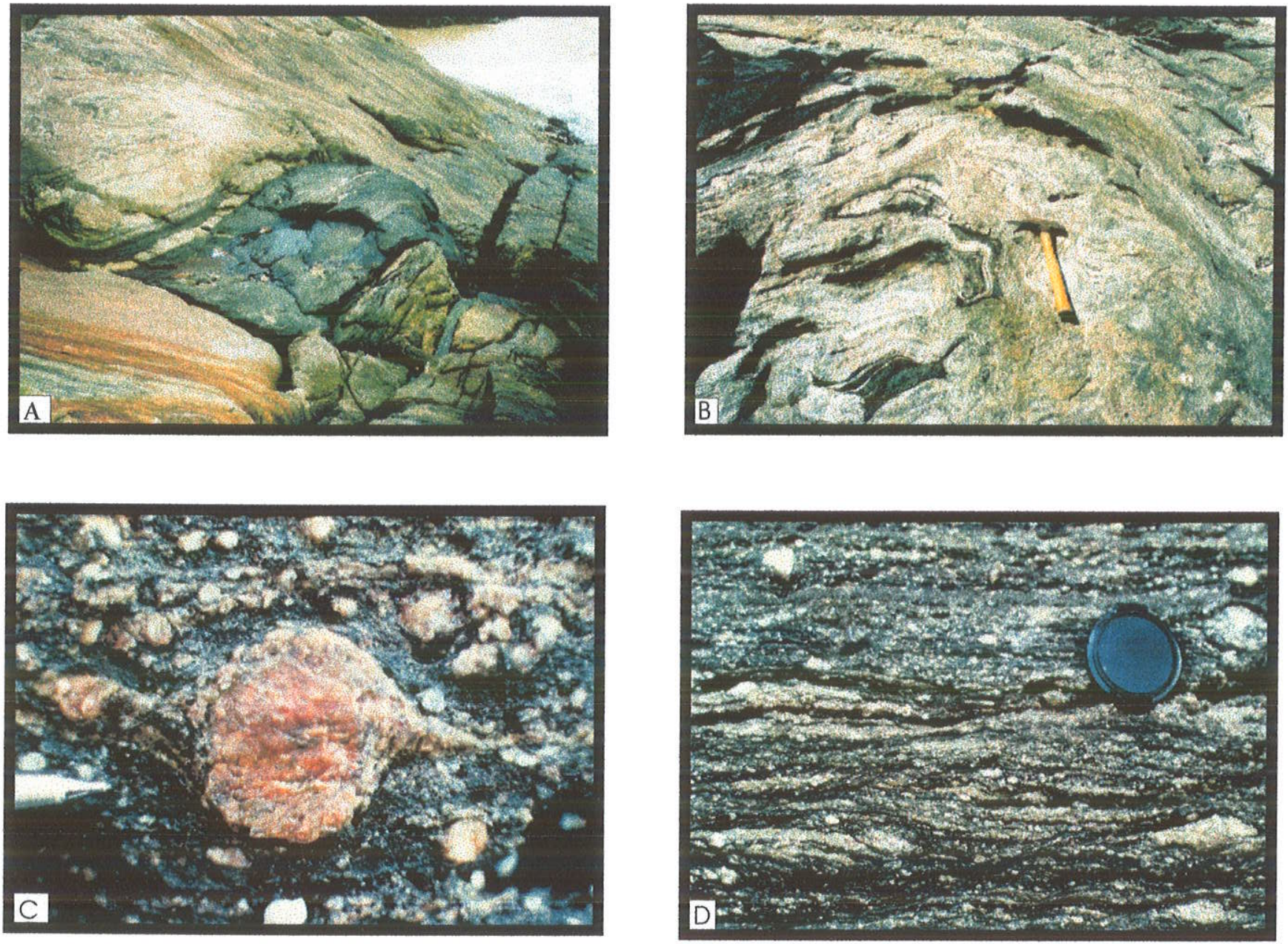

Figura 5.13

A: Enclave de anfibolito deformado. Próximo ao Sistema de Cavalgamento São Sebastião

B: Foliação dobrada em enclave deformado - Praia da Paúba.

C: Porfiroclasto indicando movimentação para SE - Sistema de Cavalgamentos São Sebastião.

D: Shear Band Cleavage - Sistema de Cavalgamento São Sebastião. Note o ângulo entre C' e foliação de S. 
A segunda zona de cavalgamento identificada no Sistema de Cavalgamentos São Sebastião ocorre ao longo do contato entre o Granito de Guaecá e novamente um nivel de ocorrência do Complexo Gnáissico / Migmatítico, disposto tectonicamente em um pacote estrutural inferior.

Trata-se de uma zona extensa (de alguns quilometros) com limites não bem definidos e onde o fabric milonítico ocorre afetando todas as litologias.

A foliação milonítica nesta zona é mais intensa do que na zona de cavalgamento anteriormente mencionada. Aqui a foliação tem mergulho subhorizontal com ângulos que variam de 10 a 30 graus.

Microestruturalmente os milonitos contém ribbons de quartzo estirados com extinção de ondulante, e alguns porfiroclastos de plagioclasio (tipo $\phi$ ) arredondado. A foliação é bem desenvolvida devido à ocorrência de uma quantia considerável de biotita (ao redor de $20 \%$ ). Alguns zircões arredondados e também muscovita ocorrem em quantidade inferior a $1 \%$.

Lineações mineral e de estiramento bem desenvolvidas apresentam caimento para N. Outra feição linear forte que ocorre na lapa são dobras em bainha. Elas ocorrem em grande quantidade e apresentam eixos com caimento suave com mesma atitude das lineações mineral e de estiramento.

Dobras em bainha são dobras fortemente não-cilíndricas na forma de uma envoltura, normalmente com eixo paralelo à lineação de estiramento. Elas são comuns em zonas cisalhamento, especialmente em milonitos.

São uma categoria especial de estruturas tubulares e quando em seções longitudinais assemelham-se a um tubo, enquanto em outras seções elas aparecem ter forma elíptica (Passchier \& Trouw, 1996).

São geradas devido a um efeito de distorção local no campo de fluxo durante gênese do milonito (Cobbold \& Quinquis, 1980; Lacasin \& Mattauer, 1985 apud 
Passchier \& Trouw, op.cit.) e quando não são tubulares mas cilíndricas, com o eixo de dobra paralelo a lineação de estiramento, são conhecidas como dobras oblíquas.

Outra característica desta zona é o forte desenvolvimento local de estruturas lineares. Ao longo da costa, no Costão do Navio, as estruturas lineares são tão bem desenvolvidas que of fabric pode ser interpretado como um L - tectonito.

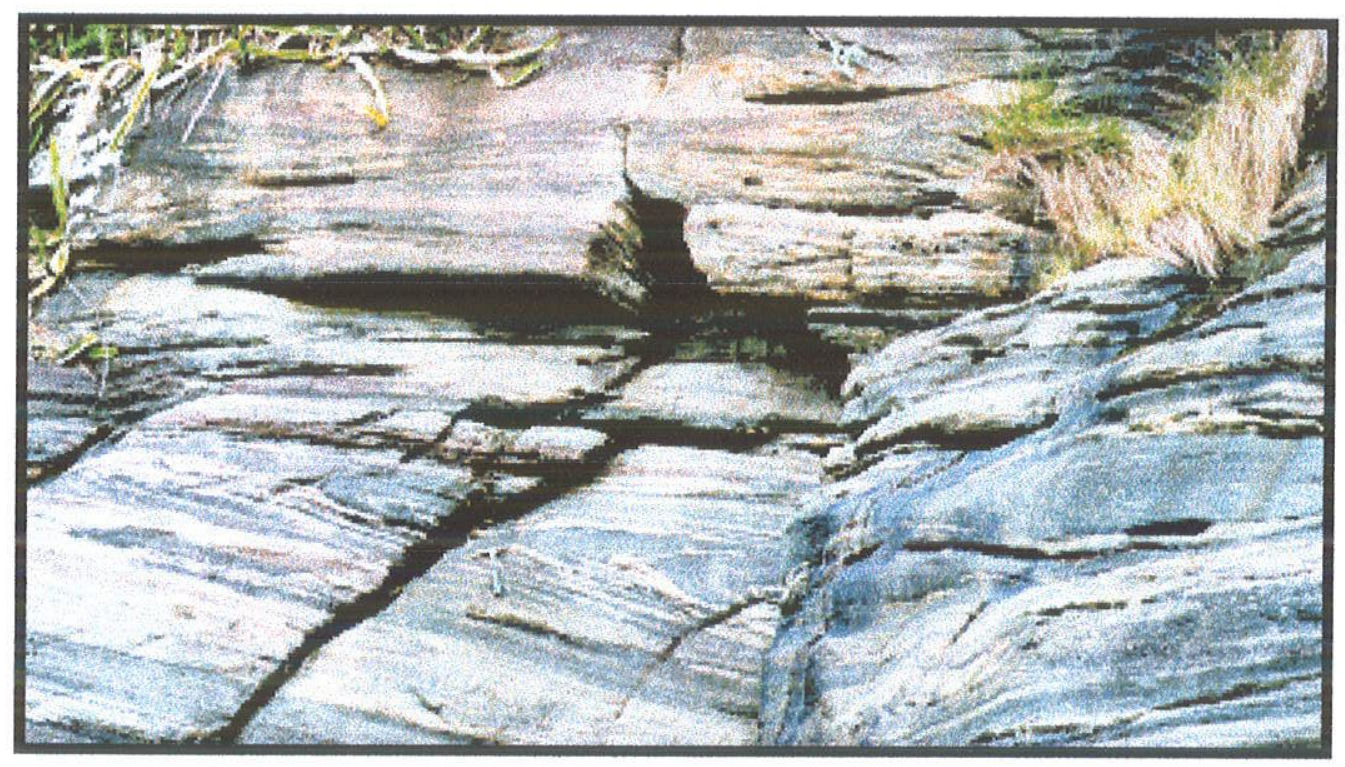

Figura 5.14 - Dobras intrafoliais. Ocorrem em toda a área de estudo e apresentam-se dobrando o bandamento composicional.

No caso do primeiro cavalgamento do Sistema de Cavalgamento São Sebastião (SCSS), o que observamos nos estereogramas (figura 5.15) é que o mergulho da foliação é suave (cerca de $30^{\circ}$ a $20^{\circ}$ ) para NW e as lineações de estiramento tem caracter predominantemente obliquo para NNE.

No segundo cavalgamento o que observamos é que a foliação continua mergulhando para NNW porém em ângulos mais baixos $\left(20^{\circ} \mathrm{a} 15^{\circ}\right)$. 
Dados: 60

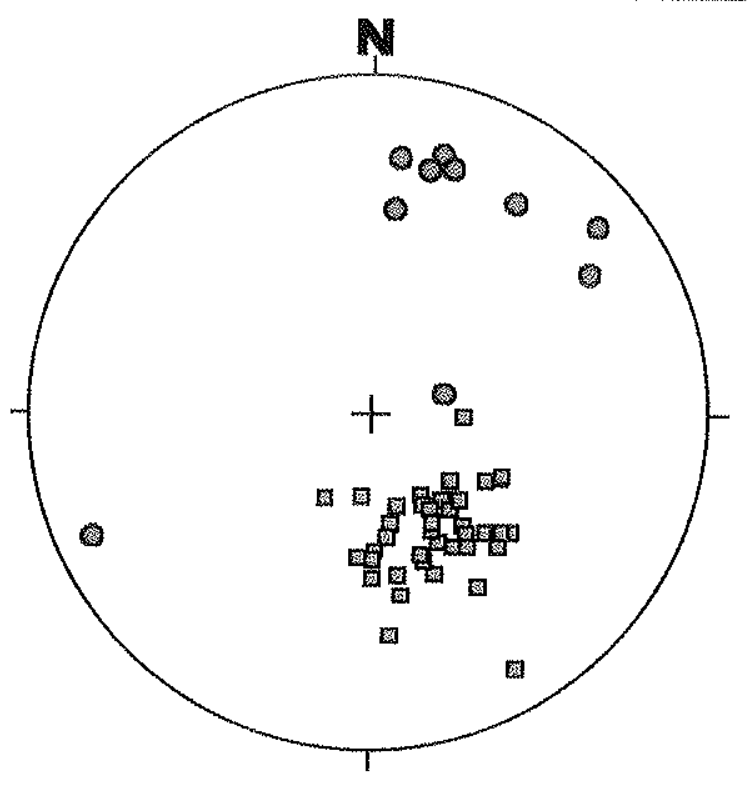

Figura 5.15 - O estereograma apresenta a projeção polar da foliação (em quadrados cinzas) e lineação (círculo vermelho) do primeiro cavalgamento do Sistema de Cavalgamentos São Sebastião, na praia de Guaecá e no Pontal da Partida na cidade de São Sebastião.

A lineação neste segundo cavalgamento embora mantenha-se obliqua em relação à foliação apresenta atitude mais concordante com o movimento de empurrão, tendo caimento para Norte (figura 5.16).

Neste segundo cavalgamento uma estrutura observada são dobras em bainha cujas orientação de seus eixos coincide com a orientação das lineações de estiramento (figura 5.17).

Estas dobras ocorrem na lapa do cavalgamento e tem sua ocorrência limitada à área da ponta do Guaecá onde aparentemente aflora a porção mais deformada deste cavalgamento. Como este ocorre no contato entre litologias do Complexo Gnáissico/ Migmatítico (base) e o leucogranito Guaecá, muitas vezes são observadas pequenas lascas do leucogranito no biotita gnaisse e vice-versa, próximo ao contato.

Se o movimento ao longo do Sistema de Cavalgamentos São Sebastião foi sincrônico ao movimento ao longo da Zona de Cisalhamento Camburu uma 
possivel interpretação é a existência de uma estrutura em flor positiva na região (Campanha \& Ens, 1996; Campanha, Ens \& Ponçano, 1994).

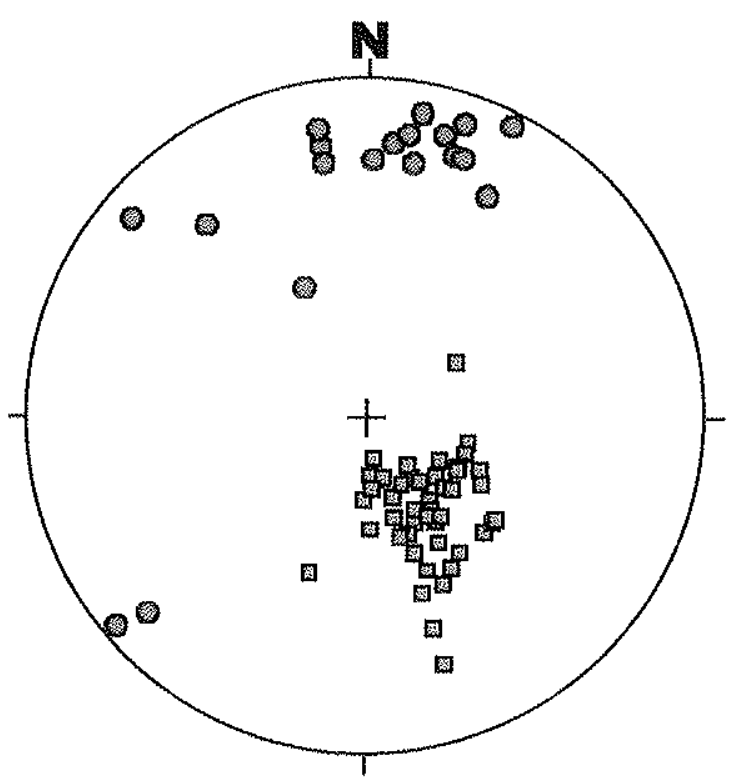

Dados: 87

Tigura 5.16 - O estereogama apresenta a projeção polar da foliação (em quadrados cinzas) e lineação (círculo vernelho) do segundo cavalgamento do Sistema de Cavalgamentos São Sebastião, na ponta do Guaecá e praia Grande.

Dados: 27

Linhas de contorno: 5

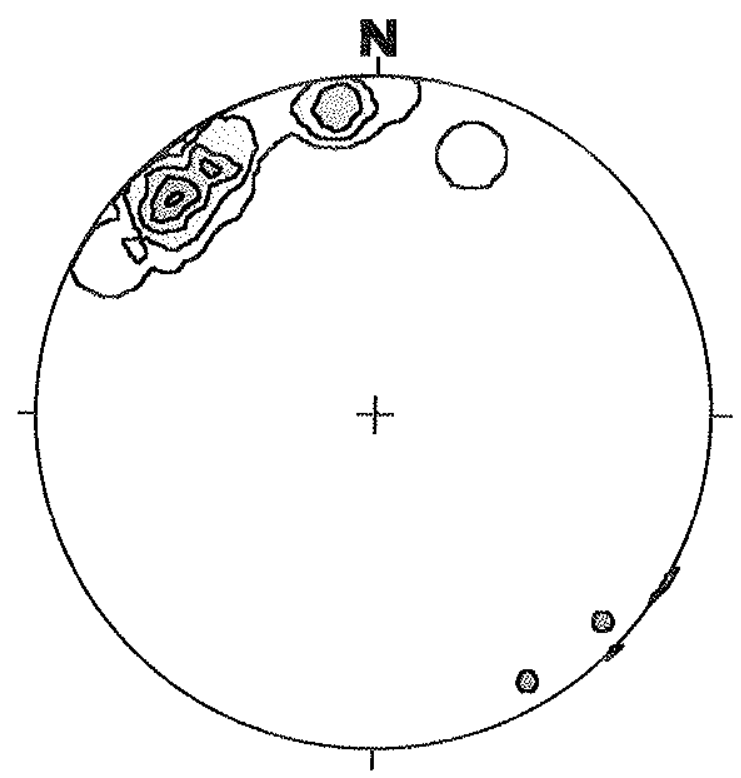

Figura 5.17-Estereograma com a projeção dos eixos das dobras em bainha, da ponta do Guaecá associadas ao primeiro cavalgamento do Sistema de Cavalgamentos São Sebastião. 
Outra possibilidade é que o processo de deformação iniciou com o desenvolvimento do Sistema de Cavalgamentos São Sebastião e terminou em movimento transcorrente na Zona de Cisalhamento Camburu e Bairro Bairro do Alto. Ambos os casos apoiam um modelo transpressivo responsável pela configuração estrutural da área.

\section{7- Análise da Macroestrutura}

Analisando o comportamento das foliações e lineações da área como um todo podemos observar que a foliação encontra-se disposta ao longo de um grande círculo (figura $5.18 \mathrm{~A}$ ) indicando mudança no rumo do mergulho de SE (Granito Pico do Papagaio) para NW ( a partir do Augen Gnaisse Juqueí para leste, a leste da falha de Camburu). As lineações também apresentam mudanças no sentido do seu caimento e passam ao longo da área de ESSE, próximo a Zona de Cisalhamento do Bairro do Alto, para SSE entre as Zonas Bairro do Alto e Camburu e depois apresenta caimento para ENE (WSW) na Zona de Cisalhamento Camburu e passa a NNE e N próxima ao Sistema de Cavalgamento São Sebastião (figura 5.18 B).

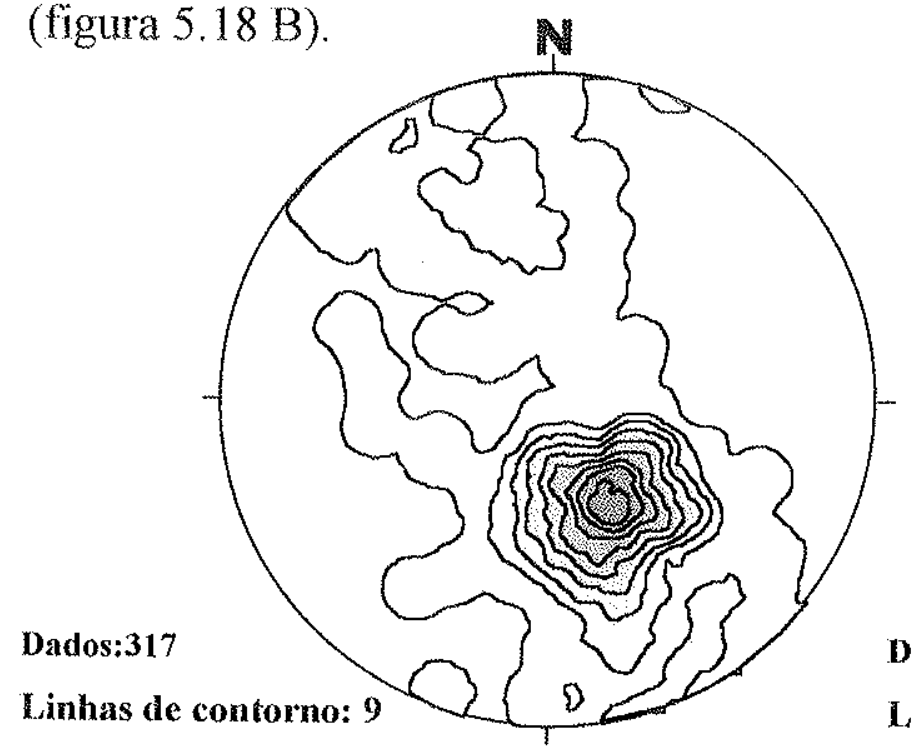

$0.32 \%$ cada
A

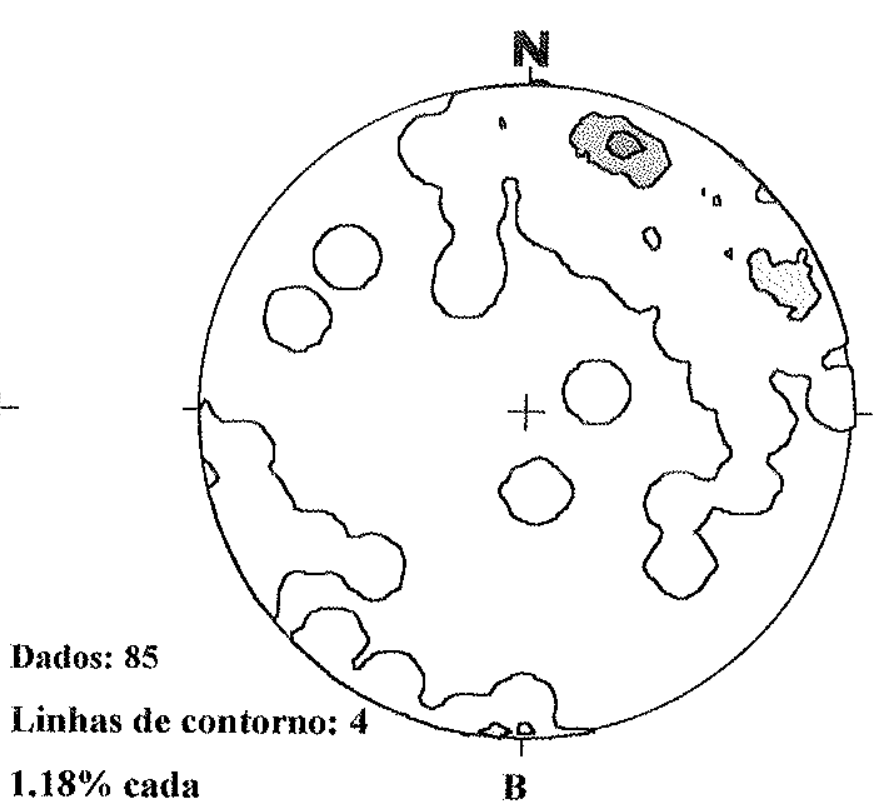

$1.18 \%$ cada

Figura 5.18 - Em A temos dados da foliação da área total de estudo, em B temos dados da lineaçâo da área total de estudos. 
Este padrão de comportamento tanto da foliação como da lineação, tratandom se de estruturas desenvolvidas durante um mesmo evento tectônico, sugere que esta geometria desenvolveu-se em um regime transpressivo. Sanderson \& Marchini (1984) apresentam um padrão similar para uma zona transpressiva.

Em termos gerais podemos dizer que:

1) Entre as zonas de cisalhamento do Bairro do Alto e Camburu foliações miloníticas com mergulho para SE contém lineações com caimento suave para SSE indicando cavalgamento. Neste caso o cavalgamento corresponde a uma zona discreta e indica movimento para NW.

2) No Sistema de Cavalgamento São Sebastião o caráter oblíquo das feições lineares é evidente. Esta característica sustenta a idéia de um movimento oblíquo que combina empurrões com movimento transcorrente dextral. Um fato que sugere simultaneidade na geração dos cavalgamentos e da Zona de Cisalhamento Camburu é a ausência de relaçôes de superposição. Porém além das lineações obliquas ocorre também no domínio dos cavalgamentos algumas lineaçǒes concordantes com movimentos direcionais e há a ocorrência local de lineações dip-slip ao longo da Zona de Cisalhamento Camburu. Estes dados podem sugerir evidências de partição do strain em um regime de tranpressivo. Por outro lado isto pode significar a ocorrência de zonas onde as lineações de cavalgamento encontram-se preservadas do movimento transcorrente, desta forma as zonas cisalhamento transcorrentes poderiam ter se instalado tardiamente aos cavalgamentos, também como resposta a partição do strain.

3) $\mathrm{Na}$ área de estudo várias indicações apontam para partição do strain com forte componente de cisalhamento coaxial, em escalas regionais e locais. As lineações de estiramento "dip slip" encontradas na ZCC podem refletir a predominância local de cisalhamento coaxial como resultado da partição do strain. 
Capítulo 6 


\section{Capítulo 6: Discussão}

\section{1-Introducão}

Zonas ou cinturões de cisalhamento foram definidos originalmente como zonas tabulares de deformação intensa. Ramsay \& Graham (1970) estabeleceram um modelo cinemático inicial e aceito em linhas gerais até hoje. Postularam como campos de deformação possíveis o cisalhamento heterogêneo, a variação de volume heterogênea, a deformação homogênea sobre uma zona de cisalhamento e blocos encaixantes ou a combinação entre estes três campos.

Outra corrente de pesquisadores adotou um modelo associado ao conceito de transpressão onde assume-se a ocorrência de cisalhamento puro perpendicular às paredes da zona de cisalhamento, e de cisalhamento simples paralelo a elas.

Regimes transpressionais promovem encurtamento e espessamento da crosta, com transferência de material da crosta inferior para a crosta media e superior. Este processo é responsável por cavalgamentos e dobramentos, geração de estruturas em flor positiva e, com a mobilização de fluidos, podem ocorrer fusões parciais (Ebert, 1995).

O cinturão Ribeira tem sido interpretado como um cinturão transpressivo (Ebert et al., 1993; Endo \& Machado, 1993; Fragoso Cesar, 1993; Wiedemann et al., 1996; Machado, 1997; Fassbinder, 1996) e a ocorrência de duplexes, sistemas de cavalgamentos, zonas de cisalhamento transcorrentes e, estruturas em flor tem sido amplamente reportadas (Ebert et al., 1993; Campanha, Ens \& Ponçano, 1994; Heilbron et al., 1996; Machado \& Endo, 1993). 
Para a área de estudo trabalhos recentes sugerem a ocorrência de uma estrutura em flor positiva (Campanha, Ens \& Ponçano, 1994; Campanha \& Ens, 1996) mas a geometria desta estrutura não havia sido estudada em detalhe.

O escopo deste capítulo é analisar os dados relacionados à geologia regional, litologias, domínios estruturais e interpretação de imagem, apresentados nos capítulos anteriores afim de contribuir à caracterização da geometria da estrutura local e entender os processos envolvidos durante sua formação.

\section{2- Transpressão}

Nos últimos vinte anos a interpretação de regimes de convergência obliqua de placas tem levado a modelos de geração de estruturas reunidos, em geral, sob a denominação de transpressão.

Vários significados tem sido atribuídos ao termo Transpressão. Segundo Robin \& Cruden (1994), pode-se dizer que existem dois significados básicos para o termo: um mais geral, que poderia ser chamado de "tectônico", no qual a transpressão referem. se a processos e estruturas resultantes da convergência oblíqua de duas placas ou terrenos. Esta convergência poderia, por exemplo, ser acomodada por partição da deformação, em transcorrências paralelas à faixa e empurrão, a ela perpendicular. Outro sentido, mais restrito, que poderia ser chamado de "estrutural" refere-se a modelagem matemática de uma zona de deformação tabular, em geral tomada como vertical, submetida simultaneamente a cisalhamento puro perpendicular a suas paredes, e cisalhamento simples a elas paralelo. 
Harland (1971) foi um dos pioneiros a discutir a deformação atuante em zonas de convergência oblíqua de placas. Ele definiu o que convencionou-se chamar de Transpressão Simples, o resultado de uma colisão de placas não ortogonal onde duas placas convergem obliquamente em na direção de encurtamento regional. Harland (op.cit.) também aponta para o que se chama Sheared Transpression, onde a transpressão é discutida em um número de diferentes possibilidades de caminhos da deformação; o primeiro corresponderia a uma compressão ortogonal seguida por transcorrência, o segundo implicaria em um movimento obliquo seguido por transcorrência e o terceiro possibilitaria o sincronismo entre transcorrência com a compressão, normal ou obliqua.

Sanderson \& Marchini (1984) modelaram matematicamente a transpressão e consideraram transpressão como um regime envolvendo a combinação de cisalhamento puro e simples sem variação do volume. Neste caso só haveria a predominância de um ou outro mecanismo em casos especiais. Segundo os autores transpressão seria caracterizada por elipsoides oblatos $(k<1)$, foliações verticais e lineações tanto verticais como horizontais (figura 6.1). Esta mesma abordagem, com algumas variações, foi seguida por diversos outros autores como Fossen \& Tikoff (1993), Tikoff \& Fossen (1994).

Mas a modelagem apresentada por Sanderson \& Marchini (op.cit.) apresenta incompatibilidades mecânicas, uma vez que prevê que as paredes da zona de transpressão não apresentam fricção no sentido vertical mas resistem ao deslizamento no sentido horizontal. 


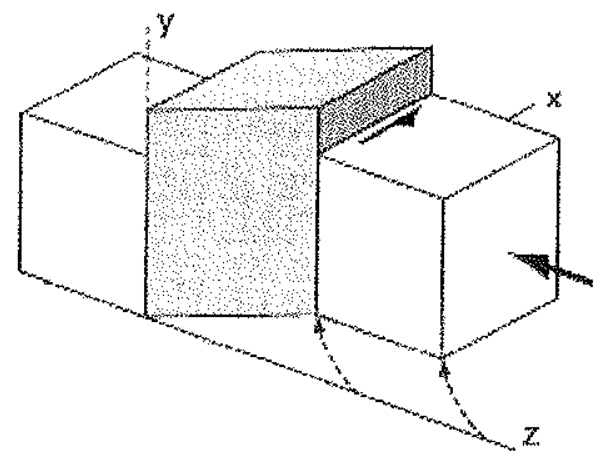

Figura 6.1 - Esta figura mostra a geometria de uma zona de transpressão segundo Sanderson \& Marchini (1984), que neste caso mostra encurtamento paralelo ao eixo Z e cisalhamento paralelo ao eixo X.

Robin e Cruden (1994) apresentaram outra modelagem matemática onde o problema de compatibilidade mecânica é solucionado através de uma distribuição heterogênea da deformação ao longo da zona. Nesta modelagem tanto a foliação como a lineação podem variar em orientação (figura 6.2).

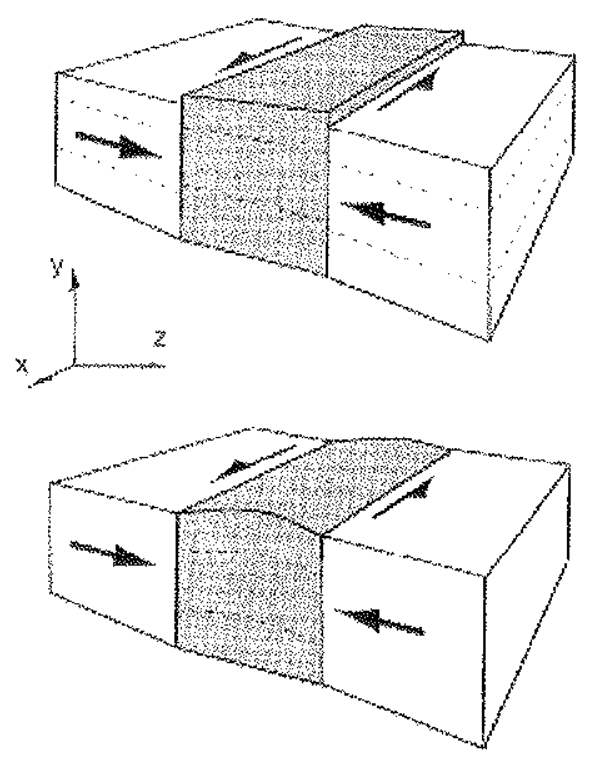

Figura 6.2 - Nesta figura observamos inicialmente (parte superior) a modelagem de Sanderson \& Marchini (1984) que prevê volume constante e a deformação distribuida de forma homogênea ao longo da zona, abaixo encontra-se a modelagem de Robin e Cruden (1994) onde a deformação é heterogênea. 
A modelagem de Sanderson \& Marchini (1984) apresenta o que convencionou-se chamar de Tramspressão Homogênea, onde o strain é distribuido uniformemente ao longo da zona. A modelagem de Robin e Cruden (1994) por sua vez apresenta o que convencionou-se chamar Transpressão Heterogênea, onde, o strain varia ao longo da zona bem como a atitude da foliação e da lineação.

Outros autores apresentam o conceito de transpressão associado à partição regional da deformação e à colisão obliqua. Trata-se de modelagens físicas, ou numéricas como em Tikoff \& Teyssier (1994), Richard \& Cobbold (1990), Merle \& Gaspais (1997).

Nestes outros modelos ao invés de se ter uma deformação com cisalhamento simples e puro simultâneos ou em empurrões com movimentos oblíquos o que se tem é uma partição física da deformação em empurrões frontais ou oblíquos, e transcorrência paralela à zona de colisão.

Segundo Jones \& Tanner (1995) a partição da deformação pode ocorrer em função de heterogeneidades prévias (como contatos litológicos, heterogeneidades reológicas e zonas de cisalhamento) nos orógenos.

Há também trabalhos que consideram que o fator controlador da partição é o ângulo de convergência entre as placas tectônicas (Tikoff \& Greene, 1997).

\section{3 - Colocacão de Granitos em Regimes Transpressivos}

Embora não seja o enfoque principal deste trabalho, é relevante salientar a ocorrência de dois corpos graníticos na área de estudo: o Granito Pico do Papagaio 
(GPP) e o Granito Guaecá (GG), isto porque as associações magmáticas de cinturões móveis refletem as condições tectônicas em que foram desenvolvidos.

Vários estudos mostram que plútons graníticos podem ser intrudidos durante eventos contracionais (Karlstrom \& Williams, 1995; Paterson \& Fowler, 1993; Nummer, 1996), neste caso o magma é injetado devido à pressão hidrostática, ao contraste de densidade e a forças compressionais.

Pitcher (1982) estudou diferentes tipos de granitos e os associou a diferentes contextos tectônicos. Genericamente podemos dizer que Pitcher (op.cit.) identificou cinco tipos básicos de granitos: granitos tipo $\mathbf{M}$, basicamente plagiogranitos com gabro subordinado e xenólitos de rochas básicas, associados a ambientes de arcos de ilhas; granitos tipo I (Cordilheranos) predominantemente tonalitos mas abrange toda a faixa que se estende de diorito a monzogranitos, apresentam hornblenda e biotita $\mathrm{e}$ são associado a ambiente tipo margem continental ativa andina; granitos tipo I (Caledoniamos) predominantemente granodioritos e granitos com biotita, ilmenita e magnetita, associados a ambiente de soerguimento; granitos do tipo $\mathbf{S}$, geralmente leuco-monzogranitos e granitos duas micas, associados a ambientes de colisão continental; e granitos tipo A, geralmente biotita granitos e série de alcali granitos e sienitos, associados a ambientes pós-orogênicos e anorogênicos. O autor menciona a ocorrência de granitos do tipo $\mathrm{S}$ em uma associação magmática do tipo Hercínica. Esta associação foi primeiramente citada como ocorrência ao longo de uma cadeia montanhosa na Europa Ocidental, formada por uma colisão continental. Aqui o magmatismo é formado por uma associação de granitos peraluminosos com predominância de granitos do tipo $\mathrm{S}$ porém com granitos do tipo I subordinados. 
Estes dois tipos de granitos ocorrem como plútons alinhados separados por zonas de cisalhamento dúcteis.

Ainda segundo Pitcher ( $o p$. cit.) zonas de cisalhamento de alto ângulo são importantes na colocação de granitos porém cavalgamentos de baixo ângulo talvez sejam até mais importantes porque promovem o espessamento da crosta que contribui para a fusão crustal.

No caso de um regime transpressivo o componente compressivo é a "máquina" que controla a ascensão do magma ao longo de zonas de cisalhamento.

Os componentes de "achatamento" e de "cisalhamento" promovem o estiramento dos plútons, a orientação mineral e forte deformação no estado sólido.

A geometria dos plútons graníticos é funçăo das condições tectônicas da região. Plútons alongados com forma sigmoidal e com eixos maiores paralelos ao plano $\mathrm{XY}$ regional são caracteristicamente sintectônicos (Nummer, op.cit.).

Molyneux \& Ebert (1997) estudaram alguns corpos graníticos ao longo do Cinturão Ribeira. Para eles os plútons associados a zonas de cisalhamento transcorrentes subverticais apresentam foliações em estado sólido e magmático paralelas as paredes das zonas. Composicionalmente homogêneos, eles foram colocados predominantemente através de sheeting durante uma orogenia transpressiva. De acordo com estes autores porém, estes plútons não preservam qualquer característica que indique compressão e sugerem uma extensão local para sua colocação. 
Heterogeneidade composicional, alto strain magmático e em estado sólido podem indicar forte componente de compressão na colocação de granitos (Molyneaux \& Ebert, 1997).

Na área de estudo, o Granito Pico do Papagaio é um plúton bordejado pelas Zonas de Cisalhamento Bairro do Alto e Camburu. É um corpo bem foliado, com variação forte na intensidade de deformação. A foliação dentro do plúton mostra a mesma orientação das zonas de cisalhamento. A geometria geral do plúton não é bem definida na área de estudo em função de sua grande extensão.

O Granito Guaecá é um granodiorito bem foliado. A foliação regional continua dentro do plúton que é bordejado em ambos os lados pelos cavalgamentos principais que pertencem ao Sistema de Cavalgamentos São Sebastião (SCSS). Este corpo apresenta uma forma alongada com os eixos maiores paralelos à foliação regional (anexo 1). É composicionalmente heterogêneo com duas fácies distintas; uma fácies leucocrática e outra fácies rica em biotita.

Estas observações sugerem que o granito Guaecá seja sintectônico com presença de forte componente compressional durante ou nos estágios finais de sua colocação. $O$ componente compressional também é sugerido pela ocorrência de mirmequitas no feldspato potássico perpendiculares ao plano da foliação.

Outra possibilidade é que o Granito Guaecá tenha sido gerado devido a fusão parcial associada ao processo de migmatização.

A conexão entre granitos e migmatitos é aceita por vários autores e explicada através da diferença na taxa de fusão. Taxas de fusão elevadas favorecem o 
mecanismo de segregação e isso é favorecido pela presença de minerais hidratados ou de uma fase volátil rica em água (Machado, 1997).

$\mathrm{Na}$ de área de estudo sillimanita ocorre associada a biotita, no Complexo Gnáissico / Migmatítico. Neste caso a sillimanita pode representar uma reação progressiva geradora de água (Capítulo 4). A sillimanita pode coincidir com a formação dos migmatitos porque a água contribui para reduzir a temperatura de fusão (Shelley, 1993).

$\mathrm{Na}$ área de estudo os migmatitos apresentam claramente duas estruturas principais: a estromatítica e a flebítica/schlieren. Esta variação poderia ser associada a diferenças em gradientes de deformação (strain). A estrutura estromatítica ocorre próxima ao Sistema de Cavalgamentos São Sebastião, onde maior deformação (mais alto strain) é esperado, ela poderia ser derivada de níveis de restitos que sofreram achatamento e estiramento. As estruturas schlieren e flebítica ocorrem na área entre a Zona de Cisalhamento Camburu e o sistema cavalgamentos, onde observa-se deformação menor.

No caso do Granito Pico do Papagaio as evidências de sua colocação sintectônica não estão claras. A única relação clara é que não se trata de um plúton pós - tectônico, uma vez que é afetado pelas Zonas de Cisalhamento Bairro do Alto e Camburu.

Em termos de composição, estes plútons têm assembléias minerais diferentes. Enquanto o Granito Pico do Papagaio contém biotita, quartzo, microclina e hornblenda, o Granito Guecá apresenta uma assembléia que inclui biotita, granada, muscovita, k-feldspato (em maior proporção que plagioclásio), quartzo e localmente sillimanita. Também foram encontrados zircões arredondados em seções delgadas do Granito Guaecá. Estas assembléias minerais sugerem que os granitos Guaecá e Pico do 
Papagaio têm origem diferentes. O granito Pico do Papagaio apresenta mais afinidade do tipo I enquanto o Granito Guaecá é interpretado como tipo S.

A diferenciação entre os granitos tipo S e I foi objeto de vastos estudos (Chappell \& White, 1974, 1984, 1992, Hine et al., 1978, Pitcher, 1978, 1982, 1987 apud Nummer, 1996). As diferenças mais significativas são relacionadas a mineralogia, petrografia, geoquímica e isótopos (Machado, 1996).

Granitos do tipo $S$ originam-se a partir da fusão de rochas supracrustais ou de metassedimentares. Composicionalmente eles têm biotita marrom-avermelhada, nenhuma hornblenda, muscovita, granada e ilmenita em vez de magnetita, sillimanita podem estar presente (caráter peraluminoso). Granitos do tipo $\mathrm{S}$ às vezes apresentam restitos, ou seja, material que representa relíquias refratárias de sedimentos parcialmente fundidos. Zircões arredondados são interpretados como possíveis relíquias sedimentares, embora o arredondamento possa também resultar de solução em magma (Machado, 1996). No caso do Granito Guaecá interpretamos que concentrações de biotita possam corresponder a estes relictos.

Campos Neto \& Figueiredo (1995) mencionam a ocorrência de cordierita sillimanita - granada - biotita granitos associados ao Cinturão Ribeira. Eles são considerados mais jovem que $550 \mathrm{Ma}$ (método U-Pb) com anomalias negativas de Eu e fracionamento moderado de LREE. Eles foram interpretados como granitos tipo $\mathrm{S}$ resultantes da fusão de uma sequência supracrustal durante a orogenia brasiliana.

Granitos do tipo I oriundos da fusão de rochas ígneas, normalmente apresentam como mineralogia hornblenda, biotita verde e marrom e material xenolítico ígneo. De acordo Campos Neto \& Figueiredo (1995) o maciço alongado de hornblenda-biotita monzogranito porfirítico encontrado nas proximidades da cidade de Ubatuba (norte da 
área de estudo) apresenta comportamento de Sr típico compatível com origem crustal $\left(\mathrm{r}_{0}=0.710-0.713\right)$, este comportamento pode corresponder a fusão parcial de uma crosta granulítica que pode estar associado a séries sin a tarde colisionais com idades entre 550-540 Ma. $\mathrm{Na}$ interpretação dos autores o Granito Pico do Papagaio foi colocado durante este evento.

De acordo com Didier et al. (apud Machado, 1996) granitos do tipo I só ocorrem como intrusões enquanto granitos do tipo $\mathrm{S}$ podem ser gerados como corpos autóctones durante o processo de migmatização. No caso do Granito Guaecá sua geometria e a associação com o sistema de cavalgamento sugerem uma intrusão na forma de sheet, sintectônica, e sua forte relação com os migmatitos pode sugerir processo anatético para sua formação. Análise geoquímica detalhada poderá ajudar a resolver esta questão.

Comparando os dados dos granitos Pico do Papagaio e Guaecá com os modelos apresentados na literatura, podemos dizer que esta associação litológica apresenta similaridade com o tipo Hercínico de Pitcher (1982), sugerindo um ambiente de colisão continental para sua formação.

\section{3-Análise das Estruturas Locais}

Normalmente espera-se que as lineações de estiramento e mineral ocorram paralelamente ou subparalelamente à direção de estiramento máximo (X). Microestruturas observadas no plano XZ são utilizadas para determinar o sentido de cisalhamento (indicadores cinemáticos). Isto é essencialmente válido para deformações planas $(\Sigma y=0)$ e especialmente no caso de cisalhamento simples. 
Estudos recentes mostram que lineações de estiramento também podem ser perpendiculares ao transporte tectônico deduzido (Sander, 1970; Hudleston et al., 1988 apud Tikoff \& Greene, 1997), entende-se neste caso a direção de transporte como a direção do componente de cisalhamento simples, ao qual é "somado" um componente de cisalhamento puro. Alguns destes estudos mostram a ocorrência de lineações de estiramento verticais em foliações com alto ângulo de mergulho (Tikoff \& Greene, op.cit). Neste caso é assumido que as lineações são perpendiculares a direção de transporte tectônico.

Sander, 1930 e 1970 (apud Tikoff \& Greene, op.cit.) descreveu lineações perpendiculares à direção de movimento como "tipo b". Tikoff e Greene (op.cit) sugeriram que elas foram geradas devido a uma combinação de cisalhamento puro e simples; descreveram a ocorrência de lineações com caimento elevado (steep plunging lineation) em foliações de alto ângulo em granitos sintectônicos do Batólito Sierra Nevada, nos E.U.A., associadas a uma zona transpressiva.

Modelamentos teóricos de strain indicam que o eixo maior do elipsóide de deformação finita pode ser vertical para algumas deformações em regimes de transpressão. Isto ocorre quando houver alto ângulo de convergência (e portanto predomínio do cisalhamento puro, com extrusão vertical) e/ou alto valor de strain (Tikoff \& Greene, 1997). A ocorrência simultânea de lineações verticais e horizontais em uma mesma zona de cisalhamento poderia ser resultado da partição da deformação, talvez devido ao contraste reológico entre litologias (Tikoff \& Greene, 1997).

A figura 6.3 descreve este modelo.

$\mathrm{Na}$ Zona de Cisalhamento Camburu indicadores cinemáticos em diferentes escalas sugerem movimento predominantemente dextral; a interpretação da imagem 
ERS-1 sugere flexão dos lineamentos ao redor da zona (vide Capítulo 3, figura 3.6) que coincide com a direção de movimento dextral. Estas evidências sugerem que o movimento dextral foi predominante.

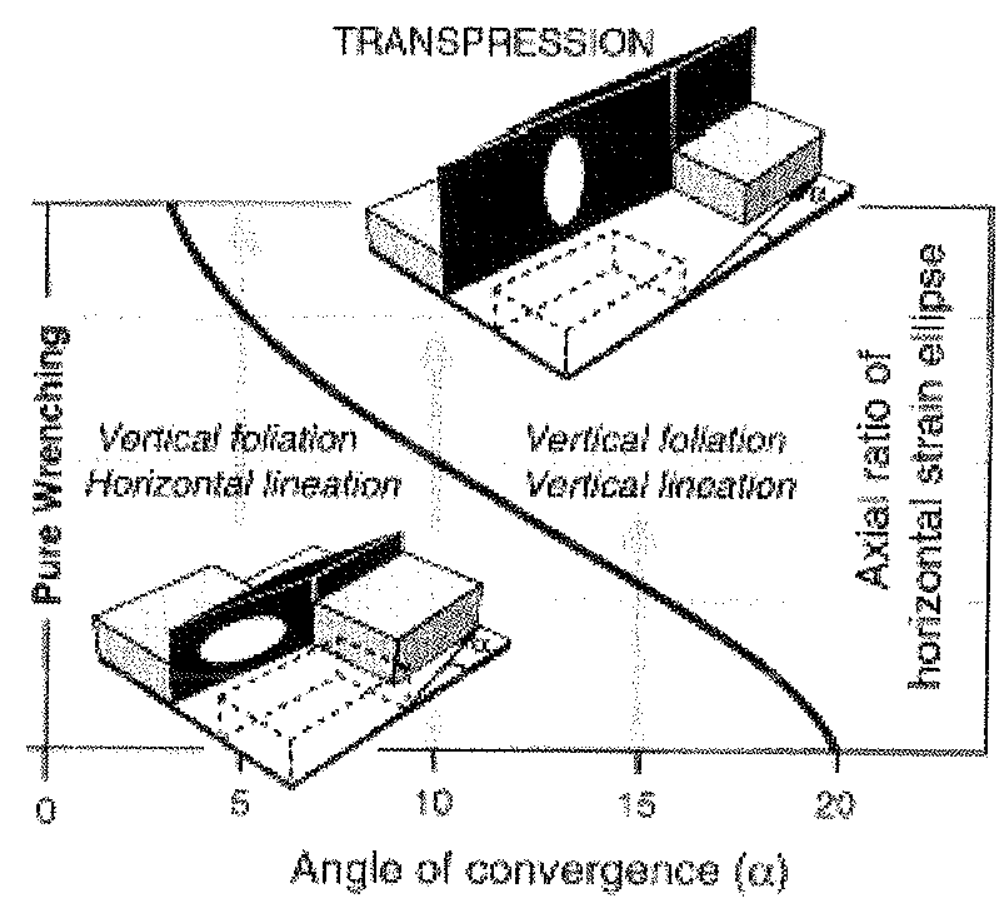

Figura 6.3 - Modelo que relaciona o ângulo de convergência com a orientação da lineação e foliação. Teyssier \& Tikoff (1999).

No entanto ocorrem também alguns indicadores cinemáticos (porfiroclastos assimétricos) que sugerem movimento sinistral (figura $5.10 \mathrm{C}$ ). Uma explicação para este fato pode ser dada pelo movimento relativo dos porfiroclastos que poderia gerar indicações de movimento contrário ao da zona de cisalhamento (Passchier \& Trouw, 1996). Cabe ressaltar também a existência de inúmeros porfiroclastos simétricos, tipo $\phi$. A ocorrência destes porfiroclastos pode ser indício que durante a deformação plástica um forte componente coaxial estava presente. Este componente coaxial que poderia ser um cisalhamento puro, com volume constante, ou achatamento uniaxial, 
com redução de volume. A ocorrência da deformação coaxial poderia ser o resultado de uma partição local da deformação.

Com relação ao comportamento geral da foliação e da lineação, o que podemos observar é uma tendência, no caso da foliação, de uma variação de atitudes que vão de SE para NW, a partir do centro da zona para as bordas, e, no caso da lineação, um movimento anti - horário, de NE para N (figura 6.4).

Além disso, os estereogramas apresentados no capítulo 5 indicam que além de uma possível partição local da deformação, indicada pela ocorrência de duas lineações (dip -slip e direcionais) no domínio de ocorrência da Zona de Cisalhamento Camburu, há também a heterogeneidade da deformação ao longo da estrutura estudada.
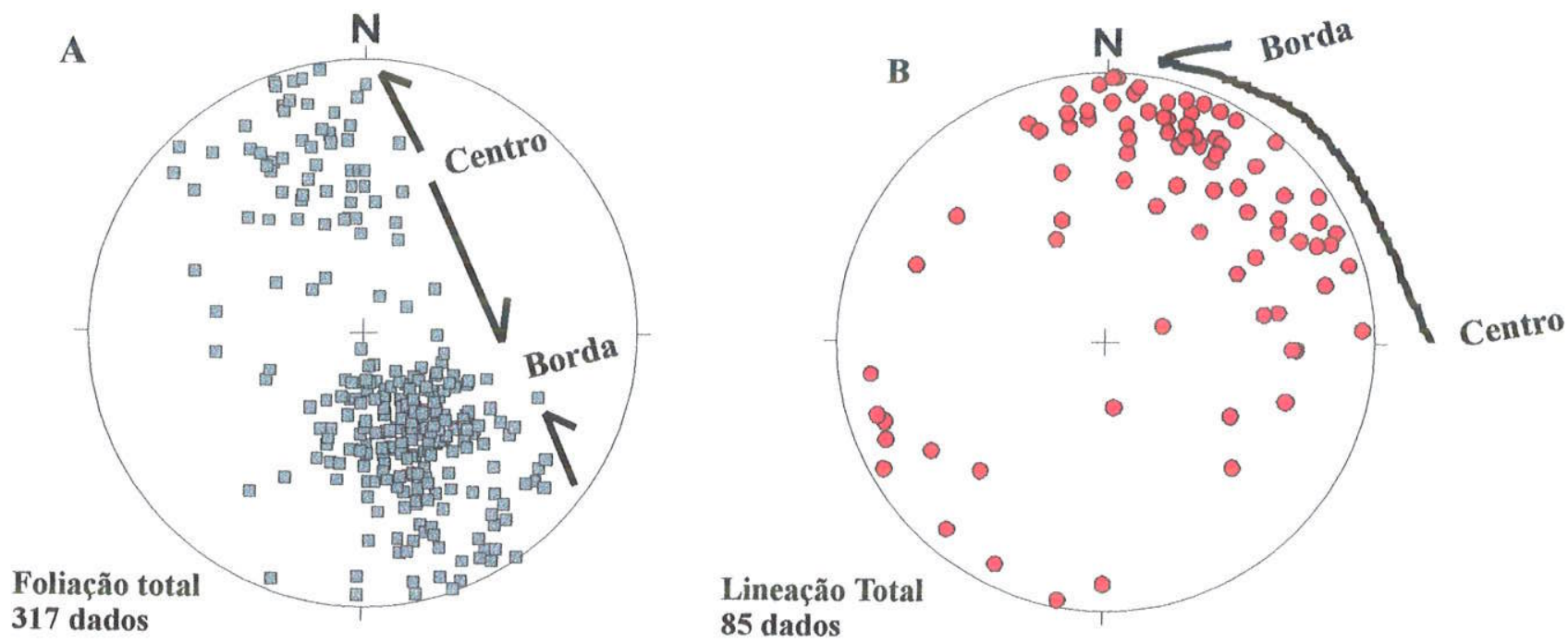

Figura 6.4 - Estereogramas indicando variação de atitudes que sofreu a foliação e a lineação ao longo da estrutura. Em A temos a projeção polar da foliação total da área de estudo, as flechas indicam o movimento relativo que as foliações apresentam do centro para a borda da estrutura. Em B temos a projeção da lineação total da área de estudo, as flechas indicam o movimento relativo que as lineações apresentam do centro para a borda da estrutura. 


\section{4-Relacões Geométricas e Modelos Propostos}

Para discutir as relações geométricas das estruturas na área de estudo é importante ter em mente o modelo estrutural regional.

Como foi mencionado anteriormente a área de estudo é parte do sistema de zonas de cisalhamento transcorrentes do cinturão Ribeira, associado à amalgamação do supercontinente Gondwana durante o ciclo Brasiliano.

Como esta orogenia afetou intensivamente a parte de sudeste do Brasil a deformação encontrada aí é relacionada a este evento.

Pode-se descrever tal orogenia brevemente como uma colisão continental. Geralmente uma colisão continental tem uma fase pré-colisional com subducção do material oceânico; uma fase colisional com espessamento da crosta e uma fase póscolisional já com a indentação das placas e deformação associada a instabilidade gravitacional (Woodcock \& Schubert, 1994).

Durante a fase colisional, com o espessamento da crosta e em um regime de transpressivo, possíveis estruturas que se desenvolvem em escala local são duplexes, estruturas em flor, cavalgamentos e zonas transcorrentes.

$\mathrm{Na}$ área de estudo a ocorrência de cavalgamentos em ambos os lados da Zona de Cisalhamento Camburu com vergência oposta, o padrão da foliação e lineação regional são fatos que sugerem a idéia de um modelo de flor positiva. Este modelo também é apoiado pela homogeneidade do metamorfismo ao longo da área. 
Os dados apresentados aqui sugerem que uma estrutura em flor positiva é um modelo satisfatório para a estrutura geral mas, diferente dos trabalhos previamente apresentados, mostra-se que a estrutura apresenta um caráter assimétrico.

Como demostrado pelas projeções estereográficas (Capítulo 5) as atitudes verticalizadas das foliações não ocorrem na zona de maior deformação da Zona de Cisalhamento Camburu; na porção de maior strain onde a foliação milonítica é mais intensa o ângulo de mergulho é moderado a alto para SE. Tal fato continua a ocorrer na unidade de Augen Gnaisses Juquei onde a mudança de direção de mergulho ocorre. Outro ponto que confirma a assimetria é a ocorrência da Zona de Cisalhamento Bairro do Alto. Considerando que a Zona de Cisalhamento Bairro do Alto desenvolveu-se como conseqüência do mesmo regime transpressional, alguma "barreira" deve ter ocorrido para finalizar os cavalgamentos nesta parte da flor em outra zona de cisalhamento transcorrente. Outra possibilidade é a de uma pequena diferença no tempo em que esta zona desenvolveu-se, possivelmente nas fases mais tardias da estrutura em flor.

A figura 6.5 ilustra o modelo proposto para o padrão estrutural geral. Os planos descrevem comportamento da foliação ao longo da estrutura; as linha contidas nestes planos representam as atitudes da lineação mineral e de estiramento. Alto strain ao longo das zonas de cisalhamento é descrito através de linhas longas. A seta pontilhada indica o movimento que é uma combinação de transcorrente dextral e cavalgamentos oblíquos.

Se nos reportarmos aos dados apresentados na literatura e previamente mencionados na seção 6.2 sobre transpressão, vemos que ao considerarmos um modelo de flor positiva, estaremos associando a um regime de transpressão onde há a partição 
da deformação. E ainda segundo alguns trabalhos, esta partição pode ter sido estimulada por anisotropias estruturais pré-existentes na área.

Para que haja a partição da deformação devemos ter definidos campos de predomínio de cisalhamento puro e campos de cisalhamento simples.

Outra hipótese é que o Sistema de Cavalgamentos São Sebastião poderia ter sido gerado durante a fase de colisão seguida por um escape tectônico de nordeste para sudoeste responsável pela formação das zonas de cisalhamento Camburu e Bairro do Alto, como também pela formação das zonas de cisalhamento transcorrentes regionais.

O modelo de tectônica de escape lateral, com indentação tectônica, foi também proposto para o Cinturão Ribeira por Vauchez, Tommasi \& Egydio Silva (1994).

Neste segundo modelo, as zonas de cisalhamento Camburu e Bairro Alto podem ser consideradas o que Woodcock \& Schubert (1994) convencionou chamar de Fallhas Tramscorrentes Indentadas (Indent-liked Strike Slip Faults), ou seja, formadas a partir de um escape lateral gerado por encurtamento crustal e normalmente associado a granitos do tipo S. A maioria destas falhas é associada a vetor de deslocamento oblíquo.

De acordo com esta concepção, os cavalgamentos formaram-se primeiro, devido a uma colisão oblíqua em um regime transpressivo e em uma mais fase tardia instalaram-se as zonas de cisalhamento transcorrentes. Neste caso nenhuma diferença metamórfica é esperada e as estruturas lineares podem ser um resultado do deslocamento oblíquo. O plano de cavalgamento discreto, com vergência oposta ao do Sistema de Cavalgamentos São Sebastião poderia ser assumido como um "backthrust". Figura 6.6 ilustra este modelo. 
A zona é caracterizada por alta deformação causando partição local com predomínio do componente de cisalhamento puro. Isto é evidenciado pela ocorrência de estruturas do tipo pinch-and-swell, e porfiroclastos do tipo $\phi$, lineações "dip-slip" ao longo de zonas de cisalhamento transcorrentes e fabric bandado altamente recristalizado.

A rotação dos elementos lineares como eixo de dobra, eixos maiores de enclaves também sugerem alto strain.

Lineações minerais e de estiramento oblíquas aos planos da foliação no Sistema de Cavalgamento São Sebastião sugerem movimento tectônico obliquo.

Temperaturas altas indicadas por fácies metamórfica em, ao menos, grau anfibolito alto, sugerem exumação lenta, típico de zonas transpressivas oblíquas (Thompson, Jesek \& Schulmann, 1997).

Diante destas evidências concluímos que o arranjo geométrico no qual encontrase dispostas as estruturas da área em estudo sugere tratar-se de um regime transpressivo heterogêneo com partição da deformação, tendo sua origem associada a uma colisão continental obliqua, com ângulo de convergência baixo, como apresentado no modelo de Transpressão Dominada por Transcorrência (Wrench Dominated Transpression), de Tikoff \& e Greene (1997). 


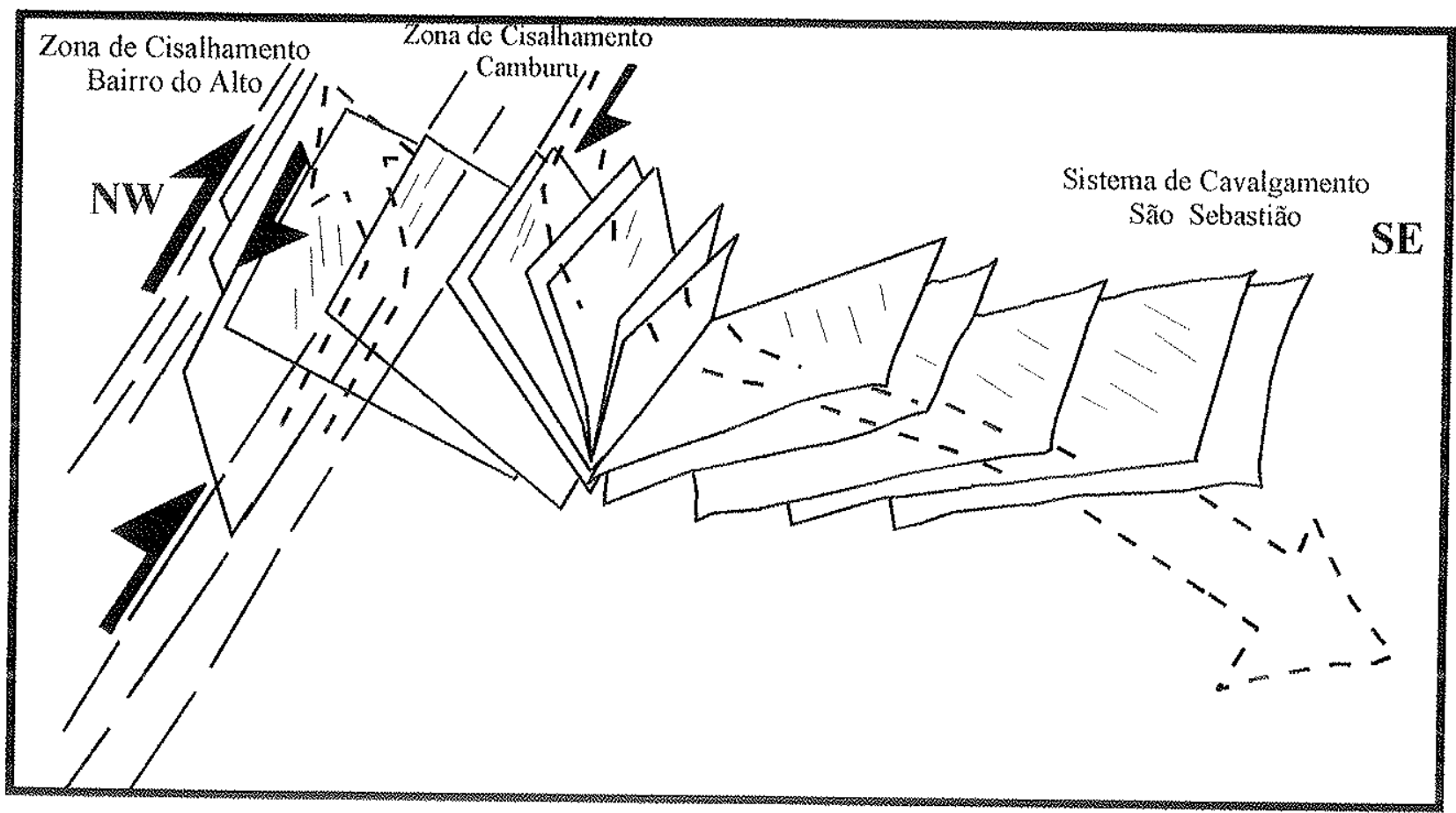

Figura 6.5 - Modelo de flor positiva proposto. Os planos descrevem o comportamento da foliação ao longo da estrutura, as linhas completas representam a atitude da lineação mineral e de estiramento. A linha pontilhada indica movimento que combina transcorrência dextral e cavalgamento obliquo. Note a assimetria da estrutura. 


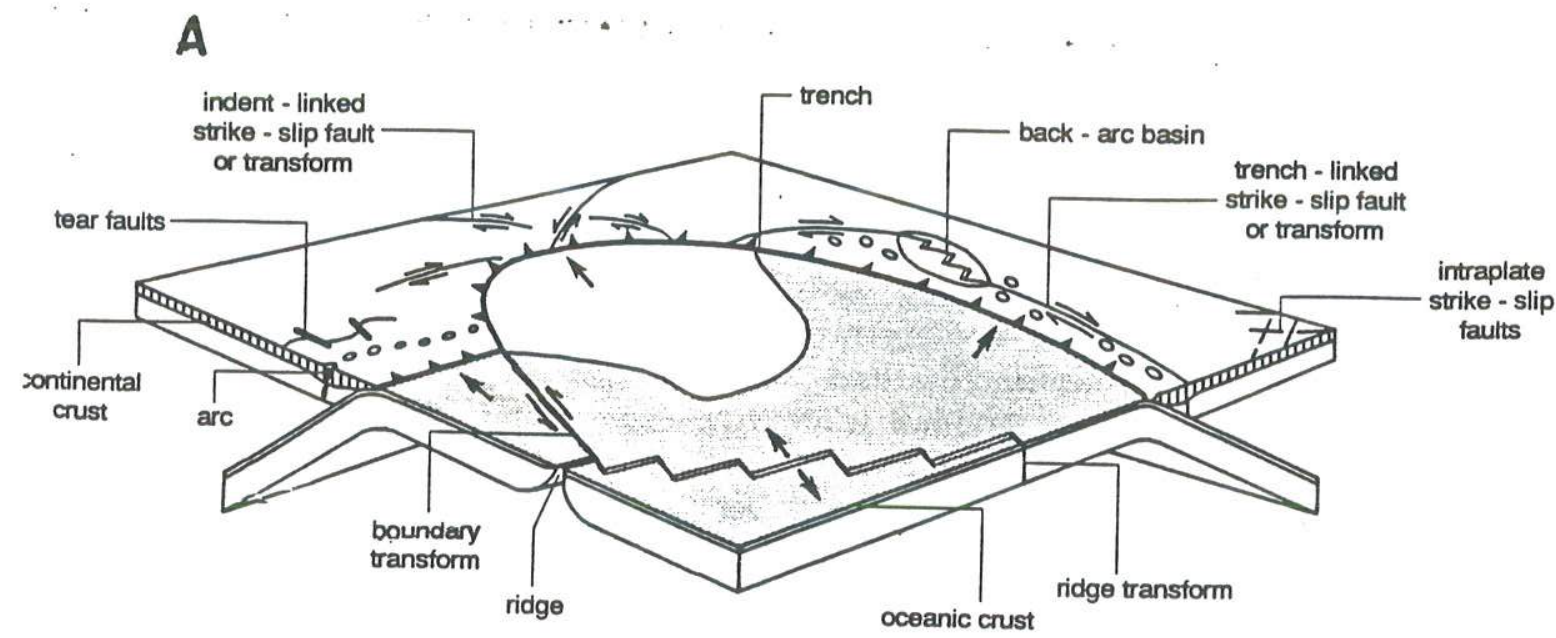

B

(a) Initial cross-section

Sedimentary cover

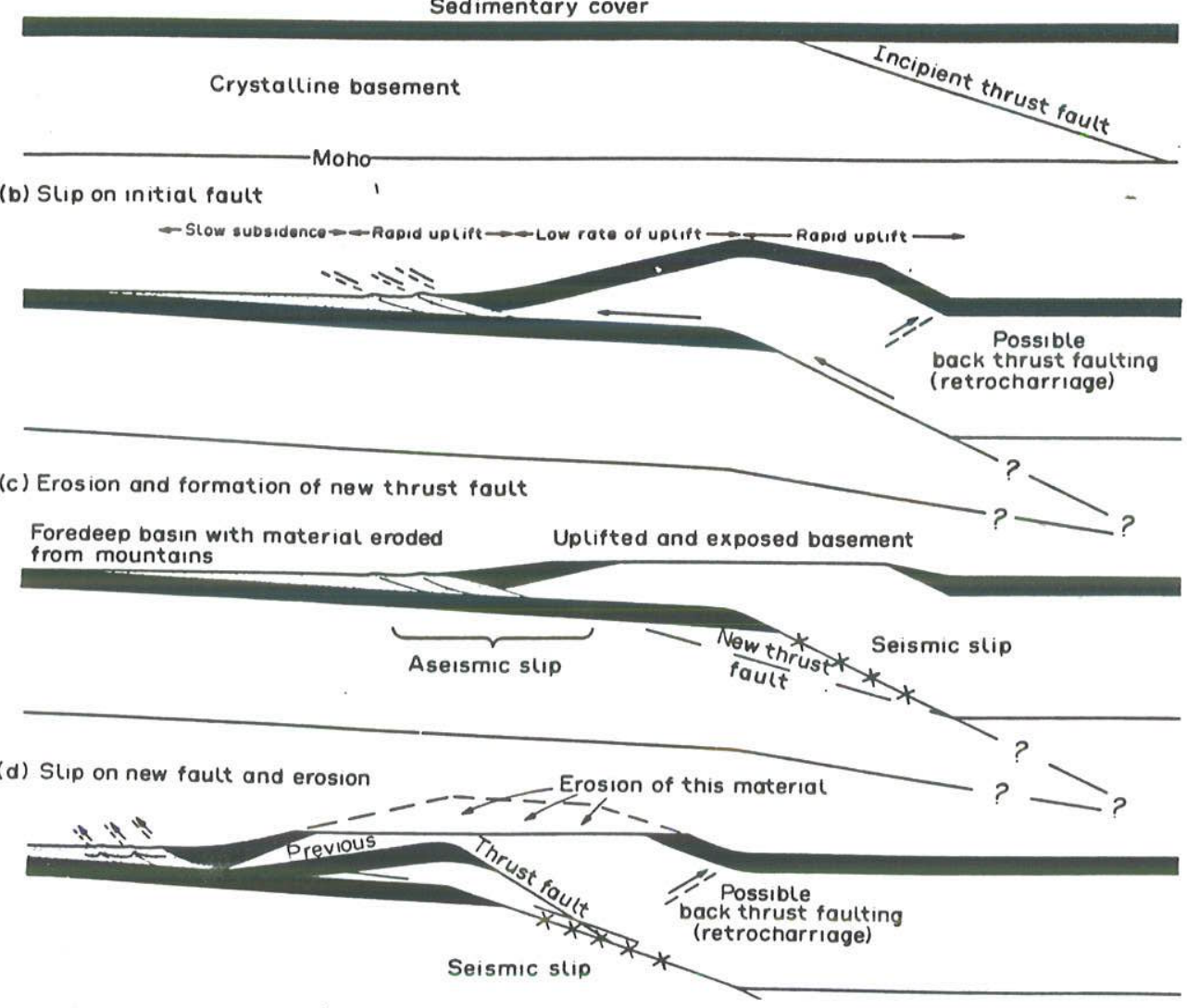

Figura 6.6 - A: ilustra "FalhasTranscorrentes Indentadas" e sua colocação tectônica (Woodcock \& Schubert, 1994 )e B: são esboços de falhas de overthurst em escala regional. Uma situação semelhante pode ser responsável pela geometria estrutural desenvolvida na área de estudo. 
Capítulo 7 


\section{Capítulo 7: Conclusões}

Baseado nos dados apresentados e nas informações obtidas na literatura podemos concluir que:

આ Devido à foliação bem desenvolvida paralela à foliação regional, a geometria sheet do plúton paralela à foliação regional, sua heterogeneidade composicional e o fabric recristalizado, um caráter sintectônico é atribuído ao Granito Guecá com forte componente compressional nos estágios finais de sua colocação e sua origem relacionada a fusão parcial associada ao processo de migmatização.

$\checkmark$ Para a colocação sintectônica do Granito Pico do Papagaio as evidências não estão claras. A única relação clara é que não se trata de um plúton pós tectônico o que é evidenciado pela larga zona milonítica ao longo da Zona de Cisalhamento Bairro do Alto.

$\checkmark$ A assembléia mineralógica sugere que os granitos Guaecá e Pico do Papagaio têm origens diferentes. O granito Pico do Papagaio apresenta afinidade do tipo I, enquanto que o Granito Guaecá, do tipo S.

$\mathscr{L}$ A associação de granitos do tipo I e S no mesmo evento tectônico sugere que eles se formaram durante uma colisão continental em um modelo próximo ao tipo Hercínico.

Metamorfismo em fácies anfibolito alto e homogêneo em toda área de estudo, com retrometamorfismo em fácies xisto verde.

\& Lineações dip-slip encontradas ao longo da Zona de Cisalhamento Camburu podem indicar altas taxas de strain, alto grau de partição do cisalhamento simples com predominância local do componente de cisalhamento puro. 
Alto strain e temperaturas altas envolvidas na deformação também são indicadas pela ocorrência de porfiroclastos, e fabric com alta recristalização como o Striped Gneiss, na Zona de Cisalhamento Bairro do Alto.

$\checkmark$ Na região que engloba o município de São Sebastião a formação de uma estrutura em flor positiva assimétrica é uma modelo satisfatório para o arranjo geométrico das estruturas locais.

$\checkmark$ Esta geometria também poderia ter se formado a partir de um modelo que inclui a ocorrência de sistemas de cavalgamento seguido por escape lateral com Falhas Transcorrentes Indentadas e um Back-... Thrust.

$\checkmark$ A deformação da área de estudo caracteriza-se um regime transpressivo heterogêneo, com heterogeneidade da deformação, alto strain causando partição da deformação.

Esta zona transpressiva assemelha-se ao modelo de Transpressão Dominada por Transcorrência (Wrench - Dominated Transpression), associada a baixo ângulo e oblíquidade de convergência. 
Capítulo 8 


\section{Capítulo 8: Re Rerências Bỉbliogrảinicas}

ALMEIDA, F. F, M. et al. 1976. The Upper Precambrian of South America. Boletim IG-USP, 7(1): 5-80.

ALMEIDA, F. F. M. et al. 1981. Texto explicativo. Mapa Geológico do Estado de São Paulo, 1:500.000. São Paulo, IPT. (monografia 6).

CAMPANHA, G. A. C.; ENS, H. H. 1993. Estrutura geológica na região de São Sebastião. In: SIMPÓSIO DE GEOLOGIA DO SUDESTE, 3, 1993. Bol. Res...Rio de Janeiro, SBG, p.51-52.

CAMPANHA, G.A.C.; ENS, H. H. 1996. Estruturação geológica da região da Serra do Juqueriquerê, São Sebastião, SP. Boletim IG-USP, Ser.Cient., 27: 4149.

CAMPANHA, G. A. C.; ENS, H. H.; PONÇANO, W.L. 1994. Análise morfotectônica do planalto do Juqueriquerê, São Sebastião. Revista Brasileira de Geociências, 24 (1): 32-42.

CAMPOS NETO, M. C. 1991. A porção ocidental da Faixa Alto Rio Grande ensaio de evolução tectônica. São Paulo. 210p. (Tese de Doutoramento Instituto de Geociências - Universidade de São Paulo).

CAMPOS NETO, M. C.; FIGUEIREDO, M. C. H. 1995. The Rio Doce orogeny, Southeastern Brazil. Jour.South.Amer.Eart.Scien., 8 (2): 143 - 162.

COBBOLD, P. R.; QUINQUIS, H. 1980. Development of sheath folds in shear regimes. Journal of Structural Geology, (2): 119-126. 
CONTI, J.B.; FURLAN, S. A. 1998. Geoecologia: o clima, os solos e a biota. In: ROSS, J. L. S. org. Geografia do Brasil. São Paulo, EDUSP. 549p.

CORDANI, U. G.; MELCHER, G. C.; ALMEDDA, F. F. M. 1968. Outline of the precambrian geochronology of South America. Can. J. Earth. Sci., 5, p.629 632.

CORREA NETO, A. V.; DAYAN, H.; VALENÇA, J. G.; CABRAL, A R. 1993. Geologia e estrutura do zona de cisalhamento do rio Paraiba do Sul e adjacências, no trecho entre Três Rios (RJ) e Sapucaia (RJ). In: SIMPÓSIO DE GEOLOGIA DO SUDESTE, 3, 1993. Atas... Rio de Janeiro, p. 194-200.

COWARD, M. 1994. Continental Collision. In: Hancock, P.L. ed. Continental Deformation. Pergamon Press. 421p.

CPRM. 1990. Projeto Santa Isabel - Mogi das Cruzes - Mauá. São Paulo. 194p. (Relatório Final, SCTDE/PROMINÉRIO/CPRM).

CPRM/ DNPM. 1977. Projeto Santos - Iguape. Relatório Final - Geologia. São Paulo. v.l.

DRURY, S. A. 1993. Image Interpretation in Geology. 2 ed. Chapman \& Hall. $283 p$.

EBERT, H. 1968. Ocorrências da fácies granulítica no sul de Minas Gerais e em áreas adjacentes em dependências da estrutura orogênica: hipótese sobre sua origem. Anais da Academia Brasileira de Ciencias, 40: 215-229.

EBERT, H. D.; HASUI, Y.; SENA COSTA, J. B. 1991. O Carácter transpressivo do cinturão transcorrente Rio Paraíba do Sul. In: SIMPÓSIO NACIONAL DE ESTUDOS TECTÔNICOS, 3, 1991. Bol. Res...Rio Claro, p.139- 141. 
EBERT, H. D.; NEVES, M. A.; HASUI, Y.; SZATMARI, P.; AIRES, J, R. 1993. Evolução dos Cinturões de Cisalhamento entre os Blocos S. Paulo, Vitória e Brasilia através da Tectônica Colisional Obliqua: uma modelagem física. In: SIMPÓSIO NACIONAL DE ESTUDOS TECTONNICOS, 4, 1993. Anais...Belo Horizonte, p. $254-258$.

EBERT, H. D.; NEVES, M. A.; HUTTON, D. H. W.; GUERRA, M. 1995. Alojamento de rochas plutonicas em regimes transpressivos: uma modelagem Experimental. In: SIMPÓSIO NACIONAL DE ESTUDOS TECTÔNICOS, 5, 1995. Bol. Res...Gramado, p.19-22.

EBERT, H. D.; HASUI, Y. 1998. Transpressional tectonics and strain partitioning during oblique collision between three plates in the Precambrian of south-east Brazil. In: HOLDSWORTH, R.E.STRACHAN, R. A. \& DEWEY, J.F. ed. Continental Transpressional and Transtensional Tectonics. London, Geological Society, Special Publication, n.135, p.231-252.

ENDO, I.; MACHADO, R. 1993. Sistema de Cisalhamento Transatlântico: um modelo tectônico transpressional para o Neoproterozóico do Brasil Oriental. In: SIMPÓSIO NACIONAL DE ESTUDOS TECTÔNICOS, 4, 1993. Anaiś...Belo Horizonte, p. $356-359$.

FASSBINDER, E. 1996. A formação Água Clara no contexto do Grupo Açungui: um modelo transpressivo de colisão oblíqua no Neoproterozóico paranaense. São Paulo. 207p. (Tese de Doutoramento - Instituto de Geociências, Universidade de São Paulo).

FIGUEIREDO, M. H; CAMPOS NETO, M. C. 1993. Geochemistry of the Rio Doce magmatic arc, Southeastern Brazil. Anais da Academia Brasileira de Ciências, 65 (1): 63-81. 
FYFE, W.S. \& LEONARDOS, O. H., JR 1974. Ancient metamorphic migmatite belts of the Brazilian Atlantic Coast. The african connection. Revista Brasileira de Geociências, 4: 247-251.

FRAGOSO CESAR, A. R. S. 1993. As placas brasilianas do sul e sudeste da Plataforma Sul - Americana. In: SIMPÓSIO NACIONAL DE ESTUDOS TECTÔNICOS, 4, 1993. Anais... Belo Horizonte, p.183 - 188.

FRETTAS, R. O. 1976. Definição petrológica, estrutural e geotectônica das cintas antigas do litoral norte do Estado de São Paulo. Boletim do Instituto Geológico, (1): 1-176.

GARDA, G. M.; SCHORSCHER, H. D. 1994. Os diques máficos e ultramáficos da região costeira entre São Sebastião e Ubatuba, São Paulo - SP. In: CONGRESSO BRASILEIRO DE GEOLOGIA, 38, 1994. Boletim de resumos...Camboriu, SBG, v. 3, p.62-63.

GARDA, G.M. 1995. Os diques básicos e ultrabásicos da região costeira entre as cidades de São Sebastião e Ubatuba, Estado de São Paulo. São Paulo. 156p. (Tese de doutoramento, Instituto de Geociências da Universidade de São Paulo).

HARLAND, W. B. 1971. Tectonic Transpression in Caledonian Spitzbergen. Geol. Mag. 108, 27-42. HASUY, Y.; CARNEIRO, C.D.R.; COIMBRA, A. M. 1975. The Ribeira Folded Belt. Revista Brasileira de Geociências, 5 (4): 257.266.

HASUY, Y. et al. 1978. Geologia da regiäo Administrativa 3 (Vale do Paraíba) e parte da região Administrativa 2 (Litoral). São Paulo, IPT. (monografia 1).

HASUI, Y.; HARALYI, N. L. E.; GALLI, V. A.; MIOTO, J. A. 1991. Estruturação Pré - Cambriana do Estado de São Paulo com base em dados geofísicos. In: 
SIMPÓSIO NACIONAL DE ESTUDOS TECTÔNICOS, 3, 1991. Anais...Rio Claro, p.137- 138 .

HASUI, Y.; MIOTO, J. M.; MORALES, 1994. Geologia do Pré - Cambriano. In: FALCONI, F. F; NEGRO JR. A. org. Solos do Litoral do Estado de São Paulo. Fapesp/ ABMS. 316p.

HASUI, Y.; SADOWSKI, G. R. 1976. Evolução geológica do Precambriano na região sudeste do Estado de São Paulo. Revista Brasileira de Geociências, 6: $182-200$.

HEILBRON, M.; VALERIANO, C.; VALLADARES, C.; MACHADO, N.; ALMEIDA, J. C. H.; TUPINAMBA, M.; DUARTE, B. P. 1996. The Brasiliano Orogeny (590-520 Ma.) at the central segment of Ribeira belt, SE Brazil. In: CONGRESSO BRASILEIRO DE GEOLOGIA, 39, 1996. Anais...Salvador, SBG, v.6, p.107-109.

INSTITUTO DE PESQUISA TECNOLOGICA DO ESTADO DE SAO PAULO IPT. 1992. Relatório Interno. São Paulo. 15p. (n.29.991).

INSTITUTO GEOLÓGICO - IG / SMA. 1996. Carta de Risco a Movimentos de Massa e Inundação do Município de São Sebastião - Mapa Geológico, escala 1:50.000. Relatório Interno.

JONES, R. R.; TANNER, W. G. 1995. Strain partitioning in transpression zones. Journal of Structural Geology, 17(6): 793-802.

KARLSTROM, K. E.; WILLIAMS, M. L. 1995. The case for simultaneous deformation, metamorphism and plutonism: an example from Proterozoic rocks in central Arizona. Journal of Structural Geology, 17(1): 59-81. 
LULLESAND, T. M.; KIEFER, R. W. 1994. Remote Sensing and Image Interpretation. 3 ed. John Wiley \& Sons, 750p.

LOCKZY, L; LADEIRA, E. A. 1976. Geologia Estrutural e Introdução à Geotectônica. Ed. Edgard Blucher, Rio de Janeiro, 528p.

LOPES, A.; NEZRY, E.; TOUZI, R.; LAUR, H. 1993. Structure detection and statistical adaptive speckle filtering in SAR images. Intern.Jour.Rem.Sens., 14 (9): $1735-1758$.

MACHADO, R. 1990. Batólito Serra dos Órgãos: uma entidade plutônica cálcio alcalina sin-colisional de arco magmático brasiliano do cinturão Ribeira no Rio de Janeiro. In: CONGRESSO BRASILEIRO DE GEOLOGIA, 36, Natal, 1990. Boletim de resumos...Natal, SBG, p.221.

MACHADO, R. 1996. Classificação tectônica de granitos. Unpublished paper.

MACHADO. R. 1997. Litogeoquímica e Tectônica dos granitóides Neoproterozóicos do Cinturão Paraíba do Sul no Estado do Rio de Janeiro. São Paulo. 215p. (Tese de Livre - Docencia, Instituto de Geociências Universidade de São Paulo).

MACHADO, R.; DEMANGE, M. 1991. Contexto tectônico e estrutural dos granitóides brasilianos do Estado do Rio de Janeiro. In: SIMPÓSIO NACIONAL DE ESTUDOS TECTÔNICOS, 3, 1991. Boletim de resumos ...Rio Claro, p. $64-65$.

MACHADO, R.; ENDO, I .1993. A Megaestrutura em flor positiva do vale do rio Paraiba do Sul no Rio de Janeiro e suas implicações tectônicas regionais. In: SIMPÓSIO DE GEOLOGIA DO SUDESTE, 3, 1993. Atas...Rio de Janeiro, p. $208-213$. 
MELO, M. S.; PIRES NETO, A. G. 1977. Esboço geológico da província costeira entre as serras do Juqueriquerê e Parati, Estado de São Paulo. In: SIMPÓSIO DE GEOLOGIA REGIONAL, 1, 1977. Atas...São Paulo, p.303- 323.

MERLE, O; GASPAIS, D. 1997. Strain within thrust -- wrench zones. Journal of Structural Geology, 19(7): 1011 - 1014.

MIOTO, J. A.; HASUI, Y. 1993. A Zona Sismogênica de Santos. In: SIMPÓSIO NACIONAL DE ESTUDOS TECTÔNICOS, 4, 1993. Anais...Belo Horizonte, v. 12, p. $302-305$.

MOLYNEAUX, S. J.; EBERT, H. D. 1997. The emplacement of extension related granites during regional transpression;some examples from São Paulo state, SE Brazil. In: CONT. TRANSP. TRANST. TECT. INTERN. CONFER., 1997. Abstracts...London.

NUMMER, A. R. 1996. Ascensão e colocação de granitos em zonas de cisalhamento dúcteis transcorrentes: abordagem cinemática. Unpublished paper.

PASSCHIER, C. W.; MYERS, J. S.; KRÖNER, A. 1993. Geologia de Campo de Terrenos Gnáissicos de Alto Grau. Trad. FIGUEIREDO, M.H. Edusp. São Paulo. 188p.

PASSCHIER, C. W.; TROUW, R. A. J. 1996. Microtectonics. Berlin, SprigerVerlag, 289p.

PATERSON, S. R.; FOWLER, T.K. 1993. Re-examining pluton emplacement processes. Journal of Structural Geology, 15: 191-206.

PITCHER, W.S. 1982. Granite type and tectonic environment. In: HSU, K. J. ed. Moutain Building Processes. Academic Press: 19-40. 
POHL, C. 1996. Geometric Aspects of Multisensor Image Fusion for Topographic Map Updating in Humid Tropics. ITC publication. (39). 159p.

PONÇANO, W. L.; CARNEIRO, C. D. R.; BISTRICHI, C. A.; ALMEIDA, F. F. M.; PRNADINI, F. L. 1981. Mapa Geomorfológico do Estado de São Paulo, 1:1.000.000. São Paulo, IPT. (monografia 1).

RAMSAY, J.G.; GRAHAM, R.H. 1970. Strain variation in shear belts. Canadian Journal of Earth Science 7: 786-813.

RICHARD, P.; COBBOLD, P. 1990. Experimental insights into partitioning of faults motions in continental convergent wrench zones. Ann. Tect. 6: 35-44.

ROBIN, P. Y. F.; CRUDEN, A. R. 1994. Strain and vorticity patterns in ideally ductile transpression zones. Journal of Structural Geology, 16 (4): 447 - 466.

SADOWSKI, G. R. 1974. A Tectônica da Serra de Cubatão, SP. São Paulo. (Tese de doutoramento, Instituto de Geociências da Universidade São Paulo).

SADOWSKI, G. R. 1983. Sobre a Geologia Estrutural de Cinturões de Cisalhamento Continentais. São Paulo. 108p. (Tese de Livre Docência, Instituto de Geociências da Universidade de São Paulo).

SANDERSON, D. J; MARCHINI, W. R. D. 1984. Transpression. Journal of Structural Geology, 6(5): 449-458.

SCHETSELAAR, E. M.; McDONOUGH, M. R. 1996. Shear zone mapping using ERS-1 images of the Paleoproterozoic Taltson magmatic zone, Canadian Sheid, northeastem Alberta. ITC Jounal, 2: 166 - 175.

SHELLEY, D. 1993. Igneous and metamorphic rocks under the microscope. Chapman \& Hall. 
SIBSON, R. H. 1977. Fault Rocks and Fault Mechanisms. J.Geol.Soc. London. (133): 191-213.

TASSINARI, C. C. G. 1988. As idades das rochas e dos eventos metamórficos da porção sudeste do Estado de São Paulo e sua evolução crustal. São Paulo. 236p. ( Tese de Doutoramento, Instituto de Geociências da Universidade de São Paulo).

TEYSSIER, C.; TIKOFF, B. 1999. Fabric stability in oblique convergence and divergence. Journal of Structural Geology, 21: 969-974.

THOMPSON, A. B.; JESEK, J.; SCHULMANN, K. 1997. Metamorphic facies and strain facies in convergent to transpressive weak zones. In: CONT. TRANSP. TRANST. TECT. INTERN. CONFER., 1997. Abstracts...London.

TIKOFF, B.; GREENE, D. 1997. Stretching lineations in transpressional shear zones: an example from Sierra nevada Batholith, Califomia. Journal of Structural Geology, 19 (1): 29-39.

TIKOFF, B; TEYSSIER, C. 1994. Strain modeling of displacement field partitioning in transpressional orogens. Journal of Structural Geology, 16: 1575- 1588 .

TOMINAGA, L. K. 1995. Contribuição da Geomorfologia à Cartografia de Risco a Escorregamentos do Município de São Sebastião - SP. In: SIMPÓSIO NACIONAL DE GEOGRAFIA FÍSICA APLICADA, 6, 1995. Anais..., v.1, p. $251-256$.

TWISS, R. J.; MOORES, E. M.1992. Structural Geology. Freeman, New York. VAUCHEZ, A.; TOMMASI, A.; EGYDIO-SILVA, M. 1994. Self-indentation of a heterogeneous continental lithosphere. Geology, 22 (9): 967- 970. 
WERNICK, E. \& TÖPFNER, C. 1997. Idades do Magmatismo Granitóide Brasiliano nos Estados de Sâo Paulo e Minas Gerais: implicações na caracterização temporal da evolução do Cinturão Ribeira. In: SIMPÓSIO DE GEOLOGIA DO SUDESTE, 5, 1997. Boletim de Resumos, $159-161$.

WERNICK, E. 1990. Zoneamento magmático regional de granitóides brasilianos no sudeste/sul do Brasil: implicações geotectônicas. In: CONGRESSO BRASILEIRO DE GEOLOGIA, 36, 1990. Anais... Natal, SBG, 4, p.16681683.

WIEDEMANN, C; LAMMERER, B.; MENDES, J. C.,; LUDKA, 1. P. 1996. The Evolution of the Brasiliano/Panafrican mobile belt along the central part of brazilian coast (Espirito Santo). In: CONGRESSO BRASILEIRO DE GEOLOGIA, 39, 1996. Anais...Salvador, v.6, p.

WOODCOCK, N. H.; SCHUBERT, C. 1994. Continental Strike-Slip Tectonics. In: HANCOCK, P. L. ed. Continental Deformation. Pergamon Press. $421 \mathrm{p}$.

YARDLEY, B. W. D. 1989. An introduction to metamorphic petrology. Longman. London. 248p. 


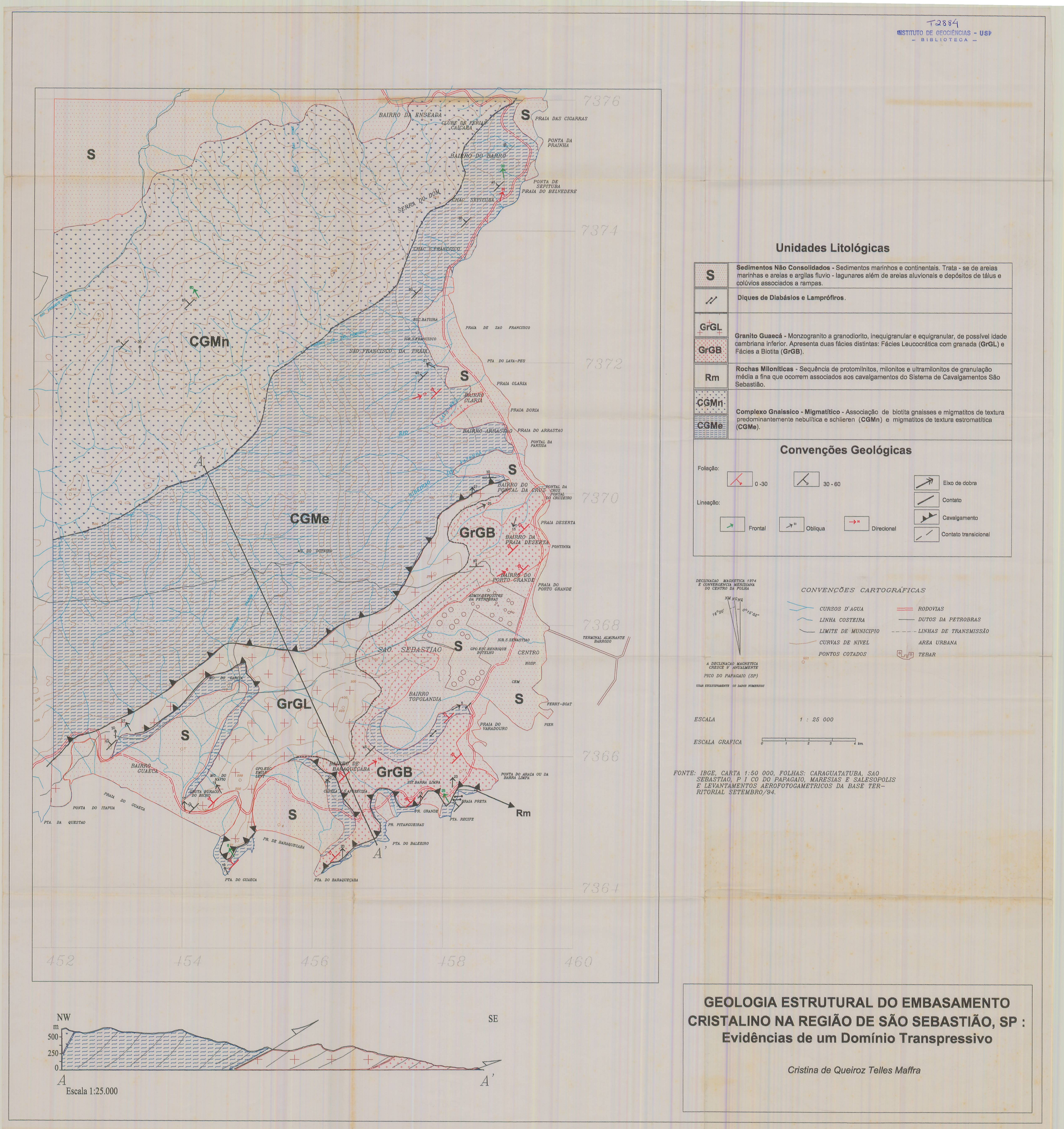

